UNIVERSIDADE DE SÃO PAULO

ESCOLA DE ARTES, CIÊNCIAS E HUMANIDADES

PROGRAMA DE PÓS-GRADUAÇÃO EM ESTUDOS CULTURAIS

MARIA ESTELA SILVA ANDRADE

O ensaio desenvolvimentista no cinema brasileiro de ficção científica

São Paulo

2019 


\title{
O ensaio desenvolvimentista no cinema brasileiro de ficção científica
}

\author{
Versão corrigida
}

Dissertação apresentada à Escola de Artes, Ciências e Humanidades da Universidade de São Paulo para obtenção do título de Mestre em Filosofia pelo Programa de Pós-graduação em Estudos Culturais.

Versão corrigida contendo as alterações solicitadas pela comissão julgadora em 31 de maio de 2019. A versão original encontra-se em acervo reservado na Biblioteca da $\mathrm{EACH} /$ USP e na Biblioteca Digital de Teses e Dissertações da USP (BDTD), de acordo com a Resolução CoPGr 6018, de 13 de outubro de 2011.

Área de Concentração:

Estudos Culturais

Orientador:

Prof. Dr. Luís Paulo de Carvalho Piassi 
Autorizo a reprodução e divulgação total ou parcial deste trabalho, por qualquer meio convencional ou eletrônico, para fins de estudo e pesquisa, desde que citada a fonte.

Andrade, Maria Estela Silva

O ensaio desenvolvimentista no cinema brasileiro de ficção científica / Maria Estela Silva Andrade ; orientador, Luís Paulo de Carvalho Piassi. - 2019.

$89 \mathrm{f.}$ : il.

Dissertação (Mestrado em Filosofia) - Programa de PósGraduação em Estudos Culturais, Escola de Artes, Ciências e Humanidades, Universidade de São Paulo, São Paulo.

Versão corrigida

1. Cinema - Brasil - Análise do discurso. 2. Semiótica. 3. Ficção científica (Gênero) - Brasil. 4. Desenvolvimento econômico - Brasil. 5. Desenvolvimento cultural - Brasil. 6. O homem do futuro (Filme). 7. Branco sai, preto fica (Filme). I. Piassi, Luís Paulo de Carvalho, orient. II. Título. 
Nome: ANDRADE, Maria Estela Silva

Título: O ensaio desenvolvimentista no cinema brasileiro de ficção científica

Dissertação apresentada à Escola de Artes, Ciências e Humanidades da Universidade de São Paulo para obtenção do título de Mestre em Filosofia do Programa de Pós-Graduação em Estudos Culturais.

Área de Concentração:

Estudos Culturais

Aprovado em: $31 / 05 / 2019$

\section{Banca Examinadora}

Prof. Dr. Alice Pierson

Julgamento: Aprovada

Prof. Dr. Elizabeth Harkot de La Taille

Julgamento: Aprovada

Prof. Dr. Emerson Ferreira Gomes

Julgamento: Aprovada
Instituição: Universidade Federal de São

Carlos

Assinatura:

Instituição: Universidade de São Paulo

Assinatura:

Instituição: Universidade de São Paulo Assinatura: 
Dedico esta dissertação aos meus pais, ao Luck e a todas e todos pesquisadores brasileiros que resistem. 


\section{Agradecimentos}

Agradeço à minha família, amigas e amigos por todo o apoio ao longo dessa jornada;

Ao Luís Paulo Piassi por toda ajuda e paciência;

À Coordenação de Aperfeiçoamento de Pessoal de Nível Superior (CAPES), que financiou esta pesquisa - código de financiamento 001;

À Universidade de São Paulo e seus funcionários e funcionárias por me proporcionarem toda infraestrutura necessária. 
"Da nossa memória fabulamos 'nóis' mesmos."

(QUEIRÓS, 2014) 


\section{RESUMO}

ANDRADE, Maria Estela Silva. O ensaio desenvolvimentista no cinema brasileiro de ficção científica. 2019. 89 f. Dissertação (Mestrado em Filosofia) - Escola de Artes, Ciências e Humanidades, Universidade de São Paulo, São Paulo, 2019. Versão corrigida.

Desde o início da colonização europeia, o Brasil sustenta no imaginário popular o rótulo de país do futuro. Tal mito tem sido reciclado através dos séculos de acordo com os contextos históricos, de forma que no século XX ajudou a levantar as bandeiras desenvolvimentistas dos governos de Getúlio Vargas e da ditadura militar. Após cair no ostracismo nas décadas de 1980 e 1990, foi trazido novamente à tona no início dos anos 2000 ao longo das gestões petistas, alinhado a uma política econômica identificada como ensaio desenvolvimentista. Tendo em vista que a cultura da mídia influencia e é influenciada por aspectos sociais, dentre eles a política institucional, e que a ficção científica é um gênero que narrativo que mobiliza a percepção das mais diversas características sociais, analisamos como o cinema brasileiro de ficção científica absorveu e propagou o mito do país do futuro durante os anos de governo do Partido dos Trabalhadores. Para isso, selecionamos dois filmes do período com formas de produção e distribuição distintas, são eles: O Homem do Futuro (TORRES, 2011) e Branco Sai, Preto Fica (QUEIRÓS, 2014). Ademais, nos valemos da semiótica de Greimas e dos Estudos Culturais como métodos de análise do material selecionado. Por fim, chegamos a um resultado que indica que os filmes têm visões opostas acerca do mito em questão, e que essas são influenciadas por abordagens distintas acerca da interação entre raça e classe social.

Palavras-chave: Ficção científica. Desenvolvimentismo. Estudos Culturais. Semiótica. Cinema. 


\begin{abstract}
ANDRADE, Maria Estela Silva. The developmental essay in brazilian science fiction cinema. 89 p. Dissertation (Master of Philosophy) - School of Arts, Sciences and Humanities, University of São Paulo, São Paulo, 2019. Corrected version.

Since the beginning of the European colonization, Brazil holds in popular imagination the label of country of the future. This mythology has been recycled through the years according to historical contexts, so that in twentieth century was implemented as doctrine on Getúlio Vargas and the military dictatorship's governments. Forgotten for two decades, the early 2000s brought it back along PT's administrations, in line with an economic policy identified as "developmental essay". Given that media culture influences and is influenced by social aspects, including institutional policy, and that science fiction is a narrative gender that mobilizes perceptions on social, we tried to analyze here how brazilian science fiction movies absorved and propagated the "country of the future" myth during the years of Workers' Party government. To that end, we selected two films from the period with distinct production and distribution: The Man of the Future (TORRES, 2011) and Branco Sai, Preto Fica (QUEIRÓS, 2014). In addition, we used french semiotics and Cultural Studies as methods to analyze the selected material. We came to a result that indicates the films have different visions on the issue of the myth in question, and that these are influenced by the distinct approaches on the interaction between race and social class.
\end{abstract}

Keywords: Science fiction. Developmentalism. Cultural studies. Semiotics. Cinema. 


\section{LISTA DE FIGURAS}

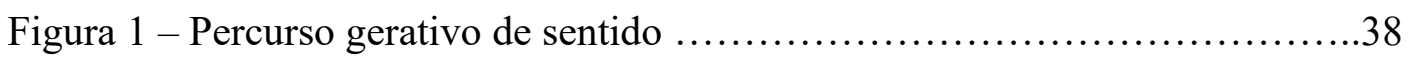

Figura 2 - Capa da revista The Economist (2009)............................46

Figura 3 - Capa da revista The Economist (2013)...........................48

Figura 4 - Capa da revista The Economist (2016) .............................49

Figura 5 - Percurso narrativo de Zero ....................................52

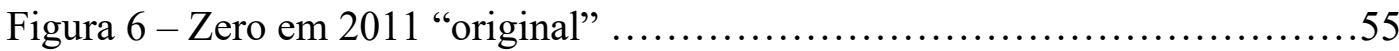

Figura 7 - João com Helena, antes de tornar-se Zero, em 1991 ...................56

Figura 8 - Sandra e Zero discutem no laboratório.............................56

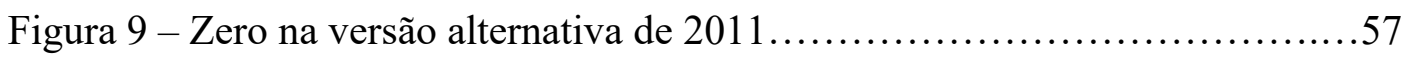

Figura 10 - Zero, ao sair da corte, com Panda e Helena..........................57

Figura 11 - Gráfico Inflação x Desemprego no Brasil - 1991 a 1995 ...............59

Figura 12 - Gráfico Inflação x Desemprego no Brasil - 1996 a 2002 ............60

Figura 13 - Gráfico Inflação x Desemprego no Brasil - 2002 a 2016............61

Figura 14 - Percurso narrativo de Marquim..................................71

Figura 15 - Marquim em seu bunker ........................................ 72

Figura 16 - Sartana na varanda de sua casa...............................72

Figura 17 - Dimas ao quebrar a quarta parede............................... 74 


\section{LISTA DE QUADROS}

Quadro 1 - Etapas do Percurso Gerativo de Sentido............................37

Quadro 2 - Disposição das Personagens em O Homem do Futuro.................51

Quadro 3 - Disposição dos Elementos no Percurso de Zero.......................54 


\section{SUMÁRIO}

1 INTRODUÇÃO 12

2 A FICÇÃO CIENTÍFICA

2.1. Pós-Modernidade e Utopia em Fredric Jameson 21

2.2. A Ficção Científica no Brasil 24

2.3. Panorama do Cinema Brasileiro de Ficção Científica 29

3 METODOLOGIA 33

3.1. Semiótica de Greimas 35

3.2. Seleção do Corpus 38

4 BRASIL, O PAÍS DO FUTURO 41

4.1. Governos Lula e Dilma Rousseff 44

5 ANÁLISES

5.1. O Homem do Futuro 50

5.1.1. Análise de O Homem do Futuro 50

5.2. Branco Sai, Preto Fica 65

5.2.1. Análise de Branco Sai, Preto Fica 66

6 CONSIDERAÇÕES FINAIS

REFERÊNCIAS 


\section{INTRODUÇÃO}

Desde os primórdios da colonização brasileira pelos europeus, um ideal vem sendo cultivado: a convicção de que o Brasil é predestinado à grandeza - discurso presente desde o surgimento do mito da terra edênica, já presente na carta de Pero Vaz de Caminha ao rei de Portugal ${ }^{1}$, até às expectativas de crescimento econômico nos séculos XX e XXI.

Se no início eramos o paraíso perdido, logo passamos a ser a terra em que tudo dá e a menina dos olhos do capitalismo mercantil ao abrigarmos os avançados engenhos de cana-de-açúcar, num processo de produção e distribuição que ao aglutinar três de quatro continentes, permitiu aos povos ibéricos criar a primeira economia de âmbito mundial (RIBEIRO, 1995). Contudo, a passagem do sistema mercantil ao capitalista não permitiu que uma nação agroexportadora sustentasse o ideal de progresso, tornando-se necessário investir na industrialização do país.

De acordo com o pesquisador e professor da área econômica, Pedro Fonseca (2004), foi a partir da década de 1950, nos governos Vargas e Kubitscheck, que políticas desenvolvimentistas passaram a ser adotadas no Brasil. Tendo atingido seu auge no século XX durante o período da ditadura militar - o milagre brasileiro -, o discurso em prol do avanço caiu no ostracismo nas décadas de 1980 e 1990, para voltar à cena renovado nos anos 2000.

Acreditamos que nos primeiros anos de governo petista, a melhora em indicadores econômicos e sociais - crescimento médio do Produto Interno Bruto (PIB) brasileiro em 4\% ao ano e inflação controlada com taxa anual média de 5,4\% (CRUZ et al, 2012), aumento de investimentos em projetos sociais por parte do governo federal, extensão do programa Bolsa Família, queda na taxa de desemprego e forte expansão do crédito (FONSECA, CUNHA e BICHARA, 2013) - além da presença marcante do Brasil no cenário político internacional - Conferência do Clima e atuação militar no Haiti - e em grandes eventos midiáticos internacionais - conquista da sede da Copa do Mundo de futebol de 2014 e das Olimpíadas de 2016 -, associadas à figura de um líder carismático, intensificaram uma estrutura de sentimento ${ }^{2}$ que reforçou o imaginário nacional mitológico de que o Brasil era digno de um lugar entre os grandes.

No cinema, o terreno começou a ser preparado um pouco antes como consequência de um fenômeno ocorrido em grande parte da América Latina, sobretudo no Brasil ${ }^{3}$, na Argentina e no México, com o estabelecimento de regimes democráticos que desenvolveram políticas culturais de

1 A transcrição da carta feita pela Biblioteca Nacional pode ser acessada por meio do link em:

$<$ http://objdigital.bn.br/Acervo_Digital/livros_eletronicos/carta.pdf >. Acesso em 17 jun 2019.

2 Estrutura de sentimento é o termo cunhado por Raymond Williams que, na definição de Maria Elisa Cevasco (2001, p. 158), é: "uma resposta a mudanças determinadas na organização social, é a articulação do emergente, do que escapa da força acachapante da hegemonia, que certamente trabalha sobre o emergente nos processos de incorporação".

3 No Brasil, a retomada do cinema se deu após do governo Collor (1990-1992), sendo que Carlota Joaquina, a princesa do Brasil, longa-metragem de Carla Camurati que marca a fase, foi lançado em 1995. 
incentivo ao cinema (NAGIB, 2006). De acordo com Lúcia Nagib, essa fase é marcada por: “[...] uma euforia que refletia o retorno da crença no Brasil como um país viável, o gesto utópico perdido no passado do cinema novo, retornou com novo ímpeto, particularmente notável nos primeiros anos da reforma neoliberal do governo Fernando Henrique Cardoso" (NAGIB, 2006, p. 17).

No entanto, segundo André Singer, com mudanças na política econômica a partir de 2013, “o desenvolvimentismo oferece resistência surda, porém crescentemente enfraquecida, à pressão em favor do choque neoliberal"(SINGER, 2015, p. 54). No mesmo ano, uma onda de manifestações populares tomou conta das ruas brasileiras. Mesmo que seu mote inicial fosse a reivindicação contra o reajuste das tarifas dos transportes públicos, esse expandiu-se para outras demandas e junto à intensificação da crise econômica internacional serviu como desacelerador ao ritmo de crescimento do país. Menos de três anos após as jornadas de junho de 2013, o país atingiu uma crise política que culminou com o impeachment da presidenta petista Dilma Rousseff. O mito da grande nação tornou-se insustentável.

Mesmo que a esperança em se tornar o país do futuro ${ }^{4}$ tenha sido novamente adiada, não descartamos a importância de sua propagação e de seus reflexos na sociedade brasileira, pois concordamos com Douglas Kellner $(2001 ; 2003 ; 2016)$ acerca do auxílio que espetáculos midiáticos fornecem à composição de narrativas do cotidiano, de forma que modelam opiniões políticas, comportamentos sociais e proporcionam materiais para a construção de identidades individuais. Kellner também afirma que a cultura veiculada pela mídia:

[...] fornece o material com que muitas pessoas constroem o seu senso de classe, de etnia e raça, de nacionalidade e de sexualidade, de 'nós' e 'eles'. Ajuda a modelar a visão prevalecente de mundo e os valores mais profundos: define o que é considerado bom ou mau, positivo ou negativo, moral ou imoral. As narrativas e as imagens veiculadas pela mídia fornecem os símbolos, os mitos e os recursos que ajudam a constituir uma cultura comum para a maioria dos indivíduos [...]. (KELLNER, 2001, p. 9)

Sob essa perspectiva, nos propomos nesta dissertação a analisar como o cinema brasileiro absorveu e propagou o mito do país do futuro durante os anos de governo do Partido dos Trabalhadores (PT). Para isso, selecionamos dois filmes do período com formas de produção e distribuição distintas e com características do gênero fícção científica, são eles: O Homem do Futuro (TORRES, 2011) e Branco Sai, Preto Fica (QUEIRÓS, 2014).

Ainda inspirados por Kellner, utilizaremos o conceito "cultura da mídia” (KELLNER, 2001) para designar a instituição produtora e a forma de produção de nossos objetos de estudo. $\mathrm{O}$ termo

4 Diferente de Stefan Zweig (2001) que utiliza a expressão "país do futuro" para indicar um Brasil de suposta harmonia racial e pacificidade, utilizamos aqui o mesmo termo como referência à expectativa de crescimento científico, tecnológico e econômico que, no imaginário coletivo, o Brasil algum dia irá alcançar. 
escolhido faz referência a uma forma de produção industrial, voltada para as massas, de acordo com gêneros, fórmulas, códigos e normas padronizadas (Ibid.). Segundo Kellner (2001, p. 9), essa dinâmica produz:

[...] uma forma de cultura comercial e seus produtos são mercadorias que tentam atrair o lucro privado produzido por empresas gigantescas que estão interessadas na acumulação de capital. A cultura da mídia almeja grande audiência; por isso deve ser eco de preocupações atuais, sendo extremamente tópica e apresentando dados hieroglíficos da vida social contemporânea.

De acordo com o estudioso, o termo ainda apresenta outras vantagens:

A expressão 'cultura da mídia' tem a vantagem de designar tanto a natureza quanto a forma das produções da indústria cultural (ou seja, a cultura) e seu modo de produção e distribuição (ou seja, tecnologias e indústrias da mídia). Com isso evitam-se termos ideológicos como 'cultura de massa' e 'cultura popular' e se chama a atenção para o circuito de produção, distribuição e recepção por meio do qual a cultura da mídia é produzida, distribuída e consumida. Essa expressão derruba as barreiras artificiais entre os campos dos estudos de cultura, mídia e comunicações e chama a atenção para a interconexão entre cultura e meios de comunicações na constituição da cultura da mídia, desfazendo assim distinções reificadas entre 'cultura' e 'comunicação'. (Ibid, p. $52)$.

Optamos por filmes de ficção científica (FC), pois, além de partes constituintes da cultura da mídia, apresentam a característica central de mobilizar questões acerca do futuro, tecnologias e de outras formas de vida e sociedades. Assim como constatou Ginway (2005a) em seu estudo sobre narrativas brasileiras ao longo dos anos da ditadura militar, as FC também nos parecem veículos ideais para a percepção de características do processo de modernização implantado no Brasil durante o período estudado por nós. Além disso, como veremos detalhadamente mais adiante, de acordo com alguns autores e autoras (SUVIN, 1984; JAMESON, 2005; MELZER, 2006), esse gênero, em específico, opera de forma particular com nossas indagações e desejos:

Essa tensão entre o 'conhecido' e o 'desconhecido' está no centro da ficção científica. Ela cria um processo de leitura baseado no estranhamento, que coloca questões familiares em território estranho: mesmo quando não estamos familiarizados com um novo planeta e sua correspondente tecnológica descrita, questões sociais e pessoais da narrativa falam sobre nossas experiências. Esse estranhamento também cria espaços de abstração para teorizarmos. (MELZER, 2006, p. 3, tradução nossa ${ }^{5}$ ).

Com isso, nosso trabalho se encontra estruturado da seguinte forma: damos início com um panorama da ficção científica, o qual passa por suas origens, características, subgêneros, ênfase nas

5 "This tension between the 'known' and the 'unknown' is at the heart of science fiction. It creates a reading process based on estrangement, which places familiar issues into strange territory: even when we are not familiar with a new planet and its corresponding new technology being described, the social and personal issues within the narrative speak to our experiences. This estrangement also creates spaces of abstraction for theorizing". 
utopias por meio do olhar de Fredric Jameson, e a história do gênero no Brasil. No segundo capítulo é apresentada em detalhes de nossa metodologia, composta pela união da semiótica de linha francesa com os Estudos Culturais. Seguimos com estudos sobre a política econômica adotada pelos governos petistas entre os anos de 2003 e 2013 e como essa ajudou a trazer de volta à cena o mito em questão. No capítulo quatro temos as apresentações dos filmes escolhidos e suas análises. Por fim, nossas considerações finais. 


\section{A FICÇÃO CIENTÍFICA}

Uma ficção que tenta prever o futuro ou histórias que tem em seu pano de fundo detalhes cientificamente comprovados? Especulação ou sonhos? Afinal, o que é ficção científica?

Muitas tem sido as tentativas de delimitar a categoria, desde definições que exigem a presença de conhecimentos científicos nas narrativas até mesmo algumas que a aproximam da fantasia ou a unem à ficção especulativa. Para uma compreensão inicial, partimos da citação de L. David Allen, presente em seu livro No Mundo da Ficção Científica (1974), que afirma: "Dizer que a ficção científica é distinguida de outras formas de ficção pela presença de algum tipo de ciência ou por extrair seu estímulo das ciências não esclarece o uso ficcional que é feito destes materiais"(ALLEN, 1974, p. 227). Ou seja, nem toda narrativa que inclua um artefato científico está apta a essa classificação. Sobre isso, o autor continua:

[...] é um ponto de vista particular ou um tratamento da ciência que está incluído na ficção científica. [...] a ciência em ficção científica não é a ciência corrente nem é aplicada numa situação corrente; antes é extrapolada, estendida além do estado corrente das ciências ou da situação corrente sob certos aspectos; isto é, o escritor parte do estado corrente das ciências e projeta o que parece ser um desenvolvimento lógico deste estado corrente do conhecimento. (Ibid, p. 225).

Allen (1974) também destaca que o que mais interessa à FC encontra-se na relação entre o ser humano e sua tecnologia ou entre seu universo, além de afirmar que tal gênero considera aspectos da vida humana de modo diferente de todas as outras formas literárias.

Quanto às características das ciências apresentadas na ficção científica, Umberto Eco (1989) chega a uma proposição semelhante à de Allen:

Temos science fiction como gênero autônomo quando a especulação contrafactual de um mundo estruturalmente possível é conduzida extrapolando, de algumas linhas de tendência do mundo real, a possibilidade mesma do mundo futurível. Ou seja, a ficção científica assume sempre a forma de uma antecipação, e a antecipação assume a forma de uma conjetura a partir de linhas de tendência reais do mundo real. (ECO, 1989, p. 169).

Para elucidar a antecipação a qual Eco se refere, temos o exemplo da trilogia Fundação, do escritor Isaac Asimov (1975), em que o autor cria a psico-história, uma hipótese a partir de dados reais, combinação entre elementos da psicologia, da história e da estatística para gerar 
uma nova técnica de análise social. Apesar da utilização dos termos "futurível" e "antecipação", Eco (1989) - e outros, como Jameson (2005) - explica que a FC não trata apenas do que está por vir, mas de alternativas à realidade.

Outro ponto importante é que a lógica científica desenvolvida é que deve subordinar-se à narrativa e não o contrário. Nesse sentido, talvez seja mais adequado o conceito de novum inovação histórica - descrito por Darko Suvin (1984), o qual representa qualquer elemento da diegese - engenho, personagem, local, etc - validado mediante à lógica cognoscitiva e que promova uma descontinuidade entre os mundos fictício e real, seja do/a autor/a ou do/a leitor/ a - espectador/a em nosso caso - implícito/a, como, por exemplo, as máquinas do tempo presentes nos dois filmes que serão aqui analisados. Para Suvin, é imprescindível a presença de tal lógica para caracterizar o gênero, mas isso não quer dizer que ela deva se provar científica e/ou metodologicamente possível em nosso mundo, mas deve ao menos ser baseada em cognições novas, imaginadas ou extrapoladas à realidade empírica do/a autor/a (SUVIN, 1984). Ele também explica que não é toda e qualquer novidade que corresponde a um novum:

Em primeiro lugar, o domínio ou a hegemonia da novidade cognitiva significa que a narração de ficção científica não é somente um relato no qual se inclua este ou aquele elemento de ficção científica [...]. Uma narrativa de fíç̧ão científica é uma ficção na qual o elemento de ficção científica, o novum, é hegemônico, ou seja, tão central e significante que determina toda a lógica da narrativa - ou ao menos a lógica preponderante do relato - independente das impurezas que possa apresentar. (SUVIN, 1979, p. 80, tradução nossa ${ }^{6}$ ).

Conceitualizado o novum, podemos perceber algumas características intrínsecas a ele e, por conseguinte, ao gênero, como a historicidade, pois sendo incomum não só ao ambiente físico mas também ao tempo histórico, o novum diz muito sobre a sociedade representada por que e como o novum foi reconhecido como novidade? O que é necessário para seu entendimento? O que ele requer? Quais seus horizontes? -, seja literalmente ou como sátira, mesmo que nem sempre a relação seja explícita. Outro aspecto é a aliança entre o estranhamento e a cognição para o desenrolar de acontecimentos em um ambiente empírico, já que a novidade se destaca por ser incomum ao meio em que é inserida; diferente da fantasia, do horror e do sobrenatural, gêneros muitas vezes tidos como próximos à $\mathrm{FC}$ mas que dispõem de leis anticognitivas que atuam no campo do metafísico (não há nesses gêneros

6 "First of all, the dominance or hegemony of the cognitive novelty means that an SF narration is not only a tale that includes this or that SF element [...]. An SF narration is a fiction in wich SF element or aspect, the novum, is hegemonic, that is só central and significant that it determines the whole narrative logic - or at least the overriding narrative logic - regardless of any impurities that might be present". 
uma preocupação científica em explicar cientificamente, por exemplo, como e porquê um boneco ganha vida e passa a matar pessoas).

Isso nos leva diretamente à questão da verossimilhança e da suspensão de incredulidade, ou seja, a capacidade de fazer com que o/a leitor/a ou espectador/a creia e se deixe levar pelo universo da história. Segundo Skorupa (2001), atribuir verossimilhança à FC é um caso particular, já que essa cria suas fabulações com referência em um discurso que, no imaginário popular, é carregado de seriedade por ser validado pelo método científico. Para ele:

\begin{abstract}
Muitos se enganam ao considerar que a verossimilhança da ficção científica ampara-se em uma suposta casualidade a partir da qual essa literatura um dia foi associada à ciência. [...] não se pode confundir o que tanto uma como a outra se propõe a oferecer. O caráter importante de verossimilhança não está prioritariamente no texto sob uma justificativa plausível e realista, em uma ou outra história, nesta ou naquela situação descrita com veracidade. Pode estar. Porém, a verossimilhança é um atributo presente no sentido geral do gênero, não pretende passar um pelo outro - ambos têm espaços definidos -, mas mimetizar, caricaturar e aparentar os procedimentos efetivos da ciência de modo que o apresentado assemelhe-se ao real, mesmo que seja de forma absurda. (SKORUPA, 2001, p. 69).
\end{abstract}

Dentre um universo de diversos autores/as e estudiosos/as da ficção científica, se olharmos apenas os aqui citados, já podemos ter ideia de que não existe uma definição fechada para o gênero, porém, com base nos mesmos, elaboramos um critério para a identificação de obras a ser utilizado nesta pesquisa, no qual a FC é compreendida como um gênero em que a verossimilhança é validada pela lógica cognoscitiva de uma ciência extrapolada ou não, e que apresenta algum tipo de inovação histórica fundamental para o desenvolvimento da narrativa.

Sobre a história do gênero, Arthur B. Evans (2009) diz que a ficção científica obteve seu nome e identidade social nas primeiras décadas do século $\mathrm{XX}$ nas revistas pulp americanas, porém, no século anterior, a categoria já se fazia presente na literatura. Segundo Stableford (2003), muitos historiadores modernos identificam em Frankenstein, ou o Moderno Prometeu, de Mary Shelley (1818), as origens do romance científico britânico, mesmo que suas influências não tenham sido sentidas instantaneamente e sua narrativa possa ser considerada anticientífica para os padrões cartesianos do século XVIII. Sobre isso, Evans diz:

Movendo a fonte do terror do sobrenatural para o científico, o romance gótico de Shelley exemplificou a rejeição romântica da crença cartesiana do século XVIII do cientista como herói e na tecnologia como inerentemente boa. 'Frankenstein' 
expressou os medos e o mal do século de toda uma geração presa no paradigma entre tradição e modernidade. Como tal, o romance provou ser altamente influente e popularizou o que viria a se tornar um arquétipo padrão da ficção científica do século XIX: o cientista louco que em sua árdua perseguição por conhecimento e poder trai valores humanos básicos. (EVANS, 2009, p. 13, tradução nossa ${ }^{7}$ ).

Ainda assim, de acordo com Evans (2009), há quem acredite que o nascimento do gênero se deu apenas algumas décadas mais tarde, após a consolidação da Revolução Industrial, com os romances A Volta ao Mundo em 80 Dias, de Julio Verne (1873), e A Máquina do Tempo, de H. G. Wells (1895). Independente do marco histórico, uma coisa é certa: “A explosão de narrativas de FC durante o século XIX pode ser entendida apenas no contexto histórico da Revolução Industrial e da transformação (e alienação) das mudanças sociais que a acompanharam" (EVANS, op. cit., p. 13, tradução nossa ${ }^{8}$ ). Ferramentas tecnológicas tornaram-se cada vez mais comuns no cotidiano e as inovações da tecnologia passaram a se dar numa velocidade nunca antes experimentada na História, o ritmo de vida aumentou e ocasionou novas percepções da realidade. Já para Stableford (2003) o conjunto da ação de 4 fatores de uma mesma época no imaginário popular, não necessariamente suas implicações concretas, foram preponderantes para o surgimento da FC: a) a revolução nos transportes; b) a teoria da evolução de Charles Darwin; c) o movimento socialista; d) o surgimento da guerra em larga escala. Tanto em uma hipótese quanto em outra, percebemos que as mudanças sociais e econômicas trazidas pela união do avanço científico ao capitalismo no século XVIII foram a principal causa para o nascimento da ficção científica, assim, não é de se espantar o surgimento do gênero na Era dos Impérios, segundo Adam Roberts (2000), como uma expressão subconsciente da ideologia imperialista ${ }^{9}$.

7 "Moving the source of terror from the supernatural to the scientific, Shelley's gothic novel exemplified the Romantic rejection of the eighteenth-century Cartesian belief in the scientist as hero and technology as inherently good. Frankstein expressed the fears of an entire mal-du-sciècle generation caught in a sudden paradigm shift between tradition and modernity. As such, the novel proved to be highly influential and popularized what was to become a standard nineteenth-century SF archetype: the mad scientist who, in hubrisfilled pursuit of knowledge and power, betrays basic human values".

8 "The explosion of sf-type during the nineteenth century can be understood only within the historical context of the industrial revolution and the transformative (and often alienating) social changes that accompained it".

9 “[...] Não é coincidência que a ficção científica britânica tenha experimentado uma onda de criatividade na época de Wells, Bram Stoker (1847-1912), Olaf Stapledon (1886-1950) e Rider Haggard (1865- 925); porque nesse período vimos o apogeu da aventura imperialista britânica. Similarmente, o lançamento dos EUA a um projeto de dominação mundial após a Segunda Guerra emoldura um florescimento equivalente na ficção científica americana, a então chamada 'Golden Age', que atravessa os anos 1950 e 1960, manifesta não só em textos que articulam uma ansiedade imperial (por exemplo, The Invasion of the Body Snatchers, 1956), mas também em obras (como a série Star Trek) sobre a exploração de novas fronteiras, transferindo a colonização do continente americano diretamente para a galáxia" (ROBERTS, 2000, p. 66). 
Sobre a ciência presente no gênero, Allen (1974) ressalta que as ciências humanas e suas tecnologias também devem ser consideradas, e cria a subdivisão que ele classifica como "ficção científica hard", baseada nas ciências físicas ou exatas, e "ficção científica soft", originária das ciências humanas, sendo que em ambas é pressuposta a existência de um universo ordenado com leis constantes e passíveis de serem descobertas (ALLEN, 1974, p. 21).

Atualmente, a ficção científica está ramificada em diversos subgêneros, como Space Opera, Historia Alternativa, Apocalíptico, Futurista, Afrofuturismo, Distopias/ Utopias, entre outros, e se faz presente como entretenimento em todos os suportes midiáticos. Como subgênero, as utopias e as distopias, estão, de certo, entre os mais populares. O termo utopia do grego, ou = não + topos = "lugar", formando a expressão "o não lugar" (CUDDON, 1999, p. 957) - foi cunhado por Thomas Morus com a publicação de seu livro homônimo em 1516. As utopias foram caracterizadas por Sargent (1994, p. 9) como uma sociedade imaginária, detalhadamente descrita e localizada no tempo-espaço, sendo o termo muitas vezes utilizado por autores/as para designar eutopias - projeções de futuro ou realidades alternativas positivas. De acordo com James (2003, p. 220, tradução nossa ${ }^{10}$ ): “A maioria das utopias [eutopias] eliminou o dinheiro e a propriedade privada, acabando, portanto, com a ganância, o roubo a inveja e a maior parte dos conflitos civis. A razão e a boa vontade seriam o suficiente para garantir a paz e a harmonia na comunidade [...]”. Segundo o mesmo autor (Ibid.), no século $\mathrm{XX}$, tais visões utópicas/eutópicas foram atacadas por aqueles que as interpretavam como “[...] sociedades opressivas, seja pela tirania do sistema 'perfeito' sobre a vontade individual, ou pela dificuldade de parar indivíduos ou elites de impor sua autoridade sobre a maioria, ou, na verdade, minorias." (Ibid., p. 220, tradução nossa ${ }^{11}$ ). Por outro lado, as distopias projeções de futuro ou realidades alternativas negativas - buscam apresentar aos/às leitores/as sociedades em condições mais críticas quando comparadas à atualidade (SARGENT, op. cit., p. 9). Há também a sátira utópica - crítica à sociedade contemporânea à do/a autor/a - e a antiutopia, que critica o ideal utópico no geral ou uma utopia específica.

De acordo com Cuddon (1999, p. 959), a partir do século XIX, em decorrência das revoluções francesa e industrial, as utopias passaram a desempenhar um importante papel no

10 "Most utopias eliminated money and private property, thus at one stroke removing greed, theft, jealousy and most causes of civil strife. Reason and good will would be sufficient to provide peace and harmony within the community [...]”.

11 “" [... opressive societies, either because the tyranny of the 'perfect' system over the will of individual, or because of the difficulty of stopping individuals or elites from imposing authority over the majority, or, indeed, over minorities". 
campo cultural, pois questionaram aspectos das diversas mudanças sociais ocorridas na época, estando presentes, inclusive, no campo filosófico.

Para uma melhor compreensão das influências e possíveis acepções da ficção científica e do subgênero da utopia em nossa sociedade, temos aqui um breve apanhado dos estudos de Fredric Jameson, os quais tivemos como base para o desenvolvimento desta pesquisa.

\subsection{Pós-Modernidade e Utopia em Fredric Jameson}

Antes de nos debruçarmos sobre a visão de Fredric Jameson acerca das narrativas utópicas, é preciso compreender um outro conceito chave no pensamento deste autor: a pósmodernidade.

Baseado nas teorias de Ernest Mandel (1992), Jameson (1996) atrela a superação do movimento moderno à conquista do estágio mais puro e completo do sistema capitalista, o capitalismo tardio. Essa etapa, iniciada no final da década de 1950 como consequência da canonização e institucionalização acadêmica do movimento moderno, é caracterizada, segundo Costa e Cevasco (1996, p. 5), pela expansão da mercadoria a nível global (a globalização), de forma que é impossível denominar algum lugar como "fora do sistema", nem mesmo a natureza, desde o desaparecimento da agricultura pré-capitalista, ou o inconsciente, que recebe a todo momento estímulos midiáticos e de propaganda.

Para Jameson, a pós-modernidade é a lógica cultural que age no capitalismo tardio e, dessa forma, não deve ser entendida como apenas um estilo, mas como algo maior, uma dominante cultural que permite a coexistência de características as quais, apesar de bastante distintas, estão subordinadas umas às outras. Ele explica:

\footnotetext{
O que ocorre é que a produção estética hoje está integrada à produção das mercadorias em geral: a urgência desvairada da economia em produzir novas séries de produtos que cada vez mais pareçam novidades (de roupas a aviões), com um ritmo de turn over cada vez maior, atribui uma posição e função estrutural cada vez mais essenciais à inovação estética e ao experimentalismo. (JAMESON, 1996, p. 30).
}

A própria produção cultural torna-se um produto, e o consumo dessas mercadorias o processo. Contudo, Jameson (Ibid., p. 31) esclarece que nem toda produção cultural do capitalismo tardio é pós-moderna, mas é preciso aplicar essa como dominante cultural para que o presente não seja entendido como heterogêneo e com diferenças aleatórias. Assim, em 
nosso entendimento, tal lógica de produção aplica-se à cultura da mídia no sentido desenvolvido por Kellner.

Como consequência dessa dinâmica, os produtos culturais do capitalismo tardio adquirem características como falta de profundidade e de historicidade, o que auxilia o aprisionamento dos indivíduos num presente perpétuo e os impede de enxergar a totalidade do sistema ou de se perceber enquanto sujeito histórico. No contexto descrito, a preocupação de Jameson é, nas palavras de Marcelino (2017, p. 170): “como dar conta dessa prisão pósmoderna, que teria sido intensificada pelo descrédito aos discursos políticos com aspirações universais a partir dos anos 1990". A proposta é, então, a criação de um modelo de análise para identificar formas de resistência e enfrentamento dessa situação por meio de uma política marxista, o que ele chama de mapeamento cognitivo, definido como: "uma cultura política e pedagógica que busque dotar o sujeito individual de um sentido mais aguçado de seu lugar no sistema global” (JAMESON, 1996, p. 79). É aí que a ficção científica aparece de forma estratégica, pois, segundo Jameson (2005), esse gênero possui uma maneira específica de operar, em que no estabelecimento do desconhecido, desfamiliariza e reestrutura nossas experiências do presente, num processo de distração e deslocamento denominado neutralização, o qual Peter Fitting (1998) nos esclarece que pode ser compreendido de forma análoga à crítica ou à negação:

[...] se nos referirmos às definições familiares de utopias literárias como contendo tanto a crítica à sociedade do autor quanto um modelo de uma [sociedade] melhor (SUVIN, 1979, p. 54), 'neutralização' no sentido utilizado por Jameson pode ser vista como análoga à ideia de crítica ou negação. (FITTING, 1998, p. 10, tradução nossa ${ }^{12}$ ).

Dessa forma, compreendemos que quando somos expostos a imagens do futuro, de realidades alternativas ou até mesmo de outras formas de vida, nos encontramos olhando para questões de nossas condições atuais.

Para a análise de narrativas de ficção científica, Jameson aposta na utilização da semiótica de linha francesa. Para o autor, as relações de oposição e negação entre os termos no quadrado semiótico - como veremos adiante no capítulo sobre a metodologia utilizada nesta pesquisa -, além de demonstrar relações mais profundas entre os grupos temáticos,

12 " [...] if we refer to the familiar definitions of the literary utopia as containing both the critique of the author's existing society as well as a model of a better one (e.g. Suvin: 54), 'neutralization' in Jameson's dynamic terms, may be seen as an analogue to the idea of a critique or negation" (FITTING, 1998, p. 10). 
também tornam o ato interpretativo mais ambicioso, se especulativo (JAMESON, 2005, p. 373).

Como subgênero da FC, as utopias em especial ajudam a revelar sintomas da pósmodernidade e da globalização, pois nos ajudam a transcender a incapacidade característica de nosso tempo de imaginar formas de futuro que não sejam prolongações do presente em que nos encontramos presos, assim, podem também ser compreendidas como sintomas sociais. Contudo, este teórico não as vincula à natureza humana, mas as vê como produtos da modernidade ocidental cujos temas não são aleatórios ou simples frutos de obsessões pessoais, são o registro da realidade social. Sua construção se deve a um materialismo histórico em conjunto com a vocação utópica, entendida como uma busca persistente e obsessiva por respostas simples, imediatas e autoexplicativas a dilemas específicos (JAMESON, 2005). Sobre essa busca, ele afirma que:

[...] é a situação social que deve admitir tal solução ou pelo menos sua possibilidade: esse é um aspecto da pré-condição objetiva da utopia. A abordagem histórica de uma situação social em particular deve encorajar tais simplificações; as misérias e injustiças visíveis devem se moldar ou se organizar em torno de um mal específico. Para o remédio utópico deve haver a princípio uma negativa fundamental para a qual esse se posta como um claro chamado para remover e extirpar essa específica raiz de todo o mal (Ibid., p. 12, tradução $\left.\operatorname{nossa}^{13}\right)$.

Por isso, ele nos alerta que abordar as utopias com expectativas positivas, mesmo que essas nos ofereçam visões de mundos melhores, é um erro e caracteriza uma política liberal, pois o estabelecimento de critérios positivos da sociedade almejada focaria a manutenção do conforto burguês, ao invés de diagnosticar a fonte do desejo utópico, geralmente originada na exploração e sofrimento presentes (Ibid., p. 12). Do contrário, um programa propriamente utópico deve alcançar um nível de complexidade que o permita mostrar o problema em primeiro plano e necessita, em nome da autonomia e autossuficiência, se comprometer com sua totalidade (combinação entre o fechamento e o sistema), "[...] que em última instância é a fonte dessa alteridade ou diferença radical, mesmo que alienígena” (Ibid., p. 5, tradução

13 “[ ...] it's the social situation which must admit of such a solution, or at least it's possibility: this is one aspect of the objective preconditions for a Utopia. The view that opens out onto history from a particular social situation must encorage such oversimplifications; the miseries and injustices thus visible must seem to shape and organize themselves around one specific ill or wrong. For the Utopian remedy must at first be a fundamentally negative one, and stand as a clarion call to remove and to extirpate this specific root of all evil from each all the others spring". 
nossa $\left.{ }^{14}\right)$.

Inspirado pelos estudos de Ernst Bloch (1995) sobre um impulso utópico orientar nossas vidas nos âmbitos pessoal e cultural ${ }^{15}$ - o que sempre nos faz desejar uma vida melhor -, Jameson (2005, p. 5) afirma também ser possível encontrar alegorias de utopias no cotidiano, muitas vezes de forma inconsciente, oferecendo um prazer que vai além de seu valor funcional ou satisfação oficial. O autor entende que quando as pessoas projetam no futuro suas incertezas e angústias acerca do presente, a utopia se torna uma compensação subjetiva, uma forma de resolver no imaginário conflitos que não podem ser superados no real.

Jameson conclui que as utopias não nos ajudam a imaginar o futuro, mas demonstram nossa incapacidade de concebê-lo; segundo ele, elas são: “nossa prisão num presente não utópico e sem historicidade nem futuridade - para revelar o fechamento ideológico do sistema em que estamos, de algum modo, cercados e confinados" (JAMESON, 2004, p. 169). Assim, a criação de uma utopia literária - em nosso caso, cinematográfica - diferente do que é compreendido por Eco e Allen, não é apenas uma especulação sobre o futuro, mas sim uma forma de práxis, pois se torna uma forma de refletir e agir sobre o presente.

\subsection{A Ficção Científica no Brasil}

Devido à associação da ficção científica ao imaginário da evolução das ciências e da tecnologia, imaginá-la no contexto de um país que historicamente não possui longa tradição na produção de C\&T e teve seu desenvolvimento industrial tardio, como o Brasil, pode soar estranho tanto na literatura quanto no cinema, dessa forma, não raro, a FC é encarada como um gênero estrangeiro. Como outras possíveis causas para tal descrédito, a estudiosa da ficção científica latino-americana, Mary Elizabeth Ginway (2005a, p. 29), também aponta associações com a arte "baixa" e a ficção popular, além do alto valor dado pelo país ao realismo literário.

Apesar do quadro de desfavorecimento, desde o final do século XIX, sementes da FC têm sido esporadicamente plantadas em nosso solo, é o que nos prova O Doutor Benignus, de Augusto Emílio Zaluar, publicado em 1875 e considerado o primeiro romance de fícção

14 "Totality is then precisely this combinaton of closure and system, in the name of autonomy and selfsufciency and which is ultimately the source of that otherness or radical, even alien, difference".

15 Em sua obra O Princípio da Esperança, originalmente publicada em língua alemã em três volumes entre 1954 e 1959, Bloch estuda como expressões da cultura popular, da grande literatura, filosofia, religião e utopias políticas e sociais apresentam momentos emancipatórios que revelam desejos por uma vida melhor e levantam dúvidas sobre a vida no capitalismo ou no socialismo estatal. 
científica brasileira $^{16}$, segundo pesquisa de Andrade (2014, p. 48). Em matéria feita para a Revista FAPESP, Fioravanti (2016, p. 91) conta que após o livro de Zaluar até a primeira metade do século XX, a FC apareceu de forma eventual em nossa literatura, até, segundo Roberto de Sousa Causo (2003, p. 163), passar a ser mais recorrente na década de 1930 com Berilo Neves e Jerônymo Monteiro.

De acordo com Causo (2003), entre 1958 e 1971, aproximadamente, temos a Primeira Onda da ficção científica no Brasil, na qual destaca-se o núcleo do editor Gumercindo Rocha Dórea (GRD), que além de publicar autores internacionais consagrados, como Heinlein, Bradbury, entre outros, dedicou-se à divulgação de autores/as brasileiros/as, tanto experientes como iniciantes no gênero, revelando nomes como André Carneiro, Dinah de Souza Queiroz e Bráulio Tavares. Já nos anos 80, foram os fanzines - publicações feitas por fãs - que marcaram a Segunda Onda, entre 1982 e 1997, após um período de dispersão ocorrido entre os anos de 1971 e 1981. Desde o fim da Segunda Onda, para Causo (Ibid.), a FC vive sua renovação, com autores como Gerson Lodi-Ribeiro, Max Mallmann e Octavio Aragão.

É interessante repararmos na simultaneidade entre a emergência da Primeira Onda e o desenvolvimento industrial brasileiro. Ao levarmos em conta a alegação de Darko Suvin $(1979$, p. 84) que diz que em toda ficção científica a fuga é uma forma de se obter um melhor ponto de vista para a compreensão das relações humanas ao redor do autor, juntamente ao conceito de neutralização utilizado por Jameson (2005) discorrido anteriormente, consideramos que tal sincronia deve ser vista como um sintoma das políticas de modernização da época e não como simples coincidência, o que reforça a associação do gênero com o desenvolvimento industrial, científico e tecnológico.

Sob perspectiva semelhante, M. Elizabeth Ginway (2005a, p. 13) identifica na ficção científica o veículo ideal para o exame da percepção e do impacto cultural do processo de modernização no Brasil. Baseada em mitos da nacionalidade brasileira e em paradigmas da FC anglo-americana, em seu livro Ficção Científica Brasileira: mitos culturais e nacionalidade no país do futuro, a autora analisa os discursos presentes na literatura brasileira de FC a partir da década de 1960, e observa que no início, a maior parte dos/as escritores/as criava histórias com viés antitecnológico e apocalíptico como forma de afirmação dos mitos que constituem a

16 Haywood Ferreira (2007) lembra que poucos anos antes, mesmo que com toques de espiritismo, fragmentos quase que semanais de Páginas da História do Brasil Escrita nos Anos 2000, de Joaquim Felício dos Santos, foram publicados no jornal O Jequitinhonha entre os anos de 1868 e 1872, e, posteriormente, foram considerados por Magalhães (1940 apud FERREIRA, 2007, p. 442, tradução nossa) como "a melhor crítica da monarquia em nosso país". 
identidade brasileira (GINWAY, 2005a, p. 14). Já nos anos 1970, mundos distópicos foram criados como forma de protesto à ditadura militar e os mitos da cultura brasileira foram utilizados de forma a criticar males associados à urbanização, à industrialização e à repressão (Ibid., p. 14).

A partir da década de 1980, para Ginway (Ibid.), a pós-modernidade e a globalização tornaram os problemas sociais mais complexos e, após duas décadas de modernização, começou-se a abordar as consequências da tecnologia e do desenvolvimento na sociedade contemporânea sob o viés de questões como gênero sexual, raça e classe social (GINWAY, 2005a, p. 16). Como um dos exemplos deste último quadro, Ginway (2005b, p. 477) cita “África”, de Fábio Fernandes (2003) - história em que um vírus desconhecido ataca apenas a população branca, e o tratamento encontrado passa a ser a pigmentação artificial da pele para tratar questões como colonialismo, escravização e conflito racial, que têm ressonância no Brasil e nos EUA. Nessa narrativa, segundo ela: "Claramente, a ideia de brancos terem de escurecer a pele é algo que radicalmente remonta à identidade física e social, enquanto também nos convida a repensar a dominância econômica e cultural dos EUA e da Europa sobre a África e outras partes do mundo" (Ibid., p. 477, tradução nossa ${ }^{17}$ ).

Se em 2005, a mesma autora alegou prevalecer a (falsa) ideia de que um país do terceiro mundo não poderia produzir ficção científica de forma autêntica (GINWAY, 2005a, p. 27), em 2019, quadro semelhante se mantém no cinema, sendo poucas as investidas quando comparadas a outros gêneros ${ }^{18}$. Segundo Alfredo Suppia $(2007$, p. 2), este quadro se dá devido a uma junção de fatores, como o custo elevado da produção cinematográfica e sua demanda por infraestrutura, além de ser um terreno no qual a disputa com obras estrangeiras se torna mais acirrada.

Em sua análise sobre o cinema de FC mexicano, Estevão Garcia (2007) identifica um cenário que podemos assimilar ao brasileiro. Para ele, os elementos característicos da ficção científica e do terror não se apresentam no cotidiano com a mesma facilidade de ícones da comédia e do melodrama, além disso: “[...] as suas visualidades características não são

17 "Clearly the idea of whites having to darken their skin is an idea that radically reshapes physical and social identity, while also inviting us to reconsider the United States' and Europe's economic and cultural dominance over Africa and other parts of the world".

18 Chegamos a essa conclusão a partir do estudo de dados levantados pelo Observatório Brasileiro do Cinema e do Audiovisual (2018a), atualizado anualmente, a respeito da arrecadação em bilheteria entre os anos de 2009 e 2017, com discriminação de distribuidoras, ano, semanas em exibição e gênero cinematográfico. No documento em questão a ficção científica não consta como gênero, o que já nos diz muito sobre sua presença no cinema brasileiro; devido a isso consideramos sua presença mesmo que não como gênero dominante. 
reconhecidas no cotidiano ou na experiência de se viver em um país chamado México, ou em país algum, e sim através do consumo de objetos culturais estrangeiros" (GARCIA, 2007, p. 1). Além disso, a predominância tanto na produção quanto na representação estadunidense em filmes de $s c i$ - $f i$ contribuiu para gerar uma assimilação direta:

No cinema, sempre que os alienígenas penetravam na atmosfera terrestre, o local de pouso obrigatório tinha que ser os EUA. Os astronautas que exploravam o espaço também sempre eram de nacionalidade americana, e quando os ETs travavam um primeiro contato com um terráqueo, o idioma emanado de suas bocas era sempre o inglês. Os EUA eram o sinônimo de planeta Terra. (Ibid, p. 2).

Contudo, assim como Suppia (2007, p. 3), defendemos que podemos sim falar em ficção científica no cinema do Brasil, ainda que não num cenário ideal e com algumas especificidades que muitas vezes a impedem de ser reconhecida como tal ou como a dominante genérica da narrativa. Uma dessas particularidades seria o fator fake. Como descrito por Bernadete Lyra (2004) em análise sobre a estética das chanchadas, o conceito de fake - falso, em inglês - é geralmente aplicado a paródias, mas não se limita a elas, e indica um "[...] espaço de repetição onde algo simula ser outro algo" (LYRA, 2004, p. 185), e ressalta que não remete ao aleatório ou ao mau gosto:

o fake [...] dá a dimensão de que existe um "outro", ou seja, um verdadeiro no horizonte, $[\ldots]$ é determinado e determinante em sua missão de dar forma aos imaginários espectatoriais, pois que são, repetidamente, acionados e repercutem nos filmes do gênero. [...] o que é fake foi criado para ser verossímil, dentro das expectativas de uma identidade imaginária que une os elementos em jogo no campo cinematográfico.

Por outro lado, como fator atuante, o fake trabalha pelo esbatimento das fronteiras entre as formas organizadoras [...], conferindo a esse tipo de filmes uma inteligibilidade histórica que põe em funcionamento mecanismos de intercâmbio e cruzamento entre diversas estruturas narrativas e modos de ser e de ver (Ibid., p. 184).

Ao transpormos para a FC o contexto identificado por Lyra nas chanchadas, identificamos que o fake também se faz presente na imitação de um padrão estético de outras cinematografias (principalmente em filmes que parodiam grandes produções estrangeiras) e que o próprio filme nega e tenta subverter ao utilizar as iconografias do gênero de maneira acessória e/ou fora do contexto esperado, remetendo, assim como interpretou Suppia (2007, p. 328), à precariedade e ao kitsch no cinema brasileiro. Porém, a FC brasileira, ao deslocar as iconografias do contexto esperado, não se apropria das mesmas de forma antropofágica, 
dificultando a suspensão da realidade necessária. Sobre isso, Garcia diz:

A potencialidade da expressão dessas características não se origina apenas da relação de dependência cultural, política e econômica travada entre esses países [do $3^{\circ}$ Mundo] e os EUA, mas também da 'nossa incapacidade de copiar'. Mesmo querendo copiar, nós transformamos a nosso modo o modelo original. Nascidos e formados por uma invasão, 'nada nos é estrangeiro, pois tudo o é'. [...] Tal operação é realizada de maneira espontânea porque o diálogo que encontramos nesses filmes entre cultura local e cultura dominante ultrapassa a intenção antropofágica. Não visualizamos neles um projeto consciente de absorver e deglutir o que vem de fora para a criação de algo totalmente novo e nacional (GARCIA, 2007, p. 2).

Porém, quando essa subversão não se faz presente nas obras de verba mais modesta, temos os chamados "filmes B". É interessante refletirmos sobre o porquê de obras de baixo orçamento de cinematografias não hegemônicas serem automaticamente classificadas como paródias enquanto produções semelhantes vindas dos EUA são tomadas apenas como filmes precários. Para Garcia (2007, p. 3), isso não ocorre devido à precariedade de recursos, mas pela constante presença de elementos que provocam comicidade, voluntária ou involuntariamente, causada pelo processo de reinvenção quando as iconografias são utilizadas em contexto estrangeiro.

A partir do levantamento panorâmico da história da FC no cinema brasileiro feito em Atmosfera Rarefeita, Suppia (2007) identifica duas principais correntes de manifestação: uma que inclui comédias que trabalham por meio de paródias, e outra cujos filmes abordam problemáticas ecológicas/ambientais, para longas-metragens. Já para curtas-metragens, a principal corrente de manifestação é a das viagens no tempo. Segundo o pesquisador, as paródias são hegemônicas e apesar de muitas vezes a FC não ser a dominante genérica, o formato se apropria dos mais diversos temas ligados a ela; seus ícones característicos, não raro, apresentam funções cômicas, alegóricas ou satíricas. Suppia (2007) observa que nessa corrente, além de sempre estar presente o fator fake, também se sobressai, em suas palavras: “[...] uma apropriação irreverente de modelos, ícones ou imagens da fícção científica hegemônica, redimensionados ou retrabalhados num discurso tipicamente brasileiro" (SUPPIA, 2007, p. 318), e que o pastiche ou a imitação tendem a aparecer com mais frequência do que a sátira (Ibid., p. 319). Para essa discussão, Suppia se apoia em João Luiz Vieira (2007), que esclarece: "Diferente da sátira, a paródia não é necessariamente crítica. Não obstante, no cinema brasileiro a linha entre paródia e sátira é com frequência muito 
tênue. Num sentido amplo, a paródia algumas vezes se torna uma sátira de si mesma, criticando o cinema brasileiro" (VIEIRA ${ }^{19}$, 1995, p. 257 apud SUPPIA, 2007, p. 319).

É possível enxergarmos os traços da vertente paródica, por exemplo, em alguns filmes da série Os Trapalhões que contém traços de ficção científica, como Os Trapalhões no Planalto dos Macacos (TANKO, 1976) e O Trapalhão na Guerra dos Planetas (STUART, 1978). Por outro lado, a a corrente que trata de temáticas ambientais é caracterizada por Suppia (2007, p. 333) como “[...] mais 'pura', mais rara e de intenções mais sérias [...] (ou melhor, que se leva a sério)”. A diferença é que desde o início, esses filmes se propõem a ser ficção científica, tanto em seus temas quanto nas formas de abordagem, e são mais fechados no contexto brasileiro, como é o caso, por exemplo, de Abrigo Nuclear, de Roberto Pires (1981). Porém, segundo o pesquisador, essa vertente também está sujeita ao fator fake por se inspirar em obras estrangeiras, principalmente estadunidenses, feitas em outro contexto de produção.

Contudo, hoje em dia, já não enxergamos na maioria das produções brasileiras contemporâneas uma precariedade técnica limitante. Ainda que com todos os percalços de produção, elas têm apresentado histórias cada vez mais afinadas e efeitos especiais mais profissionais; e, mesmo quando a técnica ou o orçamento são fatores limitantes, as soluções encontradas têm sido criativas e com traços da cor local, de forma que o fake não se sobressai à narrativa, como é o caso de Branco Sai, Preto Fica, de Adirley Queirós (2014), analisado neste trabalho.

\subsection{O Cinema Brasileiro de Ficção Científica}

De acordo com Suppia (2007), existe certa dificuldade em precisar um marco para o início da ficção científica no cinema brasileiro por não haver em nossa história uma personalidade análoga a George Méliès, tendo sido poucas as investidas de realizadores/as nacionais, durante a fase do Primeiro Cinema, nos gêneros fantástico e maravilhoso (SUPPIA, 2007, p. 87). Contudo, isso não quer dizer que não possamos identificar uma evolução, ainda que tímida, da FC como um gênero autêntico em nossa cinematografia. Podemos falar com mais segurança a respeito de obras brasileiras com um toque de FC a partir de 1947, quando foi lançado o filme Uma Aventura aos 40, de Silveira Sampaio. 
Nos anos 1950, a FC foi incorporada pelas chanchadas dos estúdios Atlântida e Vera Cruz e por algumas comédias. Simão, o Caolho (CAVALCANTI, 1952), Nadando em Dinheiro (ALMEIDA, 1953), Carnaval em Marte (MACEDO, 1954), Malandros em Quarta Dimensão (BARROS, 1954) e O Homem do Sputnik (MANGA, 1959), trouxeram iconografias clássicas que remetem ao gênero de maneira acessória à narrativa (o cientista, o robô e o extraterrestre), tendência que se repetiu nas décadas posteriores, com raras exceções do contrário.

Também é interessante recordarmos que a FC se fez presente nos movimentos do Cinema Novo e do Cinema Marginal - Brasil Ano 2000 (LIMA JR, 1969) e O Bandido da Luz Vermelha (SGANZERLA, 1968) são respectivos exemplos. Mesmo que com raras aparições, cumpriram uma das mais importantes funções da fantasia, a de driblar a censura da ditadura por meio de suas alegorias para tratar de assuntos polêmicos - o processo de neutralização descrito por Jameson.

Nos anos 2000, período de recorte desta pesquisa, as ecocatástrofes, foram bastante presentes no histórico da FC brasileira como um todo, e marcaram presença de forma longa em Acquária (MORAES, 2004) e em formato curto em Recife Frio (FILHO, 2009). Escrito por Cláudio Galperin e dirigido por Flávia Morais, Acquária (2004) apresentou uma distopia sobre um futuro com esgotamento dos recursos naturais voltada para o público infantojuvenil, com a dupla de cantores Sandy \& Júnior nos papeis principais. Já Recife Frio (2009), do diretor Kléber Mendonça Filho, usou uma súbita e inexplicável mudança de clima em Recife para falar a respeito do tema da especulação imobiliária. Em 2005, a representação ficou por conta de A Máquina, dirigido por João Falcão, e Um Lobisomem na Amazônia, de Ivan Cardoso, ambos não encaixados perfeitamente como ficções científicas, pois os novum não eram os elementos centrais da história, mas com a presença de iconografias relevantes.

Anos mais tarde, a ficção científica com toques de comédia e de romance, O Homem do Futuro (2011), dirigido por Cláudio Torres e com a presença de um dos atores mais cotados do cinema nacional da época, Wagner Moura, levou mais de 1 milhão de pessoas às salas de cinema. Nele, Zero é um brilhante físico amargurado pela perda de seu grande amor no passado. Em 2013, Eder Santos lançou Deserto Azul, utopia com atmosfera onírica que, apesar de contar com um elenco de renome e ter circulado por festivais nacionais e internacionais, não foi lançado em circuito comercial.

Como produção de longa-metragem recente, não podemos deixar de citar Branco Sai, 
Preto Fica (2014) e Era uma Vez Brasília (2017), ambos do cineasta Adirley Queirós. Híbridos entre documentário e ficção científica $\mathrm{B}$, os filmes são manifestos contra a violência sofrida pela negritude no Brasil.

A popularização dos equipamentos digitais foi um fator de peso para possibilitar novas experimentações no cinema de curta e média-metragem, tanto em nível técnico quanto para facilitar produções de novas/os realizadoras/es. Céus de Fuligem (2005), de Marco Nápoli, é um bom exemplo da primeira situação. Observa-se na obra a ênfase dada ao design computadorizado dos cenários e na tentativa de efeitos especiais em detrimento ao desenrolar da história. Por tentar imitar blockbusters internacionais, o filme recai no fator fake. $\mathrm{Na}$ contramão, Nada Consta (2007), de Santiago Dellape, produzido no curso de cinema da Universidade de Brasília, é uma comédia de baixo orçamento sobre a burocracia estatal que não chega a ser um filme B por se utilizar de artifícios no roteiro, concepção estética noir e trucagens para a criação dos efeitos especiais.

Em seu levantamento que abrange até o ano de 2007, Alfredo Suppia (2007) realça o trabalho do curta-metragista Carlos Canela, com pelo menos três interessantes trabalhos de FC: Bailarina (2001), Dois Lados (2003) e O Homem da Cabeça de Papelão (2007).

Alguns curtas-metragens se aproveitaram da FC para metaforizar a incomunicabilidade pela ausência de diálogos e a presença de alegorias, como é o caso de Quarto de Espera (2009), dirigido por Bruno Carboni e Davi Pretto, e Zigurate (2009), de Carlos Eduardo Nogueira. Já no filme Confinópolis - A terra dos sem chave (2011), de Raphael Araújo, a cobertura no rosto das pessoas em situações cotidianas juntamente à narração crítica ao status quo pode ser lida como uma metáfora sobre a alienação.

O cinema curto brasileiro também não deixou de abordar iconografias clássicas da FC no século XXI, o tempo, os alienígenas e cientista maluco que tenta criar uma nova forma de vida estão presentes, respectivamente, em Tempo Real (LIMAVERDE; BARROS, 2005), Deep Space Worms - Os horrendos vermes do espaço profundo (VALENTINI, 2008) e O Homem Planta (SEVERIEN, 2011).

A ficção científica também esteve presente no maior veículo de comunicação do país, a televisão. Reconhecidas internacionalmente, algumas telenovelas brasileiras incorporaram o gênero, como o caso da produção da Rede Globo, O Clone (2001), que dramatizou a clonagem humana. Exportada para diversos países, O Clone bateu recordes de audiência na 
época de sua primeira exibição ${ }^{20}$. Recentemente, em 2017, a mesma emissora produziu e transmitiu em seu horário nobre a minissérie A Fórmula, na qual uma cientista, para conquistar o homem que ama, inventa uma fórmula da juventude; e em 2018, a novela Tempos Modernos, que abordou o tema da criogenia.

O formato seriado, cada vez mais popular em todo mundo, tem apresentado diversas obras de FC. A Netflix, plataforma mais popular de streaming do mundo, com mais de 100 milhões de assinantes, apostou numa distopia como tema de sua primeira produção de ficção seriada original totalmente brasileira. 3\% (AGUILERA, 2016) se passa num Brasil pósapocalíptico em que grande parte da população vive em situação de miséria, porém, ao atingir os 20 anos de idade, $3 \%$ dos cidadãos e cidadãs tem direito de tentar uma vida melhor em Maralto, lugar de conforto e fartura. No entanto, para isso, é preciso passar pelo Processo, uma rígida seleção que envolve provas físicas e morais; uma vez que a/o participante é eliminada/o, fica impedida/o de tentar novamente no ano seguinte. A primeira temporada, composta por oito episódios com cerca de 40 minutos cada, foi sucesso imediato e logo se tornou a ficção seriada de língua não-inglesa mais vista nos Estados Unidos. Uma segunda temporada foi lançada em 2018 e há expectativa de uma terceira para 2020.

No catálogo brasileiro da mesma plataforma também constam 4 episódios de Horizonte B (2016), narrativa ambientada no Rio Grande do Sul, criada por Tomás Fleck, Gabriel Faccini e Tiago Rezende, que conta a história dos irmãos Matheus e João e sua busca pela origem de uma misteriosa pedra que caiu do céu. Em viagem até a cidade de Santa Maria, eles descobrem que não são os únicos interessados no objeto e suas vidas passam a correr perigo. Como apenas parte da história foi disponibilizada, ainda não é possível caracterizá-la com certeza como uma autêntica FC.

20 Dados retirados do site da emissora. Disponível em: $<\mathrm{http}: / /$ memoriaglobo.globo.com/programas/entretenimento/novelas/o-clone/o-clone-inicio.htm $>$. Acesso em 11 jan. 2018. 


\section{METODOLOGIA}

Devido à complexidade cultural que toda obra cinematográfica carrega em sua essência, analisar um filme em seu discurso se torna um processo com diversas variáveis. Com isso em vista, optamos por uma metodologia que articula a Semiótica francesa (semiótica de Greimas) e os Estudos Culturais.

Ao considerarmos que todos os constituintes de um filme formam seu texto, desde o roteiro ao tratamento das cores, e que a semiótica, segundo Barros (2005, p. 11): “[...] procura descrever e explicar o que o texto diz e como ele faz para dizer o que diz", acreditamos na eficácia do método de Greimas para atingirmos nossa finalidade, pois esse analisa as relações sintagmáticas internas ao texto, a fim de evidenciar não só as estruturas narrativas presentes, mas também oposições de valores implícitos e explícitos, o que nos auxilia a enxergar com mais clareza os sujeitos, as motivações por trás das ações e suas consequências dentro de um contexto estabelecido pela narrativa. No cinema, a aplicação desta heurística não se restringe ao literal e abrange também o visual, como a paleta de cores, os enquadramentos escolhidos, a montagem, e até mesmo a direção de atores.

No entanto, acreditamos que apenas uma análise estrutural é incompleta por não levar em conta as condições de produção desse discurso, nem os possíveis impactos sociais da obra em determinado tempo histórico, dessa forma, a união com os Estudos Culturais nos auxilia na construção de uma visão mais ampla, além de fornecer fundamentação histórica e crítica. Neste campo, escolhemos nos guiar pelos trabalhos de Douglas Kellner e Fredric Jameson, pois ambos, apesar de suas diferenças, creem que cultura e sociedade são terrenos de disputa influenciados por efeitos de produções culturais em determinados contextos.

Em suas obras, Kellner $(2003$; 2005) realiza uma leitura de espetáculos midiáticos voltados para as massas, para decifrar o que nos dizem sobre a vida contemporânea. A partir dos Estudos Culturais britânicos, que enfatizam a importância de uma articulação interseccional, principalmente entre gênero, raça e classe, e fazem leituras da cultura sob a ótica da produção e recepção de textos culturais inseridos em contextos históricos concretos junto a teorias sociais, as quais este autor entende como dispositivos que auxiliam na compreensão e interpretação da vida social (KELLNER, 2001). Kellner vai além da avaliação ideológica da cultura da mídia e também analisa a forma com que essa se apropria de conteúdos sociais e faz circular posições políticas e discursos ideológicos, o que permite a 
identificação de patologias contemporâneas, ansiedades, ambiguidades e contestações políticas (KELLNER, 2003, p. 28).

Já Fredric Jameson, apesar de também realizar sua crítica da cultura pelo viés dos Estudos Culturais e, por vezes, também com auxílio da semiótica, mostra preocupação em não apenas identificar os discursos emanados por objetos culturais e suas ideologias, mas também em revelar como esses estão inseridos em uma estrutura cultural e política maior, o capitalismo tardio, e de que forma contribuem para sua manutenção. Assim como Kellner (2001), Jameson (2005) destaca a importância dos simbolismos reproduzidos através da cultura de massas na difusão de ideologias, pensamentos políticos e modos de vida, pois compreende que é através do simbólico que conceitos abstratos, como as ideias de progresso e de modernidade, mascaram ideologias e assumem papéis próximos à função de personagens no inconsciente, tanto individual quanto coletivo. Para ele, os textos culturais são ao mesmo tempo ideológicos e utópicos, mesmo que não explicitamente, já que para sua manipulação necessitam oferecer ao público algum contentamento baseado nos mais fortes e fundamentais desejos do coletivo aos quais dão voz, mesmo que de forma distorcida (JAMESON, 1994).

Pela teoria do Inconsciente Político, formulada por Jameson (1992) para designar a percepção do trabalho artístico como alegorias de determinadas épocas (algo próximo a uma estrutura de sentimento), a prioridade epistemológica da fantasia na teoria e na prática são reafirmadas:

\begin{abstract}
A tarefa de tal teoria seria detectar e revelar - por trás dos rastros escritos do Inconsciente Político, como textos narrativos de alta ou baixa cultura de massas, além de outros sintomas ou traços, como opiniões, ideologias, e até mesmo sistemas filosóficos - os indícios de algum movimento narrativo mais profundo e vasto, no qual os grupos de uma dada coletividade em determinada conjuntura histórica, ansiosamente questionam sobre seu destino com esperança ou medo. (JAMESON, 2005, p. 282, tradução nossa ${ }^{21}$ ).
\end{abstract}

Exposto mesmo que brevemente o pensamento de Fredric Jameson, podemos concordar com Kellner quando esse, sob ótica semelhante, nos diz: “Os textos ideológicos, portanto, põem à mostra tanto os sonhos e os pesadelos significativos de uma cultura, quanto os modos como essa cultura está tentando canalizá-los para manter suas atuais relações de poder e

21 "The task of such a theory would then be to detect and to reveal - behind such written traces of the political unconscious as the narrative texts of high or mass culture, but also behind those other symptoms or traces which are opinion, ideology, and even philosophical systems - the outlines of some deeper and vaster narrative movement in which the groups of a given collectivity at a certain historical conjuncture anxiously interrogate their fate, and explore it with hope or dread". 
dominação" (KELLNER, 2001, p. 146). Dessa forma, compreendemos que toda e qualquer produção cultural, por ser concebida em um tempo histórico específico, por pessoas inseridas em determinados contextos socioculturais e com histórias de vida próprias, independente da vontade de seus/suas criadores/as, é carregada por ideologias.

Nosso trabalho aqui compreende a leitura de objetos culturais (filmes brasileiros de ficção científica), identificação do conjunto de mecanismos articulados que dão sentido à sua linguagem e a associação de seu discurso a determinadas ideologias características de seu tempo e que tenham alguma ligação aos princípios do Estado desenvolvimentista.

\subsection{Semiótica de Greimas}

Para a compreensão do mecanismo da semiótica de linha francesa, derivada dos trabalhos do lituano Algirdas Julien Greimas, é prudente, primeiro, a compreensão da linha de estudos da semiótica como um todo.

A partir do pensamento formulado pelo linguista Ferdinand Saussure (2001) com a Semiologia - estudo de diversos tipos de signos, não apenas textos verbais, em dinâmicas socais -, signos são compreendidos como unidades constituídas pela união de um significante, a "materialidade" (letras, fonemas, etc), com um significado (conceito). Ele explica:

\footnotetext{
O signo linguístico une não uma coisa e uma palavra, mas um conceito e uma imagem acústica. Esta não é o som material, coisa puramente física, mas a impressão (empreinte) psíquica desse som, a representação que dele nos dá o testemunho de nossos sentidos; tal imagem é sensorial e, se chegarmos a chamála "material", é somente nesse sentido e, por oposição ao outro termo da associação, o conceito, geralmente mais abstrato (SAUSSURE, 2001, p. 80).
}

Não há necessariamente uma relação entre a materialidade e o conceito, por exemplo, a imagem acústica de "caneta" não precisa de maneira obrigatória se referir a um objeto voltado ao ato da escrita, mas a usamos nesse sentido devido a uma convenção social.

Piassi (2012) explica que a relação entre significante e significado não é à parte dos demais entes de uma língua, o que implica no conceito de valor, também desenvolvido por Saussure (2001), que compreende um signo (relação significante - significado) em relação a outros signos com os quais há alguma proximidade: como, por exemplo, o signo "caderno" constitui uma relação de significação com os signos "livro", "caderneta" e "agenda" é possível situá-lo em um sistema. No entanto, o conceito também depende do contexto em que 
esse é inserido: a palavra "solo", por exemplo, de acordo com o contexto, pode expressar tanto algo feito por apenas uma pessoa, quanto pode ser empregada como sinônimo de "chão".

Dentro da área de estudos da linguística, a semiótica faz parte do conjunto de teorias que concebem o texto como unidade de sentido (a relação entre diversos signos distintos), e não a frase de maneira isolada (BARROS, 2005), dessa forma, o sentido da frase é atrelado ao sentido do texto. Um texto, em suas diferentes formas de representação, pode ser definido de duas formas distintas, porém, complementares: como objeto de significação, apresentando, de acordo com Barros (2005, p. 11): "[...] procedimentos e mecanismos que o estruturam e que o tecem como um todo de sentido", ou como objeto de comunicação entre dois sujeitos, ou seja, um objeto cultural, inserido em uma sociedade de classes e formado por ideologias específicas (Ibid., p. 11). Logo, para a análise do que o texto diz e de como ele diz, a semiótica leva em conta tanto os procedimentos de organização quanto os mecanismos de produção e de recepção dos enunciados.

$\mathrm{Na}$ semiótica francesa, o texto é visto como uma narrativa composta por três níveis: o fundamental (ou profundo), o narrativo e o discursivo, passando por patamares que vão do mais profundo ao mais externo, num processo denominado percurso gerativo de sentido, no qual os diferentes níveis se relacionam a partir de um conjunto de regras que rege o encadeamento das formas de conteúdo para formar um discurso dotado de significado (FIORIN, 2009).

O primeiro nível, o fundamental, é o mais abstrato. Nele encontramos as oposições semânticas básicas do texto, a partir das quais o sentido é construído. Aos elementos dessas oposições são atribuídos valores positivos (eufóricos) ou negativos (disfóricos), sempre determinados pelo contexto da narrativa, o que nos informa aspectos ideológicos do discurso. Já o nível seguinte, o narrativo, um pouco menos abstrato, é onde ocorre o programa narrativo de base, definido por Barros (2005) como a reação de um enunciado de fazer a um enunciado de estado, ou seja, ocorre uma transformação. Aqui, ainda segundo a autora, a narrativa é organizada do ponto de vista de um actante, definido como qualquer agente que realiza ou sofre uma ação, independente de ser representado por uma pessoa. Não se trata mais da negação ou afirmação de conteúdos, da aceitação ou recusa de algum valor, mas da transformação, pela ação do sujeito, de estados de liberdade ou de opressão (BARROS, 2005, p. 15). Nesta etapa, Fiorin (2009) alega que, por ser uma estrutura complexa, o texto passará 
pela sequência canônica de manipulação (ação de um actante sobre outro para induzi-lo a uma ação), competência (adquirimento pelo sujeito das ferramentas ou conhecimentos necessários para realizar a ação), performance (ocorrência da transformação central da narrativa, em que há uma mudança de estado), e sanção (recebimento, por parte do sujeito, do prêmio ou punição por sua performance).

Por fim, o nível discursivo é o mais direto ao/à leitor/a, porém, o mais complexo. Nele são examinadas as relações que se instauram entre o/a enunciador/a e o texto enunciado. São identificadas as personagens, os locais e os tempos da história, entre outros elementos materiais; o discurso revela-se sob uma forma de manifestação específica e perde-se a abstração tida a princípio.

A tabela abaixo demonstra a relação entre os níveis no percurso gerativo de sentido [Quadro 1]:

Quadro 1 - Etapas do Percurso Gerativo de Sentido

\begin{tabular}{|c|c|c|}
\hline Nível Discursivo & $\begin{array}{l}\text { Matearilização; relações figurativas } \\
\text { (identificação de espaços, } \\
\text { personagens e tempo) }\end{array}$ & $\begin{array}{l}\text { Etapa mais externa e menos } \\
\text { abstrata }\end{array}$ \\
\hline Nível Narrativo & $\begin{array}{l}\text { Organização da narrativa pelo } \\
\text { ponto de vista do actante } \\
\text { (formação do programa narrativo) }\end{array}$ & \\
\hline Nível Fundamental & $\begin{array}{l}\text { Oposições semânticas básicas; } \\
\text { atribuição de valores }\end{array}$ & $\begin{array}{l}\text { Etapa mais profunda e mais } \\
\text { abstrata }\end{array}$ \\
\hline
\end{tabular}

Fonte: Maria Estela Silva Andrade, 2019.

A articulação dos três níveis gera um quadrado semiótico [figura 1], por meio do qual é possível explicitar visualmente o percurso narrativo do sujeito: 


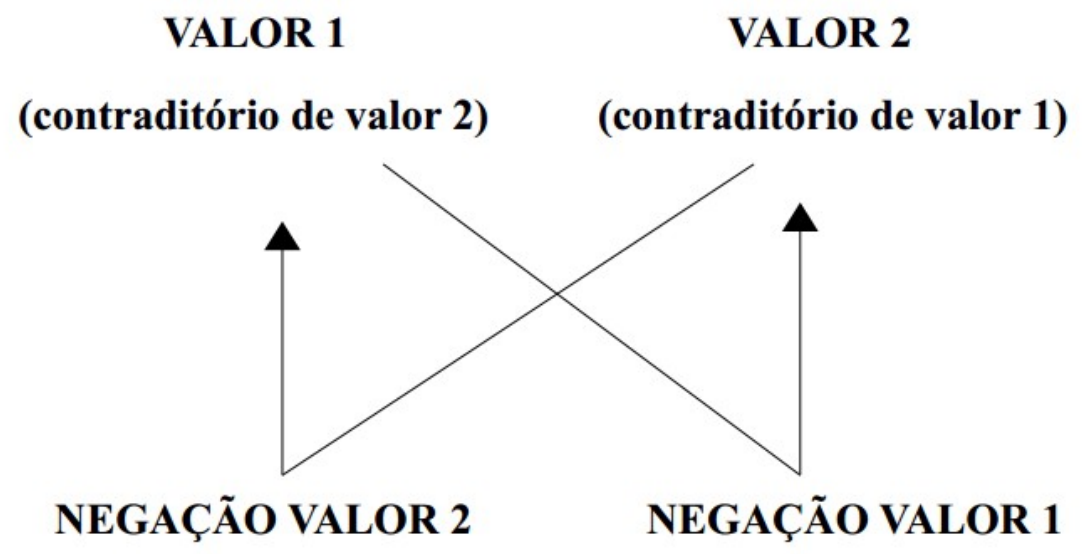

Fonte: Maria Estela Silva Andrade, 2019

Fiorin (2009) explica que falar em percurso gerativo implica em falar sobre plano de conteúdo, e como um plano de conteúdo necessita obrigatoriamente de um plano de expressão para ser veiculado, independente desse ser verbal, pictórico ou de outra forma, concordamos com o autor quando esse define o percurso gerativo de sentido como um simulacro metodológico da produção de um conteúdo e interpretação de seu significado (FIORIN, 2009, p. 44), e, dessa forma, nos sentimos confiantes na adesão do método.

\subsection{Seleção do Corpus}

Para que possamos identificar entre a vasta gama de produções do cinema brasileiro obras de ficção científica, o primeiro passo consiste em estabelecermos parâmetros de seleção. Embora a temática dos filmes seja um aspecto importante para esta pesquisa, concordamos com o pesquisador Robert Stam (2003, p. 28) quando esse afirma: “[...] a temática é o critério mais débil para o agrupamento genérico por não levar em consideração a forma como o tema é tratado"; logo, não vamos única e exclusivamente por este caminho e também nos pautamos na definição de ficção científica estabelecida no primeiro capítulo dessa dissertação, em que a FC é compreendida como um gênero em que a verossimilhança é validada pela lógica cognoscitiva de uma ciência extrapolada, e que apresenta algum tipo de inovação histórica fundamental para o desenvolvimento da narrativa. 
Assim como Kellner (2001), acreditamos que analisar obras culturais em suas matrizes de produção e recepção nos auxilia a entender seus possíveis efeitos e usos, bem como contornos e tendências, dentro de seus contextos sociopolíticos. Convém salientarmos que devido aos diversos processos e dificuldades pelas quais passam as produções cinematográficas brasileiras, que muitas vezes atrasam a etapa de distribuição das obras, decidimos pautar nossas escolhas pelas datas de produção dos filmes (desde o desenvolvimento do roteiro à pós-produção), ao invés dos anos de lançamento, assim, temos mais confiança de que seu discurso foi formulado no mesmo contexto por nós estudado. Dessa forma, optamos pela seleção de dois filmes com diferentes condições de produção e que visam públicos distintos, são eles: O Homem do Futuro (TORRES, 2011), produzido em 2010, e Branco Sai, Preto Fica (QUEIRÓS, 2014), produzido no ano de 2013.

O Homem do Futuro é um longa-metragem brasileiro que une os gêneros ficção científica, comédia e romance. Escrito e dirigido por Cláudio Torres, a produção chegou às salas de cinema em setembro de 2011, com distribuição da Paramount, e atingiu número de espectadores/as de pouco mais de 1.200 .000 pessoas, de acordo com dados do Observatório Brasileiro do Cinema e do Audiovisual (2018b). Podemos dizer que este filme é um clássico exemplo da cultura da mídia, por ter sido feito com base num modelo de produção em massa, voltado a um público amplo, de acordo com gêneros e seguindo normas, códigos e fórmulas convencionais (KELLNER, 2001), por meio da associação de duas grandes produtoras nacionais, Conspiração e Globo Filmes, com vistas de lucro e, devido a isso - como ressalta Champagnatte (2014, p. 9) de maneira generalista ao discorrer acerca da presença de empresas no processo de produção de um filme -, com restrições quanto a seu discurso, preferência por enredos com maior apelo popular e atores/atrizes já conhecidos/as do grande público.

Por outro lado, Branco Sai, Preto Fica é uma obra autoral e com clara proposta de ataque político, assim como toda a filmografia do diretor Adirley Queirós. Diferente de O Homem do Futuro, que teve seu orçamento estimado em 8 milhões de reais (CAMARGO, 2011), entre investimentos públicos e privados, e distribuição em 291 salas de cinema somente no Brasil (OBSERVATÓRIO BRASILEIRO DO CINEMA E DO AUDIOVISUAL, 2018b), Branco Sai, Preto Fica, vencedor do Festival de Brasília em 2014, foi produzido pela pequena produtora do próprio diretor, 5 da Norte, junto ao Coletivo de Cinema em Ceilândia (CEICINE) com o valor modesto de 221 mil reais vindos de um edital público destinado à 
produção de filmes documentários (LOPES, 2015), e foi distribuído em apenas 14 salas de cinema (no entanto, diversas exibições alternativas pelo país foram organizadas).

Acreditamos que por virem de atores sociais distintos e, de certa forma, opostos, ao realizarmos a análise de ambos os filmes pela mesma metodologia, é possível obter um resultado mais fiel à realidade, mesmo que não totalizante, sobre a difusão do mito da nação do futuro pelo cinema brasileiro recente. 


\section{BRASIL, O PAÍS DO FUTURO}

Como todo conceito, o "progresso", no sentido de desenvolvimento, não pode ser entendido fora de seu contexto histórico. A noção de progresso é recente na história da humanidade, pois necessitou da passagem de determinismos mitológicos e religiosos para um ideal antropocentrista; logo, na cultura ocidental, data do Renascimento europeu um primeiro esboço desse conceito, baseado na busca pela perfeição estética e na superação da decadência da Idade Média.

Porém, no mundo pós-iluminista, com o surgimento da ciência e da indústria, a noção de progresso, assim como o processo histórico, voltou-se às realizações materiais e ao aperfeiçoamento científico, com a ideia de uma acumulação. Para Wright (2007), a partir desse ideal vitoriano, grande parte das culturas ocidentais hoje crê que o aprimoramento é padronizado, independente do sistema socioeconômico ${ }^{22}$ e, antes de tudo, natural; no entanto, a mesma natureza exemplifica que esse não é acessível a todas e todos igualmente ${ }^{23}$.

Atualmente, as culturas ocidentais deixaram de lado o progresso moral e passaram a medir o progresso humano pela tecnologia. Nas palavras de Wright (2007, p. 16): “[...] o porrete é melhor do que o punho, o arco é melhor do que o porrete, a bala é melhor do que o arco. Chegamos a essa crença por razões empíricas, porque assim se deu”.

Como a FC é um gênero que se baseia nos avanços da ciência e tecnologia e/ou em mudanças sociais para a criação de realidades que se diferem da nossa - que podem ser tanto a imaginação de futuro, um presente alternativo ou alteração de fatos do passado -, podemos dizer que há sempre uma ideia de progresso envolvida para mascarar o desejo da mudança, mesmo que seja para que o descartemos como opção. Ao citar Raymond Williams, Maria Elisa Cevasco (2018, informação verbal) ${ }^{24}$ explica que nossos desejos são delimitados, criados e estimulados pela conjuntura histórica na qual nos encontramos, logo, podemos dizer que o estudo de narrativas de ficção científica nos permite ampliar nossa compreensão de determinados tempos.

22 Contudo, para Wright (2007), o colapso da URSS levou muitos a crer na existência de apenas um caminho ao progresso, que justifica a acumulação do sistema capitalista.

23 “O próprio surgimento na Terra de criaturas que possam esboçar um tal pensamento sugere que o progresso é uma lei da natureza: o mamífero é mais veloz que o réptil, o macaco é mais astuto que o touro e o homem é o mais inteligente de todos." (WRIGHT, 2007, p. 16).

24 Fala da pesquisadora durante o debate "Diálogos com Marx - ficção científica", ocorrido em 11 dez. 2018 , na cidade de São Paulo, com organização da Editora Boitempo, Goethe Institut São Paulo, Fundação Friedrich Ebert - Brasil, Livraria Tapera Taperá e Revista Carta Capital. 
Para Wright, o ideal de progresso tornou-se um mito no sentido antropológico:

O mito é uma organização do passado, seja real ou imaginado, em modelos que reforçam os mais profundos valores e aspirações de uma cultura... Os mitos são tão repletos de significados que nós vivemos e morremos por eles. Eles são os mapas pelos quais as culturas navegam ao longo do tempo (WRIGHT, 2007, p. 17)

Para as bases de desta pesquisa, partimos da alegação de Hall (2014) que compreende as culturas nacionais não apenas como instituições políticas, mas como discursos que organizam tanto nossas ações quanto as concepções que temos de nós mesmos. De acordo com ele, tais sentidos estão presentes nas memórias e histórias contadas sobre as nações, que conectam o presente e o passado a imagens que delas são construídas. Assim, sabemos o que é pertencer a um país (nesse caso, ser brasileiro/a) devido ao modo como um conjunto de características (a "brasilidade") veio a ser representado por essa cultura nacional, gerando, segundo Schwarz (1986), sentimentos de identidade e lealdade, ou seja, é criada toda uma mitologia.

Hall (2014) enumera algumas formas de como esse discurso mitológico é propagado e resiste ao tempo, dentre elas, ele destaca como principal a presença da narrativa na cultura da mídia, junto a narrações, literaturas nacionais e cultura popular, que fornecem: “[...] uma série de histórias, imagens, panoramas, cenários, eventos históricos, símbolos e rituais nacionais que simbolizam ou representam as experiências partilhadas, as perdas, os triunfos e os desastres que dão sentido à nação" (Ibid., p. 31). Essa conexão do indivíduo ao destino nacional - maior do que ele/a e que continua após sua morte - atribui significado e importância à sua existência (Ibidem). Em segundo lugar, ele aponta a necessidade de permanência imutável dos elementos essenciais do caráter nacional, independente das mudanças históricas (HALL, 2014, p. 32).

A introdução de Stuart Hall nos aproxima do pensamento de Mary Elizabeth Ginway (2005a) que em seus estudos sobre os reflexos do discurso desenvolvimentista do período ditatorial na literatura brasileira de ficção científica alega que os mitos nacionais são peças chaves no entendimento do processo de modernização, pois oferecem, segundo ela: "senso de continuidade e servem como base para a 'comunidade imaginada' do Brasil”' (GINWAY, 2005a, p. 16 $)^{25}$. Em um momento de perda de referências causada pela avassaladora

25 Aqui, a autora utiliza o termo "comunidade imaginada" no mesmo sentido usado por Benedict Anderson em seus estudos: "são imaginadas porque mesmo os membros das menores nações nunca irão conhecer a maioria dos seus companheiros, encontrá-los, ou mesmo ouvi-los, ainda que nas mentes de cada um exista a imagem da comunhão deles." (ANDERSON, 1983, p. 6). 
experiência da mudança, esses mitos unem diferentes classes, etnias, religiões e ideologias, e entre entre eles consta o discurso da grandeza nacional que ecoa desde os tempos da colonização. Essa seria a explicação do porquê mesmo após profundas mudanças ocorridas em estruturas econômicas, sociais e políticas a partir do início da colonização portuguesa - a passagem para o sistema capitalista a partir da Revolução Industrial, em meados do século XVIII, sua expansão e aprimoramento com a $2^{\text {a }}$ Revolução Industrial, no século XVI, e a revolução tecnológica do século XX, além da proclamação da república, independência de Portugal e alternância de regimes políticos turbulentos - o discurso continuasse sendo sustentado.

Contudo, foram necessárias adaptações. No século XX já não era mais possível que a concepção de país do futuro estivesse em uma nação agroexportadora, logo, medidas desenvolvimentistas passaram a ser adotadas pelos governos brasileiros a partir de 1930, com Getúlio Vargas ${ }^{26}$, passando por Juscelino Kubistchek e a ditadura militar, até serem substituídas nas décadas finais do mesmo século por medidas neoliberais (FONSECA, 2004).

Segundo Bielschowsky (1995, p. 7), o desenvolvimentismo é:

[...] uma ideologia de transformação da sociedade brasileira definida pelo projeto econômico que se compõe dos seguintes pontos fundamentais:

a) a industrialização integral é a via de superação da pobreza e do subdesenvolvimento brasileiro; b) não há meios de alcançar uma industrialização eficiente e racional no Brasil através das forças espontâneas do mercado; por isso, é necessário que o Estado a planeje;

c) o planejamento deve definir a expansão desejada dos setores econômicos e os instrumentos de promoção dessa expansão; e d) o Estado deve ordenar também a execução da expansão, captando e orientando recursos financeiros, e promovendo investimentos diretos naqueles setores em que a iniciativa privada seja insuficiente.

Fonseca (2004, p. 226) adiciona a essas características um amplo nacionalismo, que pode ir desde o ufanismo conservador até o rompimento radical e unilateral com o capital estrangeiro, e vai além:

Este [o desenvolvimentismo] não pode ser reduzido, como fenômeno histórico, a simples medidas de expansão da demanda agregada a manifestações nacionalistas ou a reivindicações corporativistas em defesa da indústria. [...] o salto maior ocorre quando o conjunto de ideias, como toda boa ideologia, passa

26 Segundo Fonseca (2004), a primeira experiência histórica desenvolvimentista ocorrida no Brasil data a Primeira República, durante o governo Vargas na presidência do Estado do Rio Grande do Sul, em 1928, porém, aqui, levaremos em conta experiências em âmbito nacional. 
a justificar a si mesmo, ou seja, quando há a defesa explícita de que a principal tarefa do governo consiste na busca do desenvolvimento econômico, que este é seu principal dever, seu objetivo central, no limite, sua razão de ser (FONSECA, 2004, p. 227).

De acordo com ele (Ibid., 2004), desde os tempos da colonização e do Império já era possível detectar algumas dessas características, porém, de forma fragmentada. Nesse sentido, Fonseca, Cunha e Bichara alegam:

Os autores que interpretam o governo Lula como uma retomada, mesmo em nova forma, do desenvolvimentismo, tendem a argumentar, implícita ou explicitamente, que este pode, via de regra, ser entendido como fenômeno embedded na formação social brasileira, com raízes históricas profundas, de modo que o interregno das duas últimas décadas do século $\mathrm{XX}$ pode ser visto como a interrupção temporária de uma tendência que, mediante certas condições permissivas, aflora novamente. (FONSECA; CUNHA; BICHARA, 2013, p. 410).

É curioso notarmos como desde de o início do desenvolvimento da FC no Brasil, o discurso da "grande nação brasileira" já se encontrava explicitamente presente, como demonstra o trecho a seguir, retirado da primeira obra de ficção científica brasileira, publicada em 1875, “O Doutor Benignus":

\begin{abstract}
À bandeira brasileira, que se desfralda inundada de luz sobre nossas cabeças! [...] Quando um dia os desertos que vamos atravessar, as selvas por onde temos de embrenhar-nos, as cordilheiras que havemos de transpor e os rios imensos que teremos de navegar, forem o teatro de uma civilização gigante e esplêndida, esta bandeira, tantas vezes gloriosa com o batismo de sangue das batalhas, tremulará então para sempre ainda mais esplendorosa do que hoje nos campos de combate do trabalho, nas oficinas da indústria e nos templos sacrossantos da religião e da paz! [...] Como não acreditar que em algum ponto desta região predestinada, na junção das duas Américas, no caminho da Europa e Ásia, será capital futura do mundo? [...] a bandeira que será destinada talvez a arvorar-se no gigantesco capitólio da metrópole do futuro! (ZALUAR, 1994, p. 120).
\end{abstract}

Aqui, o uso dos termo "predestinada" reforça a certeza de que é apenas questão de tempo até que o Brasil se torne "uma civilização gigante e esplêndida", a "capital do mundo".

\title{
4.1 Governos Lula e Dilma Rousseff
}

Com essas características em vista, identificamos nas gestões petistas do governo federal (2003 - 2016) similaridades que podem ser interpretadas como uma retomada de 
políticas desenvolvimentistas, porém com uma nova roupagem adaptada ao século XXI, que aqui chamaremos de "ensaio desenvolvimentista"27. No entanto, Lamoso explica que as características desenvolvimentistas não foram adotadas de imediato pelo governo:

\begin{abstract}
Estratégias neodesenvolvimentistas foram mais claramente elaboradas no segundo governo Lula da Silva (2006 - 2010). No primeiro mandato, [apostouse em] políticas pouco criativas e mais afastadas do espectro político proposto pela esquerda. No segundo mandato foi colocada em prática uma maior intervenção do Estado no setor produtivo, estratégias de recuperação da infraestrutura instalada e da formação de capital. [...] Políticas de planejamento de longo prazo foram retomadas. [...] [A] política industrial, se distancia das práticas anteriormente adotadas, baseadas na utilização do protecionismo tarifário, incentivos/ subsídios fiscais, esquemas de incentivo de duração ilimitada. (LAMOSO, 2012, p. 397)
\end{abstract}

Entre os anos 2000 e 2011 - final da gestão do PSBD, governo de Lula e início da gestão de Dilma Rousseff, também do PT -, o PIB brasileiro cresceu em média 4\% ao ano, sendo que em 2010, o crescimento foi de 7,5\%, após recessão em 2009, e a inflação ficou controlada com taxa anual média de 5,4\% ao ano, segundo dados levantados por Cruz et al. (2012) e divulgados pelo Banco Nacional de Desenvolvimento Econômico e Social (BNDES). Junto a isso, os economistas Fonseca, Cunha e Bichara (2013, p. 408) destacam que a junção de fatores como o aumento de investimentos em projetos sociais por parte do governo federal, a queda na taxa de desemprego e uma forte expansão do crédito, ajudou a manter o clima de estabilidade no país. Segundo André Singer (2015), ainda que com algumas dificuldades causadas pela crise econômica internacional, parte do primeiro mandato da expresidenta Dilma Rousseff (2011-2013) continuou, do ponto de vista programático, com características do ensaio desenvolvimentista, que até então parecia dar certo. A aposta no sucesso brasileiro era tanta que foi assunto de um editorial de catorze páginas na revista The Economist (2009), com a icônica capa [figura 2]:

27 Segundo Singer $(2015 ; 2016)$, nesse caso, há polêmica em torno da utilização das expressões "novo desenvolvimentismo" e "social desenvolvimentismo". Como nosso objetivo com essa pesquisa não está no mapeamento de diferenças entre os dois termos, optamos por, assim como o autor, dar preferência à expressão "ensaio desenvolvimentista". 
Figura 2 - Capa da revista The Economist (2009)*

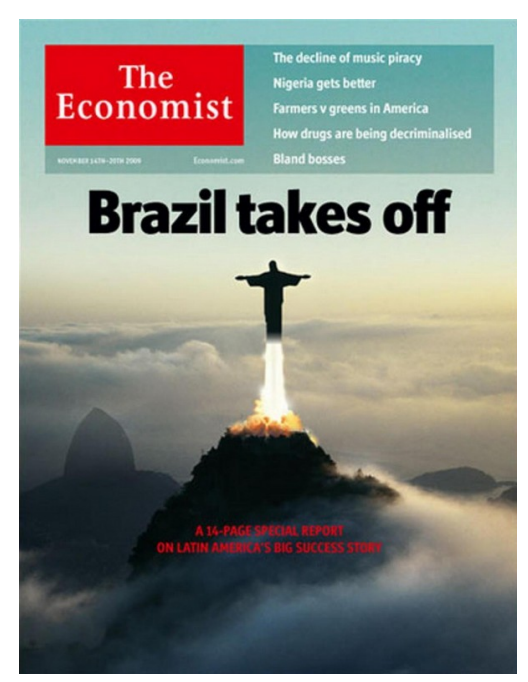

Fonte: The Economist, 2009

*Extraído do site da revista.

Mesmo com um discurso esquizofrênico, no qual ao mesmo tempo em que se proclamava um outsider demonstrava o desejo em integrar a lista de grandes potências capitalistas, o Brasil parecia estar pronto para ocupar seu lugar entre os grandes - ou, pelo menos, era o que se pensava.

Com a associação desses dados ao pensamento de Stuart Hall e à pesquisa de Elizabeth Ginway, discorridos acima neste mesmo capítulo, acreditamos que nos primeiros anos de governo petista, a melhora em indicadores econômicos e sociais - crescimento do PIB, aumento real do salário mínimo e do crédito à pessoa física, diminuição do número de desempregados, extensão do programa Bolsa Família e queda do coeficiente de Gini, para citarmos alguns exemplos - junto à presença marcante do Brasil no cenário político internacional - participação na Conferência do Clima e a atuação militar no Haiti - e em grandes eventos midiáticos internacionais (conquista da sede da Copa do Mundo de futebol de 2014 e das Olimpíadas de 2016), com associação à figura de um líder carismático como Lula da Silva, ajudaram a reforçar o imaginário nacional mitológico e o sentimento de que o Brasil era digno de um lugar entre os grandes.

Ao nosso ver, alguns dos exemplos citados acima exemplificam que o resgate do sentimento de grandeza também se mostrou por meio de ações imperialistas, tanto em suas 
relações diplomáticas, principalmente com países da América Latina, como na forma de políticas econômicas de incentivo à internacionalização de empresas ${ }^{28}$. Concordamos com Deo quando esse afirma:

Nos parece correta a tese que aponta para a atuação da diplomacia brasileira como um dos principais instrumentos [...] de inserção do imperialismo brasileiro no mundo. Nesse sentido, durante o primeiro mandato de Luís Inácio, o governo brasileiro capturou de maneira precisa (do ponto de vista burguês) as possibilidades que o aquecimento da economia mundial proporcionou às exportações brasileiras, não só de produtos manufaturados como também de capitais.[...] Para tanto, [...] o governo - e em especial, o presidente Lula deveria consolidar o papel de "líder regional" na América do Sul, dirigindo a economia do subcontinente no atual processo de internacionalização do capital. (DEO, 2012, p. 134)

Segundo o autor, esse posicionamento elucida motivações que levaram o país a adotar certos posicionamentos em suas relações internacionais, como seu protagonismo em fóruns do G20, o envio de tropas ao Haiti, a suspensão das negociações para a formação da Alca, as dificuldades impostas à formação da Rodada de Doha, a candidatura a uma cadeira no Conselho de Segurança da Organização das Nações Unidas (ONU), além de assumir o papel de interlocutor em conflitos internacionais (DEO, 2012).

Porém, de acordo com Singer (2015), com as mudanças na política econômica a partir de 2013 para combate à inflação (aumento do juros pelo Banco Central, cortes no investimento público, privatizações, entre outros), as políticas desenvolvimentistas passaram a atuar como uma resistência enfraquecida perante ao choque neoliberal. 
Figura 3 - Capa da revista The Economist (2013)*

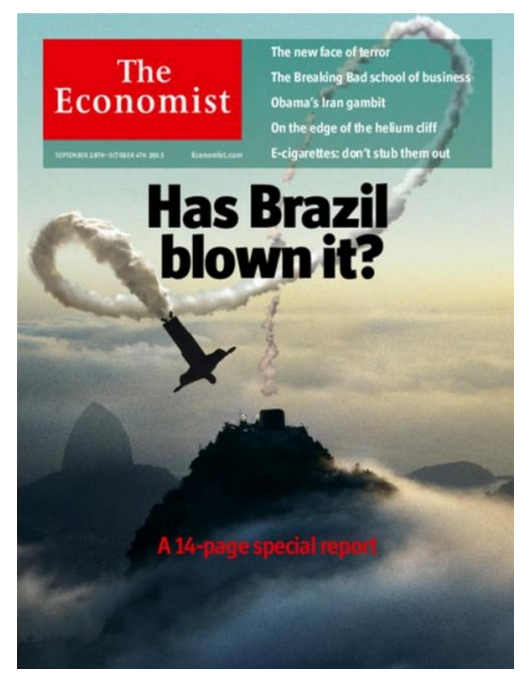

Fonte: The Economist, 2013.

*Extraído do site da revista.

No mesmo ano, uma onda de manifestações populares tomou conta do Brasil. Apesar de a reivindicação inicial ser contra o reajuste das tarifas dos transportes públicos, rapidamente foi expandida para diversas outras demandas. Para o sociólogo Ruy Braga (2013, p. 53), as causas da insatisfação popular têm suas origens nas políticas de modernização do início dos anos 2000, baseadas no favorecimento do grande empresariado e no precariado - parcela mais precarizada do proletariado clássico, formada por um setor da classe trabalhadora pressionado pelo aumento da exploração econômica e pela ameaça da exclusão social (BRAGA, 2012) junto à intensificação da crise econômica internacional, que serviu como desacelerador ao ritmo de crescimento do país. Menos de três anos após as jornadas de junho de 2013, o Brasil atingiu uma crise política que culminou com o impeachment de Dilma Rousseff. O mito do país do futuro tornou-se insustentável. 
Figura 4 - Capa da revista The Economist (2016)*

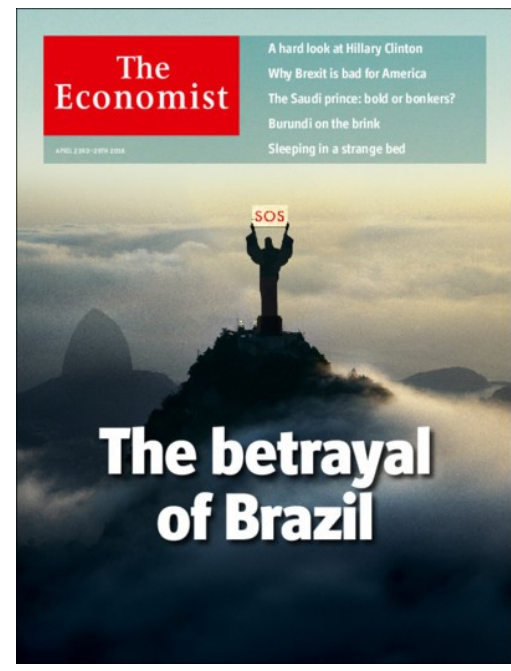

Fonte: The Economist, 2016.

*Extraído do site da revista. 


\section{ANÁLISES}

A seguir, consta a análise dos filmes selecionados de acordo com a metodologia descrita no capítulo três dessa dissertação.

\subsection{O Homem do Futuro}

A narrativa se inicia em 2011, no Rio de Janeiro, e conta a história de João, mais conhecido como Zero, um brilhante físico e professor universitário, único no mundo com uma pesquisa ligada a um acelerador de partículas, devido aos investimentos de sua amiga Sandra na criação de um fundo de tecnologia para ajudá-lo. Junto a seu melhor amigo, Panda, Zero tenta desenvolver uma nova forma de energia. No entanto, ele é infeliz e frustrado por há 20 anos ter sido publicamente ridicularizado em uma festa por Helena - amor de sua vida que se tornou uma famosa modelo internacional -, devido a uma armação de Henrique.

Ao ser tido como louco pelos investidores do fundo e ameaçado de ser substituído na liderança da pesquisa pelo cientista americano Steve Webbs, tomado pela raiva e pensando em Helena, Zero tenta provar sua teoria ligando o acelerador de partículas e se colocando no centro da ação. Para sua surpresa, ele viaja no tempo para 22 de novembro de 1991, dia em que ocorreu seu maior trauma.

Com essa oportunidade, o cientista manipula os acontecimentos para que sua personalidade jovem - até então conhecida por João - e Helena e não se separem, além de fornecer informações à versão jovem de Panda para garantir a riqueza de ambos no futuro. Por ter interferido na história, Zero não existe mais, assim, suas moléculas são desintegradas e rearranjadas em uma versão alternativa de 2011.

Agora Zero é o homem mais rico do Brasil graças a seus investimentos na bolsa de valores, já que sabia quando todos os fatos de impacto econômico iriam ocorrer. No entanto, praticou atitudes mesquinhas para com seu antigo amigo e sócio (Panda, agora conhecido como Otávio). Zero descobre que foi casado diversas vezes e divorciou-se de todas suas esposas, sendo que uma delas, Helena, ele foi capaz de mandar à prisão por ciúme. $\mathrm{Na}$ área científica, comprou um projeto de acelerador de partículas desenvolvido por Sandra, porém, o manteve trancado em um cofre. Ao presenciar tais consequências sob o olhar da personalidade que viaja no tempo (a qual, por motivos de diferenciação, chamaremos a partir 
de agora de Zero Bondoso), ele se dá conta de que precisa novamente ir a 1991 e impedir sua personalidade que viajou no tempo pela primeira vez (Zero Maléfico) de alterar o destino. Junto a Otávio, numa quantidade de tempo que não nos é informada, ele tira o projeto de Sandra do papel e viaja no tempo mais uma vez.

Enquanto João, sem saber de nada, se diverte na festa, Zero Maléfico se recusa a desfazer a interferência e, com a ajuda do Otávio, que também viajou no tempo, prende Zero Bondoso em um porão e sequestra Helena e João. Amarrado, Zero Bondoso se dá conta de que todo o ocorrido estava previsto para acontecer, sendo a personalidade que primeiro viajou no tempo já uma consequência de todas essas interferências. Auxiliado pela personalidade jovem de Sandra, Zero Bondoso derrota Zero Maléfico e faz um acordo com Helena de procurá-la em 20 anos.

Reconfigurado em 2011, Zero Bondoso destrói a máquina do tempo e corre ao aeroporto para se encontrar com Helena, que está à sua espera. Por fim, ele é julgado pelo crime de ter destruído pesquisa e é expulso da comunidade científica; no entanto, o acordo feito com Sandra no passado é revelado e a fortuna do fundo de tecnologia é dividida entre todos/as.

A tabela abaixo esquematiza a disposição das personagens na narrativa de acordo com os anos [Quadro 2]:

Quadro 2 - Disposição das personagens em O Homem do Futuro

\begin{tabular}{|l|c|c|c|c|}
\hline & $\begin{array}{c}2011 \text { (inicial e } \\
\text { final) }\end{array}$ & $\begin{array}{c}1991\left(1^{\mathrm{a}}\right. \\
\text { intervenção) }\end{array}$ & 2011 Alternativo & $\begin{array}{c}1991\left(2^{\mathrm{a}}\right. \\
\text { intervenção) }\end{array}$ \\
\hline $\begin{array}{l}\text { Zero/ Zero } \\
\text { Bondoso }\end{array}$ & $\mathrm{X}$ & $\mathrm{X}$ & $\mathrm{X}$ & $\mathrm{X}$ \\
\hline João & & $\mathrm{X}$ & & $\mathrm{X}$ \\
\hline Zero Maléfico & $\mathrm{X}$ & $\mathrm{X}$ & $\mathrm{X}$ & $\mathrm{X}$ \\
\hline Helena & $\mathrm{X}$ & $\mathrm{X}$ & & $\mathrm{X}$ \\
\hline Panda & & & $\mathrm{X}$ & $\mathrm{X}$ \\
\hline Otávio & $\mathrm{X}$ & $\mathrm{X}$ & $\mathrm{X}$ & $\mathrm{X}$ \\
\hline Sandra & & $\mathrm{X}$ & $\mathrm{X}$ & $\mathrm{X}$ \\
\hline Henrique & & & \\
\hline
\end{tabular}

Fonte: Maria Estela Silva Andrade, 2019 


\subsubsection{Análise de O Homem do Futuro}

De forma simplificada, podemos dizer que a narrativa conta a história de Zero, um cientista que, devido a uma rejeição amorosa no passado, vive infeliz no presente e preenche o campo afetivo de sua vida com sua pesquisa científica, agora ameaçada de controle por um estrangeiro. Ao tentar reverter a situação, Zero se depara com uma viagem no tempo que o permite modificar o próprio passado para alcançar seu ideal de felicidade, constituído pela junção de dinheiro e o amor, representado pela figura de Helena. Contudo, ao priorizar o enriquecimento e não agir de forma ética com as pessoas ao seu redor, Zero não atinge seu objetivo. Ele, então, volta ao passado novamente, agora para corrigir seus erros, priorizando os valores ética e amor, para, por fim, ser recompensado com o que tanto almejava.

Sob este ponto de vista, entendemos que o programa narrativo maior de Zero é alcançar sua felicidade, essa dividida de maneira hierárquica, em que sua união com Helena ocupa o primeiro posto e o sucesso da pesquisa científica vêm logo abaixo. Assim, identificamos a oposição fundamental entre os valores felicidade (eufórico) e infelicidade (disfórico), desenvolvida sob a forma das leituras temáticas do amor que resiste ao tempo e do respeito aos limites éticos. Dessa forma, descrevemos seu percurso no seguinte quadrado semiótico [figura 5]:

Figura 5 - Percurso narrativo de Zero

\section{INFELICIDADE $\quad$ FELICIDADE}

\section{NÃO FELICIDADE}

\section{NÃO INFELICIDADE}

Fonte: Maria Estela Silva Andrade, 2019

Observamos que há três elementos de grande importância a Zero: o amor, o dinheiro e a ciência, cada um em seu momento. Esses se encontram dispostos da seguinte forma ao longo 
da narrativa: no início, por mais que tente negar, tudo à volta de Zero (sujeito) o faz lembrar de Helena (objeto valor) e dos infortúnios do passado; ele sabe que sua única chance de ser feliz é com ela ao seu lado, então, o objetivo de seu percurso é traçado: ficar com Helena. Na etapa seguinte, o sujeito é dotado das competências necessárias (saber e poder) para desenvolver seu programa narrativo. Neste caso, ele adquire o objeto modal do poder (a máquina do tempo), que o permite voltar ao passado e refazer sua história.

Ao longo da execução do programa narrativo (etapa da performance), os objetivos de Zero não se concretizam (a versão alternativa de 2011 é uma falsa escapatória da infelicidade, ele possui dinheiro mas não o amor de Helena), ele, então, ao perceber que priorizou os valores errados, volta à etapa de competência e adquire o objeto modal do saber, a consciência de que o dinheiro e o poder corrompem e não trazem felicidade, e que o amor e a amizade devem vir acima de tudo. Ao completar a performance de forma correta, a sanção do sujeito é ficar em união com Helena, e atingir o objetivo inicial de seu percurso, a felicidade, como mostra a tabela abaixo [Quadro 3]: 
Quadro 3 - Disposição dos elementos no percurso de Zero

\begin{tabular}{|c|c|c|c|c|}
\hline & ETAPA & ACONTECIMENTO & $\begin{array}{c}\text { ELEMENTOS } \\
\text { PRESENTES }\end{array}$ & PERCURSO \\
\hline 2011 (inicial) & Manipulação & $\begin{array}{l}\text { O sonho, a revista e as } \\
\text { acusações de Panda } \\
\text { fazem Zero } \\
\text { constantemente se } \\
\text { lembrar de Helena. }\end{array}$ & \multirow[t]{3}{*}{$\begin{array}{l}\rightarrow \text { Ciência } \\
\rightarrow \text { Amør } \\
\rightarrow \text { Đinheire }\end{array}$} & \multirow[t]{2}{*}{ Infelicidade } \\
\hline 2011 (inicial) & Competência & $\begin{array}{l}\text { Criação da máquina do } \\
\text { tempo. }\end{array}$ & & \\
\hline $\begin{array}{c}1991\left(1^{\mathrm{a}}\right. \\
\text { interferência) }\end{array}$ & \multirow{3}{*}{ Performance } & $\begin{array}{l}\text { Volta a } 1991 \rightarrow \\
\text { interferências no } \\
\text { passado para ter amor, } \\
\text { dinheiro e poder. }\end{array}$ & & \multirow{3}{*}{ Não infelicidade } \\
\hline 2011 alternativo & & $\begin{array}{l}\text { Rejeita o amor para ter } \\
\text { mais dinheiro, porém } \\
\text { percebe que tal escolha } \\
\text { o leva para a } \\
\text { infelicidade } \\
\text { novamente. }\end{array}$ & $\begin{array}{l}\rightarrow \text { Ciência } \\
\rightarrow \text { Amør } \\
\rightarrow \text { Dinheiro }\end{array}$ & \\
\hline $\begin{array}{c}1991\left(2^{\mathrm{a}}\right. \\
\text { interferência) }\end{array}$ & & $\begin{array}{l}\text { Volta a } 1991 \rightarrow 2^{\mathrm{a}} \\
\text { interferência no } \\
\text { passado para ter amor e } \\
\text { dinheiro }\end{array}$ & $\begin{array}{l}\rightarrow \text { Ciência } \\
\rightarrow \text { Amor } \\
\rightarrow \text { Einheiro }\end{array}$ & \\
\hline 2011 (final) & Sanção & $\begin{array}{l}\text { Destrói a máquina do } \\
\text { tempo, fica com } \\
\text { Helena, enriquece e é } \\
\text { expulso da comunidade } \\
\text { científica. }\end{array}$ & $\begin{array}{l}\rightarrow \text { Eiêneia } \\
\rightarrow \text { Amor } \\
\rightarrow \text { Dinheiro }\end{array}$ & Felicidade \\
\hline
\end{tabular}

Fonte: Maria Estela Silva Andrade, 2019

Por ser uma produção Globo Filmes, não podemos deixar de notar, antes de tudo, a adoção de padrões presentes em telenovelas da Rede Globo de Televisão, muito populares no Brasil e responsáveis pela alfabetização audiovisual de grande parte da população. Segundo Champagnatte (2014, p. 10):

Os valores explícitos nesses filmes [produções Globo Filmes] são bem semelhantes aos trabalhados em novelas da TV Globo, como a construção maniqueísta dos personagens e o desenvolvimento de seus enredos com base numa estrutura simples. [...] Os espectadores, portanto, já familiarizados com a linguagem da novela, não terão dificuldades em compreender a linguagem dos 
filmes produzidos nesses moldes lineares.

No nível discursivo do percurso gerativo de sentido, ao prestarmos atenção aos figurinos e caracterização das personagens, nos damos conta de que logo no início (2011 inicial), a expressão facial cansada de Zero, seu mau humor, ombros arqueados ao andar e roupas desalinhadas e amassadas indicam uma pessoa estressada e descontente, algo que nos é confirmado durante sua aula numa universidade privada [figura 6]. Junto ao flashback do ano de 1991 que mostra Zero como um clássico nerd de filmes da cultura pop (inteligente, gago, tímido e apaixonado pela garota mais bela e popular [figura 7]), é automático o associarmos à típica figura de um perdedor, mesmo quando nos é revelada sua genialidade. Em contraste, Sandra, no papel de executiva, vestida com roupas formais e salto alto, é a figura associada ao dinheiro e ao poder, aspecto confirmado por sua repressão à ousadia de Zero por ter realizado testes não autorizados com o acelerador de partículas, cujos recursos vêm de investimentos privados em um fundo de tecnologia montado por ela [figura 8].

Figura 6 - Frame do filme O Homem do Futuro, Zero em 2011 "original”

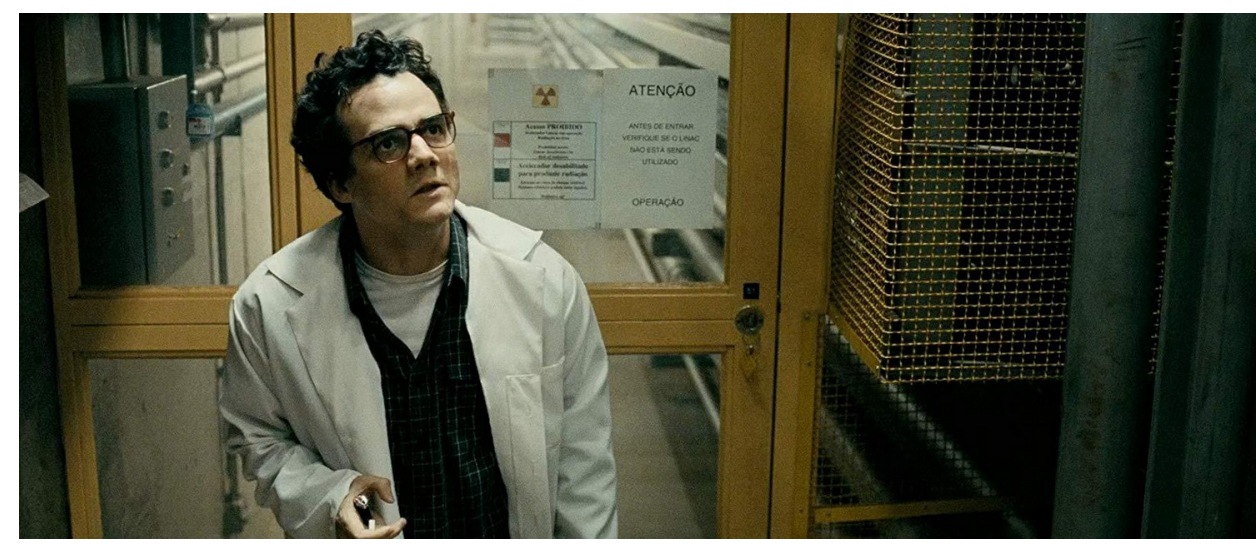

Fonte: TORRES, 2011 
Figura 7 - Frame do Filme O Homem do Futuro, João com Helena, antes de tornar-se Zero, em 1991

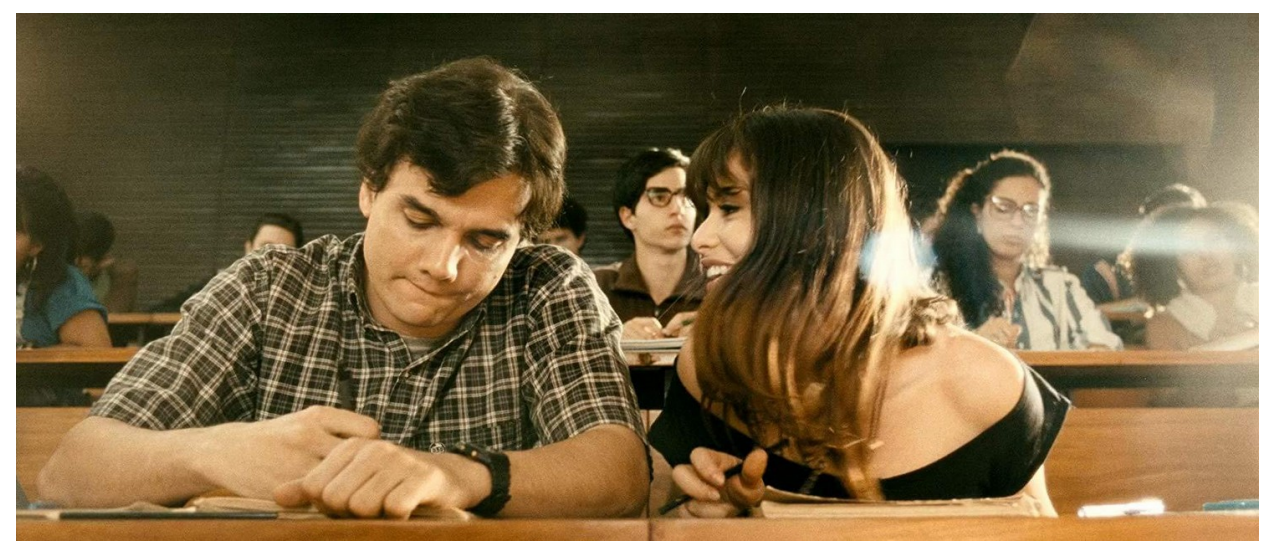

Fonte: TORRES, 2011

Figura 8 - Frame do Filme O Homem do Futuro, Sandra e Zero discutem no laboratório

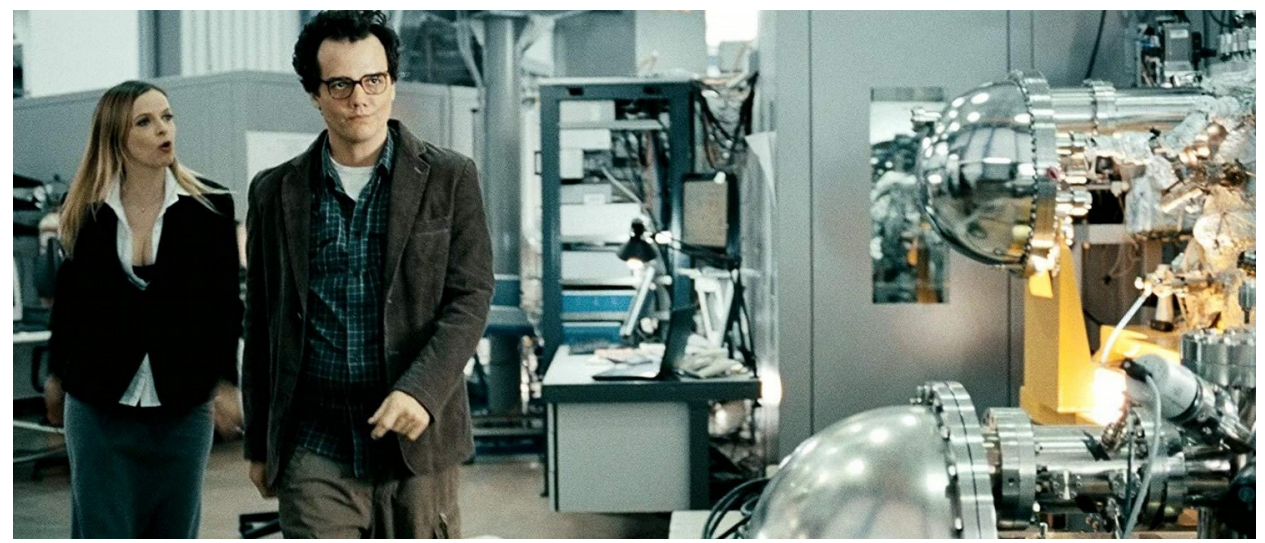

Fonte: TORRES, 2011

No entanto, na versão alternativa de 2011, quando Zero enriquece, sua caracterização é oposta àquela de 20 anos, ele apresenta postura mais ereta, ternos finos e cabelo penteado; aqui é ele quem detém o poder [figura 9]. A presença de Henrique (antissujeito responsável pelo infortúnio de Zero, que apresenta apenas características mesquinhas, preza pelo enriquecimento pessoal e é contra o amor) nesse tempo, como assessor pessoal do protagonista, é outro forte indício de um caminho que não deve ser seguido.

Já na sequência final, ao caminhar com Panda e Helena para fora do tribunal (que imita uma corte estadunidense), antes de saber que está rico, Zero apresenta um figurino com características duais mas de outra forma: veste terno mais simples, sua postura está mais 
relaxada e seu cabelo levemente desarrumado [figura 10].

É interessante notarmos que as características levantadas até aqui mobilizam valores que, apesar de opostos (sucesso [dinheiro; solidão] x fracasso [ciência; frustração]), são ambos disfóricos, o que torna possível como leitura do filme a mensagem de que a solução (felicidade) é encontrada no equilíbrio.

Figura 9 - Frame do filme O Homem do Futuro, Zero na versão alternativa de 2011

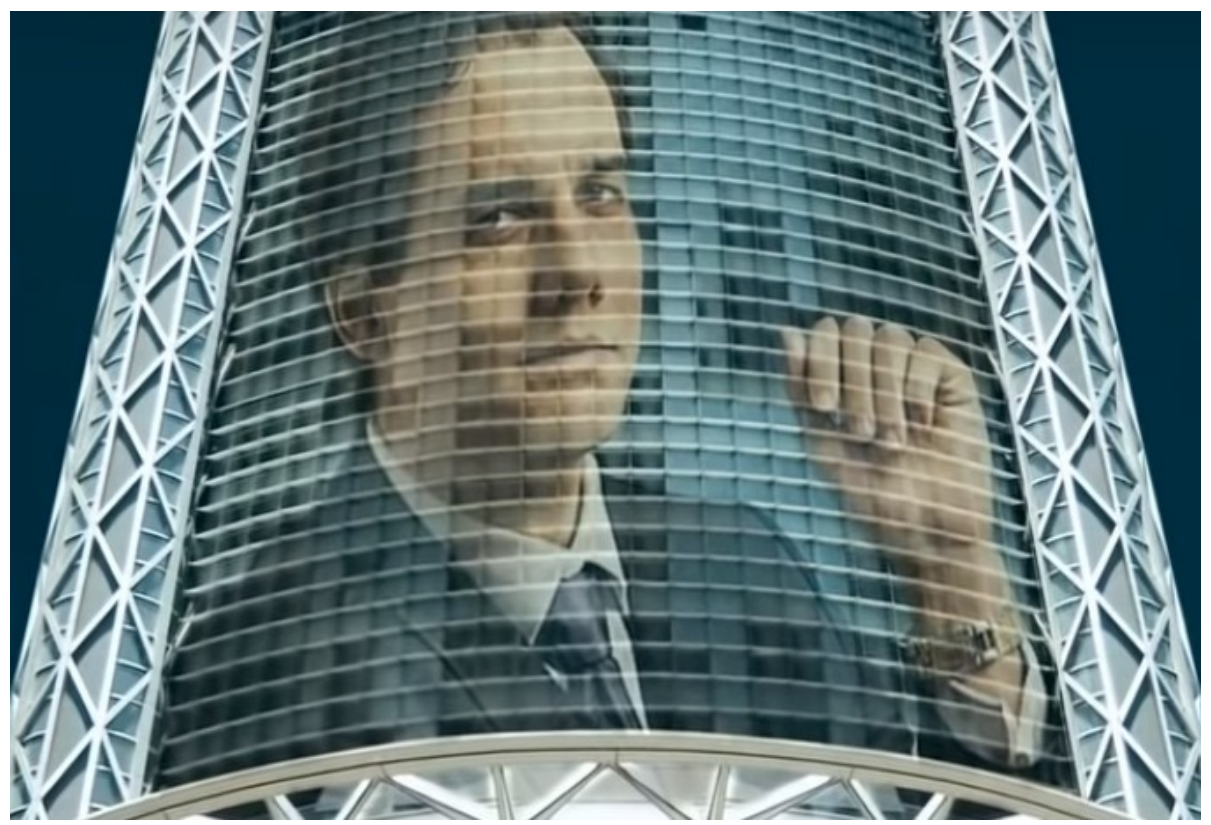

Fonte: TORRES, 2011

Figura 10 - Frame do filme O Homem do Futuro, Zero, ao sair da corte, com Panda e Helena.

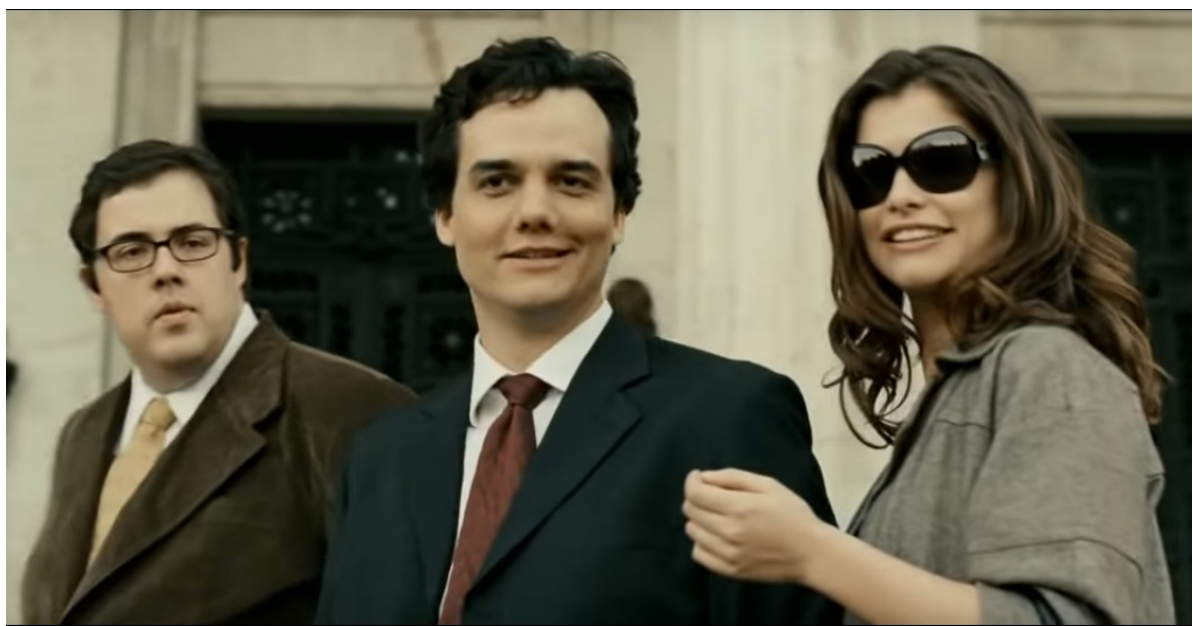

Fonte: TORRES, 2011 
Mudanças na espacialização e na fotografia de acordo com a cronologia também nos chamam a atenção. Em 1991, pela trama se desenrolar em uma festa universitária à fantasia e em um porão, os ambientes tendem a ser escuros, os cenários estão sempre repletos de artefatos e/ou pessoas e há uma variedade de cores, seja em objetos ou nas roupas das personagens e figurantes, porém essas não se destacam devido à má iluminação. De modo contrário, no 2011 alternativo é trabalhada uma fotografia de luz predominantemente branca que contrasta com os figurinos e objetos de cena, que quando também não são brancos, são da cor preta.

Ao contrário do que vemos no passado, tanto os espaços internos quanto externos, quando ligados à riqueza e à falsa felicidade de Zero, são amplos e vazios, o que somado às características da fotografia proporciona estética minimalista e tecnológica. Já a versão de 2011 que se passa antes e depois das viagens no tempo nos parece um meio termo, alternando as características de fotografia e espacialização observadas nos outros tempos. Mais atributos que reforçam a mensagem que dá preferência ao caminho do meio.

Com a articulação de todos os aspectos levantados até aqui, percebemos que o infortúnio de Zero teve início em 1991, foi mantido sob controle por 20 anos, enquanto o foco esteve em sua carreira científica, até que foi solucionado quando o progresso científico foi substituído pelo progresso financeiro; porém, nenhum deles por si só representou o verdadeiro progresso. Tal abordagem, inspirada em Douglas Kellner (2001), que em suas análises filmográficas contidas no livro "A Cultura da Mídia” (2001) enxerga reflexos das políticas econômicas adotadas em suas respectivas épocas ${ }^{29}$, nos permite fazer um exercício exploratório de comparação da narrativa ficcional com o desenvolvimento da economia brasileira no mesmo período ${ }^{30}$, em que a ciência, abordada por um viés de desumanização, corresponde à matriz econômica neoliberal seguida ao longo da década de 1990, e o alcance da felicidade, obtida pelo sucesso financeiro, à matriz do ensaio desenvolvimentista.

Entre 1991 e 1994, a economia do Brasil enfrentou um período de instabilidade econômica, marcada por hiperinflação até que fosse criado o Plano Real, caracterizado pela troca de moeda, privatizações, cortes de despesas e ajustes nas contas públicas, que resultaram em queda brusca da inflação [figura 11] - análogo ao momento em que Zero sofre humilhação e primeiros anos de sua carreira de cientista. A infelicidade e descrença da época são 
reforçadas pela presença marcante da música "Inútil"”1, da banda brasileira de rock Ultraje a Rigor, toda vez que a narrativa volta a esse tempo, colocando em xeque o mito da nação do futuro.

Figura 11 - Gráfico Inflação x Desemprego no Brasil - 1991 a 1995.

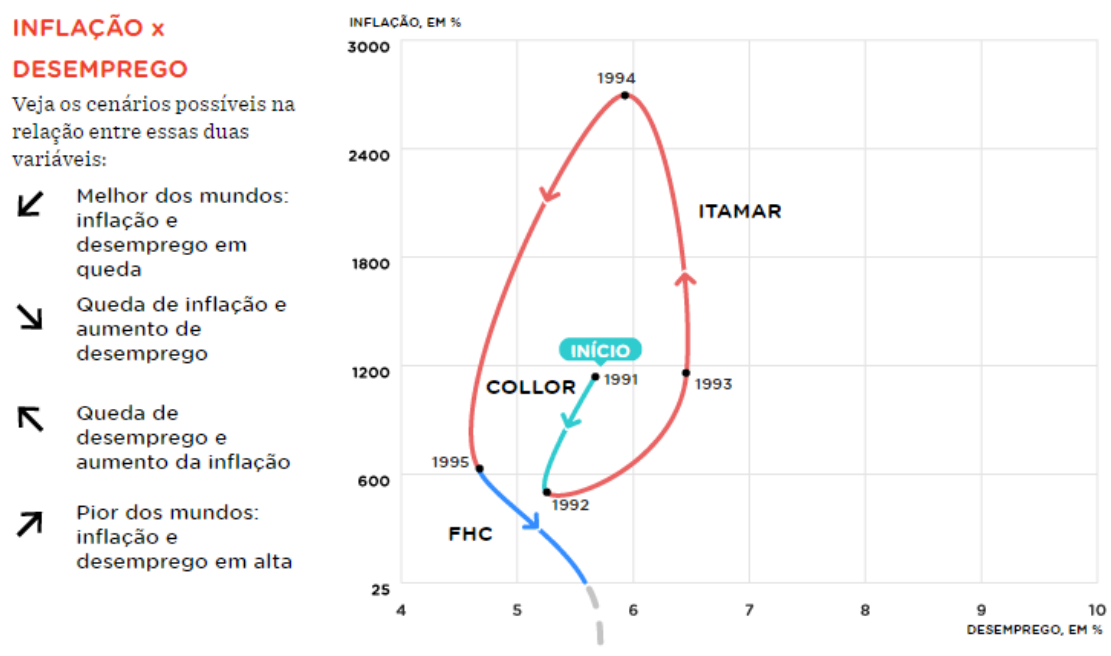

Fonte: ALMEIDA et al. (2016)

Ao longo do restante dos anos 1990, apesar de flutuações na inflação e na taxa de desemprego, a economia brasileira foi mantida sob controle se comparada ao início da mesma década (ALMEIDA et al., 2016) [figura 12] - quadro paralelo ao suposto controle de Zero sobre seus sentimentos e foco na carreira científica.

31 "A gente não sabemos escolher presidente / A gente não sabemos tomar conta da gente/ A gente não sabemos nem escovar os dente / Tem gringo pensando que "nóis' é indigente/ Inútil, a gente somos inútil" (Ultraje a Rigor, 1983). 
Figura 12 - Gráfico Inflação x Desemprego no Brasil - 1996 a 2002

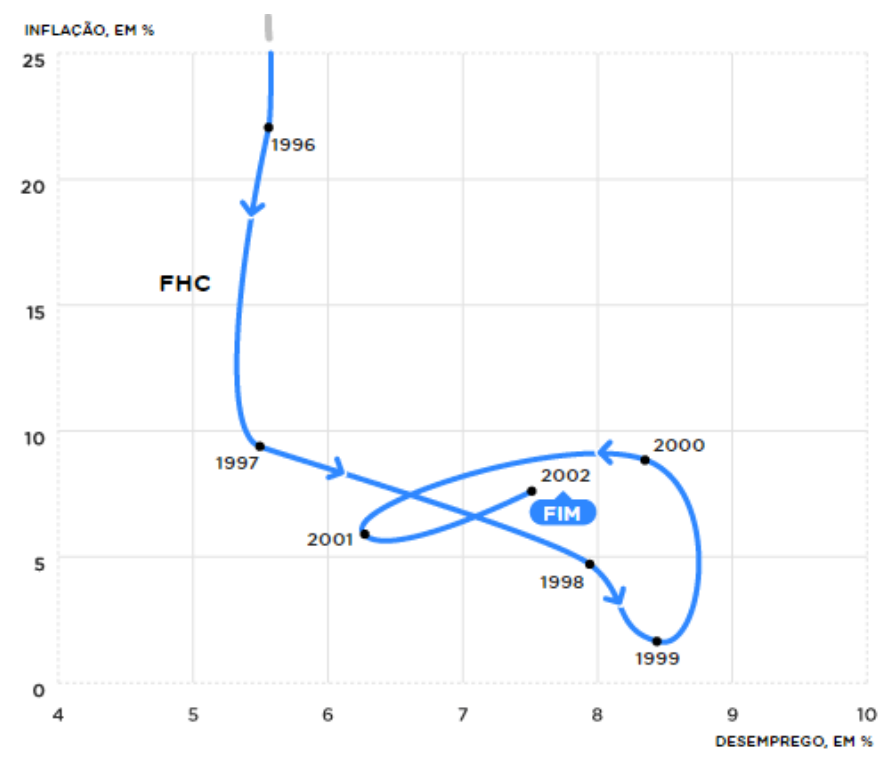

Fonte: ALMEIDA et al. (2016)

Já entre os anos de 2003 e 2007, no governo do então presidente Lula, em função do aumento da taxa de juros pelo Banco Central, a inflação teve um pico e, em seguida, caiu vertiginosamente; houve gradativa queda do desemprego e aumento no salário real (Ibid.). Em 2008, devido à crise econômica mundial, a taxa de inflação voltou a crescer, no entanto, segundo Almeida et al. (2016), medidas anticíclicas de incentivo à atividade econômica foram capazes de evitar o aumento do desemprego [figura 13] - na história, Sandra vendeu as ações da Google um dia antes da explosão da crise, como indicado por Zero no passado, e investiu o dinheiro na compra da universidade e na criação de um fundo de tecnologia para financiar a pesquisa com o acelerador de partículas. Os dados ainda mostram que "alguns dos melhores índices do governo Lula vêm dos anos de 2009 e 2010: inflação e desemprego baixos são acompanhados por bons níveis de crescimento. O Brasil era apontado como o primeiro país a superar a crise mundial" (ALMEIDA et al., 2016, p. 6) - momento em que Zero atinge a felicidade ao se unir a Helena. 
Figura 13 - Gráfico inflação x desemprego no Brasil - 2002 a 2016
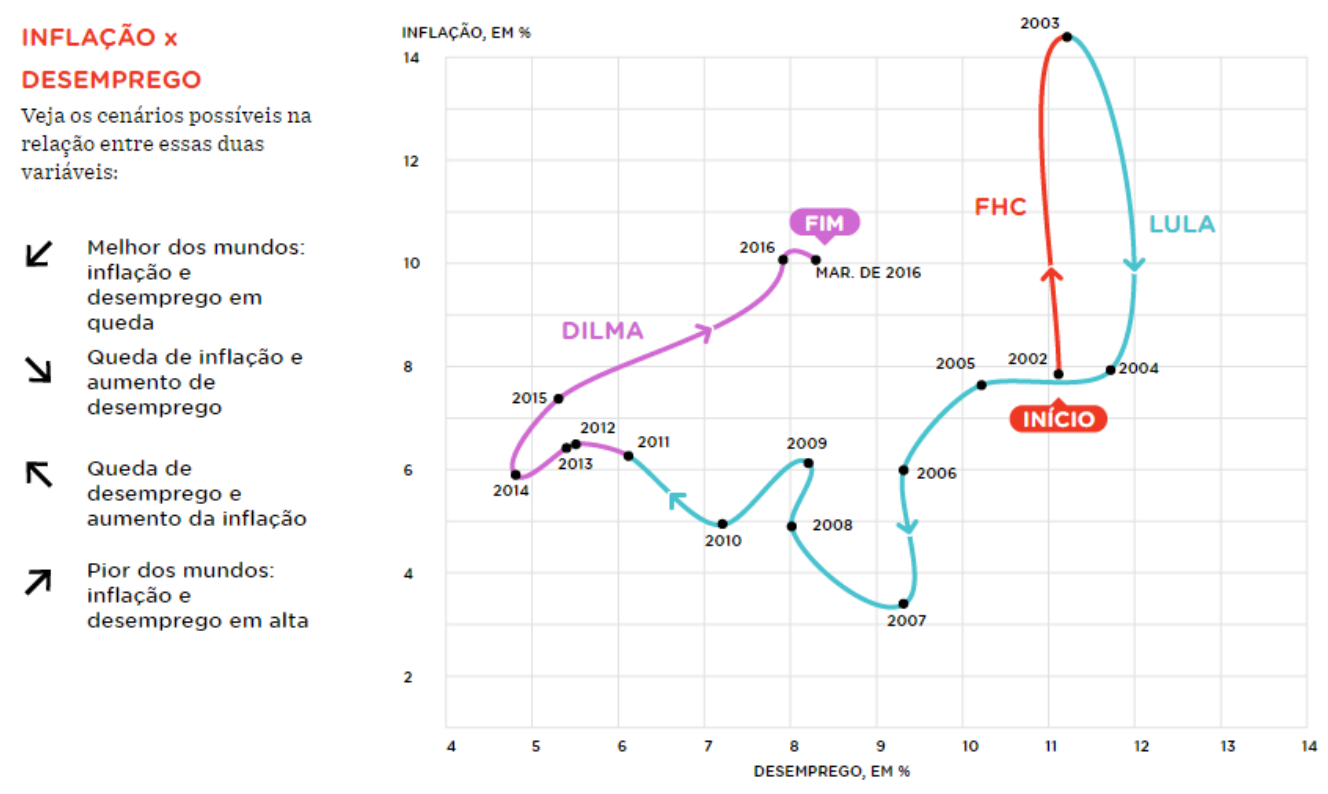

Fonte: Almeida et al. (2016)

Acreditamos que na associação entre a narrativa e as políticas econômicas do país, a mensagem central do filme, que preza pelo equilíbrio, se aproxima do ensaio desenvolvimentista que, com sua política de conciliação de classes, se propôs a conciliar políticas econômicas antagônicas (MORAIS, L.; SAAD-FILHO, A., 2011; SINGER; LOUREIRO, 2016). Nas palavras de Singer e Loureiro (2016, p. 12): “Ao mesmo tempo, na medida em que buscou avançar sem fazer transformações estruturais - seja no plano dos direitos, seja no plano da economia ou da ideologia -, a segunda experiência desenvolvimentista caracterizou-se pela extrema ambiguidade."

Assim como Kellner identificou na figura da personagem Rambo - protagonista do filme Rambo: programado para matar (KOTCHEFF, 1982) - ao compará-la com os EUA após a guerra do Vietnã ${ }^{32}$, para nós, Zero representa a pátria que foi humilhada e depois alcança a redenção; após séculos de fracasso nas tentativas em torna-se a nação do futuro, o Brasil concretiza o mito pela cultura da mídia. Kellner (2001, p. 94) explica como esse processo se dá:

[...] a parafernalha cinematográfica do espetáculo contribui para criar uma experiência de aquisição de poder. Assim como ocorre com os videogames, o espectador é convidado a alcançar uma posição de domínio [...]. 
[...] O espetáculo, portanto, investe o público de poder, propiciando-lhe um sentimento passageiro de domínio e força, o que compensa o declínio do poder na vida diária.

A partir do percurso gerativo de sentido fica claro que O Homem do Futuro é mais uma versão do arquétipo da ficção científica que se repete desde Frankenstein (SHELLEY, 1818): “[...] o do cientista louco que em sua árdua perseguição por conhecimento e poder trai valores humanos básicos" (EVANS, 2009, p. 13, tradução nossa ${ }^{33}$ ). Sobre a obra de Shelley, Evans (Ibid., p. 13) diz que essa, ao mover a fonte do terror do sobrenatural para o científico, exemplificou a rejeição romântica da crença cartesiana do século XVIII do cientista como herói e na tecnologia como inerentemente boa. No entanto, apesar valores similares, observamos que $\mathrm{O}$ Homem do Futuro nos traz um cientista complexo que não fica preso no dualismo ético entre o bem e o mal, mas transita entre ambos de acordo com suas vontades humanas, o que podemos interpretar como uma característica da pós-modernidade. Stuart Hall, ao citar Kobena Mercer, alega que "a identidade somente se torna uma questão quando está em crise, quando algo que se supõe como fixo, coerente e estável é deslocado pela experiência da dúvida e da incerteza" (MERCER ${ }^{34}, 1990$ apud HALL, 2014, p. 10); é o que ocorre com Zero, que ao passar por uma instabilidade (a viagem no tempo inicial) tem de conciliar aspectos de personalidades opostas de seus diferentes egos.

A tradição do controle da natureza também se faz presente no filme analisado. $\mathrm{Na}$ narrativa de Torres é o ser humano que tem o controle da ciência por meio da máquina do tempo, contudo, isso não significa um controle de seu próprio destino, pelo menos não por completo. Independente do caminho tomado por Zero/João, a predestinação desse em se tornar uma pessoa de destaque, seja no campo científico ou no mercado financeiro, está presente, o alcance do objetivo amoroso também é certo, já que esse fica com Helena em todos os tempos e realidades; sua permanência juntos é retratada como uma consequência às suas ações. Novamente um meio termo entre escolhas e destino, como se o ponto final já estivesse dado, mas como chegar a ele é de determinação das personagens.

Ao considerarmos Zero como a personificação do Brasil, o país também pode ser interpretado como predestinado em se tornar a nação do futuro. No contexto do filme isso pode ser encarado tanto em uma "realidade direta" como numa "realidade alternativa", não só

33 A transcrição da frase em sua língua original encontra-se já citada na nota de rodapé número 4. 34 MERCER, Kobena. Welcome to the Jungle. In: Rutherford, J. (Org.). Identity. Londres: Lawrence and Wishart, 1990. 
por ter se dado no Rio de Janeiro o desenvolvimento do conversor de partículas/máquina do tempo, com os projetos de Zero e de Sandra, e por sempre ser um brasileiro a pessoa certa para operá-lo e conduzir o país no caminho a um futuro próspero; mas também pela postura de superioridade de Zero em relação à sua substituição por Steve Webbs ${ }^{35}$, personagem que interpretamos como representação do imperialismo dos EUA, presente aqui para nos mostrar que, nesta ficção, o Brasil é a potência econômica que exerce o poder hegemônico, contudo, de forma mais humanizada: ao invés de ser uma nação que baseou seu desenvolvimento no capitalismo predatório, o país também preza pelo amor, algo próximo ao discurso do ensaio desenvolvimentista, que tentou equilibrar crescimento econômico em favor do capital financeiro e desenvolvimento social; uma utopia.

Mesmo com a articulação conjunta de todas as características estruturais e narrativas discorridas até aqui, apesar de não cair no fator fake devido à qualidade de sua produção, o filme não se torna uma autêntica ficção científica hard ao optar pela superficialidade de seu discurso científico. Em sua metodologia para analisar as narrativas de FC em relação ao seu conteúdo científico, Piassi e Pietrocola (2009) elaboraram categorias com base em critérios bem delimitados e que desempenham diferentes papéis, como "científico", "sobrenatural", "real”, "extraordinário", "inusitado", "possível”, “conceitual” e "conexo". Segundo o descrito pelos autores, identificamos que o discurso científico contido em $\mathrm{O}$ Homem do Futuro pode ser categorizado como "apelativo", por conter a presença de elementos científícos, extraordinários e conexos, porém com falta de elementos sobrenaturais, reais, possíveis, conceituais e que possuam explicação. Os autores explicam:

O vínculo que se estabelece com a ciência ocorre por relações vagas de contexto e não pela construção de uma ciência ficcional convincente. Há aqui, no entanto, um contrato implícito com o leitor de que esses artefatos e eventos têm uma explicação plausível, embora tal explicação seja tênue e permaneça na maior parte das vezes apenas no plano da expressão por meio das terminologias científicas. (PIASSI, L. P.; PIETROCOLA, M., 2009, p. 534)

Como espectadores/as, somos informados/as de que é o acelerador de partículas que faz com que Zero viaje no tempo, contudo, em momento algum nos é explicado o quê nele permite o deslocamento no tempo e no espaço e qual a explicação científica, mesmo que irreal, de Zero sempre ser transportado para o dia 22 de novembro. Até mesmo a própria

35 Indicamos aqui a similaridade entre o nome da personagem Steve Webbs e do empresário estadunidense do setor de informática, Steve Jobs, co-fundador, presidente e diretor executivo da Apple Inc., de 1976 até seu falecimento em 2011. 
máquina do tempo é tratada com certo descaso na narrativa, sendo por algumas vezes chamada de conversor de partículas, e por outras, de acelerador de partículas. Acreditamos que o acelerador de partículas (colisor de hádrons) foi escolhido como o objeto que representa a ciência pois, no contexto histórico em que o filme foi produzido, representavam no imaginário popular o ápice em desenvolvimento científico - e econômico, já que necessitam de investimentos bilionários - e constantemente apareciam em veículos midiáticos sensacionalistas, ao ser criada uma crença popular de que os testes que estavam sendo feitos com o Large Hadron Collider (LHC), maior acelerador de partículas do mundo, poderiam causar danos que chegariam ao fim da humanidade.

Por outro lado, o filme mobiliza com sucesso a imitação de uma estética e de características culturais de determinada época que, apesar de muito difundidas pela cultura da mídia dos EUA, não ocorreram no Brasil ${ }^{36}$. Não é comum às universidades brasileiras, públicas ou privadas, salas de aula similares às de grandes universidades dos Estados Unidos, nem festas à fantasia ou a figura do perdedor (loser) em nossos filmes. É notável na construção narrativa uma aproximação com a clássica trilogia da década de 1980, De Volta para o Futuro (ZAMECKIS, 1985).

Essa forma de imitação, o pastiche, é uma das principais características que Jameson (1996) identifica na arte pós-moderna, aspecto que representa inviabilidade de um estilo pessoal pelo/a autor/a (JAMESON, 1996, p. 43) e a impossibilidade na criação de novos estilos. Ele explica:

O pastiche, como a paródia, é o imitar de um estilo único, peculiar ou idiossincrático, é o colocar de uma máscara linguística, é falar em uma linguagem morta. Mas é uma prática neutralizada de tal imitação, sem nenhum dos motivos inconfessos da paródia, sem o riso e sem a convicção de que, ao lado dessa linguagem anormal que se empresta por um momento, ainda existe uma saudável normalidade linguística. (JAMESON, 1996, p. 44).

O autor identifica como causas de tal sintoma o colapso da ideologia do estilo do alto modernismo, o desaparecimento do sujeito individual, de forma com que aos/ às produtores/as culturais só resta a alternativa de se voltar ao passado (JAMESON, 1996). Ressaltamos que este é um quesito caro em nossos estudos e também será mobilizado na próxima análise como diferenciação entre as duas abordagens.

36 Algo que assimilamos à cultura da juventude oitentista dos EUA, muito popular no cinema da época voltado ao público jovem, como, por exemplo, Gatinhas e Gatões (HUGHES, 1984) e A Garota de Rosa Shocking (DEUTCH, 1986). 
O fato de a indústria audiovisual brasileira, por muito tempo taxada de precária ou até mesmo inexistente, mesmo com suas dificuldades e truques, produzir com maestria um gênero que nos é estrangeiro, característico de grandes estúdios e conhecido por sua demanda de estrutura tecnológica, sem cair no estranhamento, pode soar como uma aproximação ao futuro, algo que nos deixa mais próximos às grandes potências. Retomaremos a este elemento mais à frente pois será mobilizado de outra forma no próximo filme a ser analisado e servirá como fator de distinção entre os dois objetos.

Por fim, entendemos que a mensagem passada em $\mathrm{O}$ Homem do Futuro é de que a melhor escolha, nas telas ou fora delas, é sempre a que preza pelo equilíbrio, seja entre o trabalho e a vida pessoal, entre a ciência e os sentimentos, ou, até mesmo, entre os sistemas socioeconômicos.

\subsection{Branco Sai, Preto Fica}

Em Branco Sai, Preto Fica acompanhamos o desenvolvimento de três histórias paralelas, porém não desconexas: a de Marquim, homem negro e morador da Ceilândia, que tornou-se cadeirante após ser baleado pela polícia durante o fechamento do clube Quarentão, reduto da cultura negra na cidade em 1986, e que, cansado da subordinação imposta por Brasília aos habitantes da periferia do Distrito Federal, planeja vingança; Sartana (também conhecido por Shokito), antigo amigo de Marquim, que teve uma de suas pernas amputadas ao ser pisoteado pela cavalaria durante o ataque policial ao clube; e Dimas Cravalanças, agente terceirizado que veio do futuro em busca de provas para incriminar o Estado brasileiro por crimes contra minorias.

Como forma de manter vivas suas memórias, Marquim mantém uma rádio clandestina em uma espécie de bunker/ laboratório no subsolo de sua casa, onde passa grande parte de seu tempo relembrando sua juventude e indagando sobre onde estaria seu amigo. Lá, ele também trabalha na construção de um grande artefato emissor de luz, que ao longo do filme descobrimos se tratar de uma bomba com conteúdos sonoros da cultura da Ceilândia, cujo objetivo é explodir no Plano Piloto. Com a ajuda do DJ Jamaika - a quem dará em troca do trabalho passaportes falsificados de acesso a Brasília -, ele grava artistas e sonoridades locais, elementos do povo periférico rechaçados pelas classes mais altas, para compor o conteúdo de sua arma. 
Diferente de Marquim, cuja ação se dá quase que totalmente no espaço doméstico, Dimas Cravalanças perambula pela cidade em busca das provas de que tanto almeja, concentradas na figura de Sartana. Concomitantemente, ele tenta se comunicar com a base de sua operação no futuro, mas é impedido pela precarização dos serviços públicos em ambas as épocas, e enfrenta a dúvida de retornar ou não à uma realidade na qual não tem esperança.

Já Sartana passa seus dias quietos e solitários tirando fotos da cidade, fazendo desenhos premonitórios do viajante do tempo e da explosão, e em busca de próteses para consertar ou realizando o conserto das próteses de outras pessoas. Uma das poucas cenas da trama em que a personagem quebra esse padrão é quando, pouco antes de preparar a explosão, busca por um serviço clandestino para desvincular sua perna mecânica do sistema a que estava atrelada e poder, de fato, ser seu dono.

$\mathrm{Na}$ reta final da narrativa, sem ser mostrado ou explicado ao/à espectador/a como, Sartana e Marquim se reencontram e acertam os últimos detalhes da explosão da bomba. Logo após, Sartana rouba energia do sistema do metrô da cidade para concretizar a operação, enquanto seu amigo esconde e queima materiais que poderiam incriminá-lo.

Após conseguir as provas que veio buscar e lutar contra inimigos invisíveis da sociedade, Dimas opta por não impedir a explosão da bomba, mesmo sabendo que uma das consequências disso será ficar preso no passado.

\subsubsection{Análise de Branco Sai, Preto Fica}

Para darmos início a uma análise do filme em questão, precisamos ter consciência de onde e para quem o autor fala. Apesar de graduado em cinema pela Universidade de Brasília, Adirley Queirós não é fruto da classe média ou da elite, tendo sido criado na Ceilândia, periferia da capital federal, onde vive até o presente, assim como o elenco e parte da equipe técnica de Branco Sai, Preto Fica. Dessa forma, ao mostrar os problemas da cidade satélite cujo nome deriva de Campanha de Erradicação de Invasões (CEI $)^{37}$ - programa higienista público ocorrido entre 1969 e 1971, que transferiu a população pobre para uma região sem infraestrutura a cerca de 30 quilômetros do Plano Piloto -, ele mostra problemas que fazem parte de seu cotidiano, ajudaram a construir sua identidade e moldaram seu trabalho.

Em entrevista ao Canal E (2014), o diretor informa que ao usar a premissa de um 
massacre policial ocorrido em 1986 no clube Quarentão, parte de uma memória coletiva construída, de uma ficção que tornou-se mais importante do que o fato em si; um mito, de certa forma:

\begin{abstract}
Esse baile do Quarentão, nos anos 80, era meio que a grande identidade da cidade, $[\ldots]$ a nossa geração circulava muito ali [...]. Ela ia pra sala de cinema ver filmes, geralmente filmes de caratê, e de lá a gente ia pro Quarentão. Aquele espaço ali acho que foi o primeiro momento de uma formação de identidade da Ceilândia. [...] Esse baile foi constantemente sendo criminalizado pela polícia, porque, obviamente, ele representava um local de identidade e ele, obviamente, era um lugar frequentado mais por pessoas de periferia. [...] Essa criminalização levou [...] a ter batidas policiais constantes [...] e chegou certo dia que eles chegaram a fechar o baile. Esse fechamento do baile virou uma espécie de lenda na cidade, todo mundo estava no dia em que fechou o baile. Toda uma geração começou a internalizar que estava naquele dia lá; inclusive eu nem sei se estava ou não [...]. (QUEIRÓS, 2014)
\end{abstract}

Há uma afetividade que não pode ser posta de lado. Com essa consideração, não enxergarmos a síntese entre documentário e ficção (circuit bending) em Branco Sai, Preto Fica como algo meramente estético; Queirós não quer apenas contar uma história, quer mudar a versão oficial da narrativa. Esse movimento nega uma cosmética da fome ${ }^{38}$ típica de filmes da cultura da mídia que retratam a periferia brasileira.

Similar ao que Lúcia Nagib (2006, p. 162) encontrou ao analisar O Invasor (BRANT, 2002), em Branco Sai, Preto Fica, a articulação de três elementos essenciais contribuem para produzir não apenas um efeito ilusionista característico ao cinema, mas também uma impressão de revelação da realidade de um país, são eles:

a) Alegorias à cena política real (o racismo institucional), acrescidas de elaborações fictícias (o massacre no clube Quarentão em 1986);

b) A fantasia pura contida na possibilidade de explodir o Plano Piloto e na viagem no tempo de Dimas;

c) Diagnóstico social.

Sobre o filme de Brant, Nagib (Ibid.) ainda observa: "O fato de a predominância do material fictício não prejudicar o efeito documental sugere que este deriva não da história, mas do modo como ela é narrada", o que acreditamos também se encaixar neste caso.

Além da bomba sonora e da viagem no tempo, o novum do filme também se encontra

38 Termo cunhado por Ivana Bentes em oposição à "estética da fome", de Glauber Rocha, para designar uma estética típica do cinema da retomada em que a periferia é mostrada com uma beleza publicitária que evidencia a distância do narrador àquela realidade. Cf Bentes, 2001. 
em detalhes que, apesar de não existirem no presente, mantém diálogo com a atualidade. Não é totalmente inconcebível a questão de existir polícia do bem-estar social ou se será preciso um passaporte especial para circular por Brasília, mas a partir de quando isso será necessário?

Assim como Suppia e Gomes (2015), notamos que o circuit bending também é explorado na composição do quadro cinematográfico (misé-en-scène) e na cenografia com a escolha de locações reais - apresentadas principalmente nas andanças de Dimas Cravalanças por espaços abertos da cidade - e provoca estranhamento cognitivo ${ }^{39}$ em paisagens comuns; ao termos uma minoria social como ente narrador, os espaços passam a ser vistos como zonas de guerra, territórios que, segundo Mesquita (2015, p. 10), se aproximam do pós-apocalíptico.

No entanto, a precariedade dos recursos de produção que vemos em Branco Sai, Preto Fica, mesmo em uma ficção científica, não recai no fator fake, não só por este filme não ser um representante do gênero em sua totalidade, já que o une ao documentário, mas também por alterar, segundo Carrera (2018), as convenções do documentário tradicional, explorando novas possibilidades de concepção de realismo e de senso de futurismo; no entanto, o principal é que por mais que exista uma estética da indústria típica de filmes de ficção científica, neste caso, não há um outro a ser copiado; não estamos falando de um cinema que almeja um lugar no centro, pelo contrário, sente-se confortável em sua posição periférica e quer legitimá-la.

É preciso ressaltar que tal estética não é apenas derivada da linguagem adotada, existe uma real preocupação artística de Queirós sobre o retrato plástico de suas questões:

[...] é engraçado porque eles [a indústria cinematográfica] querem associar a gente, embora Ceilândia, periferia ou fora do centro, somente a questões do conteúdo, e é engraçado quando a gente lida com a questão estética informal, parece que isso é desconsiderado [...]. Parece que a gente não teria capacidade de pensar uma formalidade no cinema. Porque o cinema é conteúdo, mas ele só tem potência se for pra estética. [...] não adianta ter um conteúdo, o conteúdo, para ter uma potência de cinema, tem que ter um trabalho estético ali $[\ldots]$ para que o conteúdo avance. (QUEIRÓS, 2014).

Assim como Kellner (2001) identificou em Faça a Coisa Certa (LEE, 1989), Branco Sai, Preto Fica apresenta características modernistas não só por sua escolha de preservação das marcas estilísticas de seu criador, recusando o pastiche, mas também no sentido do que

39 Segundo Suvin (1979), o estranhamento cognitivo é causado por uma quebra de continuidade nas leis, naturais ou não, entre os mundos do/a autor/a e a ficção. O estranhamento diferencia a FC do gênero realista, já a cognição a diferencia do mito, da lenda e da fantasia. Cf. SUVIN, 1979, p. 7-8. 
Peter Bürguer (2008) identifica como "vanguarda histórica"40 por sua tentativa de transformação social. Contudo, adquire traços pós-modernos ao unir uma narrativa convencional, que apresenta argumento e personagens formais, ao documentário.

Mesmo com união de gêneros e forma não convencional, o filme apresenta algumas características clássicas da ficção científica cyberpunk, como a rebelião de uma cultura marginalizada contra estruturas e autoridades e crítica do presente sob a ótica de um futuro não tão distante - ou presente alternativo - em que mega conglomerados (neste caso, o Estado desenvolvimentista) controlam a vida da população. Segundo Kellner (2001, p. 385):

A ficção cyberpunk é uma resposta a essa situação; tenta desenhar um mapa das realidades tecnológicas, econômicas, sociais, políticas e culturais da atualidade, captando a intensidade e o dinamismo das momentosas mudanças, bem como as novas possibilidades e as novas ameaças para os seres humanos [...]. Assim, teoria e cultura pós-modernas e ficção cyberpunk são produtos do mesmo ambiente high-tech, servindo ao mesmo tempo, para mapeá-lo e elucidá-lo.

De acordo com Causo (1996), o cyberpunk brasileiro não costuma figurar com exatamente as mesmas características de sua versão original anglófona e apresenta diferenças às quais foram dadas o nome de tupinipunk. Enquanto escritores/as de língua anglo-saxã enfatizam a realidade virtual, no Brasil o foco está no submundo urbano das grandes cidades e em conspirações, nacionais ou não, com ênfase na violência física, na sexualidade, no nacionalismo político e em injustiças sociais representadas de diversas formas; além da forte utilização do corpo como símbolo de resistência cultural (GINWAY, 2005a). Para nós, o filme em questão apresenta traços clássicos do movimento cyberpunk tradicional e alguns resquícios do tupinipunk ressignificados, como a união da violência física à institucional (o conflito no Quarentão e outros ataques indiretos do Estado, como a precariedade em serviços públicos) e a disputa não só do espaço geográfico, mas também da memória e da narrativa oficial.

Posto isso, ao aplicarmos a semiótica de Greimas e identificarmos Marquim como sujeito e a explosão da bomba sonora em Brasília como o objetivo de seu programa narrativo, somos obrigados a ir mais afundo e reconhecer alegorias. Bombas são artefatos de guerra usados para a destruição, o que nos leva a questionar o porquê de Marquim ter como objetivo

40 Para Bürguer há “[...] uma relação indissociável de tensão entre duas tradições da modernidade, que antes se definiam convencionalmente uma contra a outra: a estética da autonomia, cujo auge foi alcançado com o esteticismo do final do século XIX, e o impulso vanguardista de superação da autonomia e recondução da arte para a prática da vida" $(2008$, p. 11). 
a destruição de uma cidade que ele não habita e que sequer é citada diretamente no filme, aparecendo na tela somente por meio de desenhos de seu arrasamento ao final. O que ela representa?

A ambiciosa construção de Brasília no século passado foi a materialização do projeto desenvolvimentista aplicado ao país, logo, pode-se dizer que seu propósito era apagar o passado para construir uma nova perspectiva de futuro, um futuro desenvolvido e tecnológico. Contudo, a expectativa de uma cidade na qual o espaço seria utilizado racionalmente em virtude de um caráter mais social e uma convivência harmônica entre ricos e pobres não saiu como o planejado quando posto em prática (GOMES, 2014, p. 5). A quantidade de candangos - migrantes, em sua maioria nordestinos, que rumaram ao Planalto Central em busca de empregos na construção civil - foi maior do que pôde prever o projeto de Lucio Costa e Oscar Niemeyer. A partir da etnografia de Holston (1993), Mesquita (2017, p. 4) nos diz que, neste caso, na tentativa de exterminar a pobreza que a construção da cidade não eliminou por si só, o Estado foi promotor da expansão da periferia e da desigualdade ao tentar escondê-la. Como espelho do futuro do país, Brasília se tornou o reflexo do fracasso, e os filmes de Queirós fazem questão de contar essa história sob um ponto de vista muitas vezes negligenciado, como já havia sido feito em A Cidade é uma Só?, de 2011.

Em Branco Sai, Preto Fica, o apagamento da periferia é trazido quase que de forma literal com o mote do massacre da juventude preta e pobre pela polícia no baile do Quarentão, apenas um episódio dentre tantos que ocorreram e ocorrem fora da ficção. Acreditamos que isso contribui para enxergarmos a cidade de Brasília, e os poderes institucionais que essa representa, como antissujeito da narrativa, enquanto a Ceilândia, figurativizada em Marquim, faz o papel de sujeito cujo programa narrativo é se vingar por meio da explosão de uma bomba com a cultura musical de sua cidade, acabando com a relação de poder imposta. A partir de tal ponto de vista, elaboramos o seguinte quadrado semiótico [figura 14]: 
Figura 14 - Percurso narrativo de Marquim

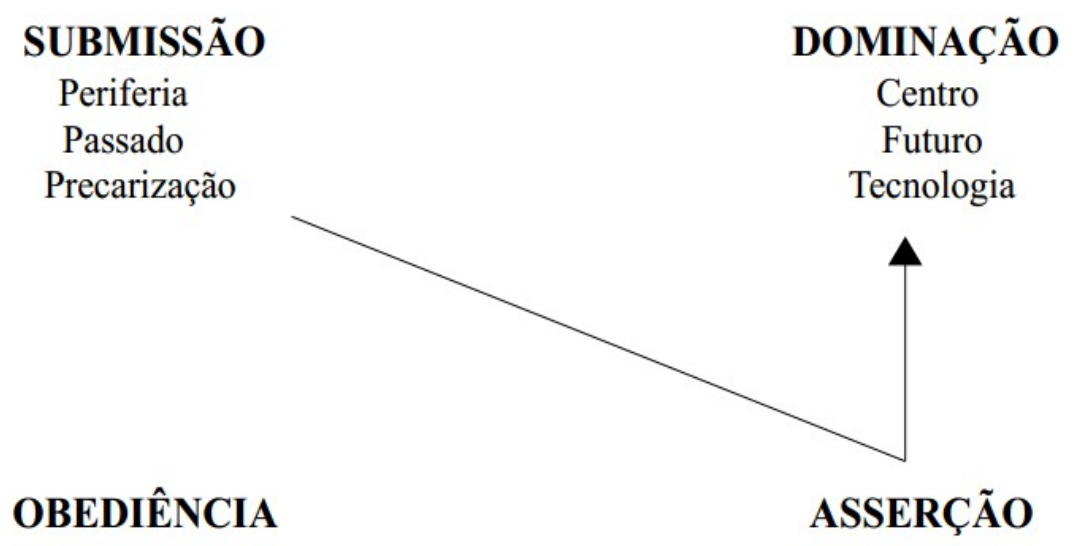

Fonte: Maria Estela Silva Andrade, 2019.

No início do percurso traçado, Ceilândia se encontra submissa a Brasília, estado que se prolonga desde sua criação em 1971 e exemplificado visualmente na tela pela precarização de todos os espaços que fazem referência ao sujeito. Logo no primeiro quadro, assumimos o ponto de vista de Marquim, que vê um conjunto de casas com estruturas oxidadas, pinturas com cores descontinuadas e descascadas, pichações nos muros, roupas estendidas nas varandas e carros velhos em frente a algumas das garagens; o retrato de um bairro periférico. No corte seguinte, sob outro ponto de vista, o acompanhamos descer por meio de uma engenhoca a um porão, local com fiação exposta e roldanas por todo o teto, azulejos de modelos desiguais, paredes sujas e com infiltrações; a luz branca nos remete a uma espécie de laboratório [figura 15]. Já na casa de Sartana, localizada às margens de uma avenida movimentada e próxima aos trilhos externos do metrô, encontramos características similares de improvisação de materiais e de espaço, que também nos remetem a um laboratório devido à quantidade de próteses de partes do corpo humano com as quais ele trabalha, quase como um Dr. Frankenstein. 
Figura 15 - Frame do filme Branco Sai, Preto Fica. Marquim em seu bunker.

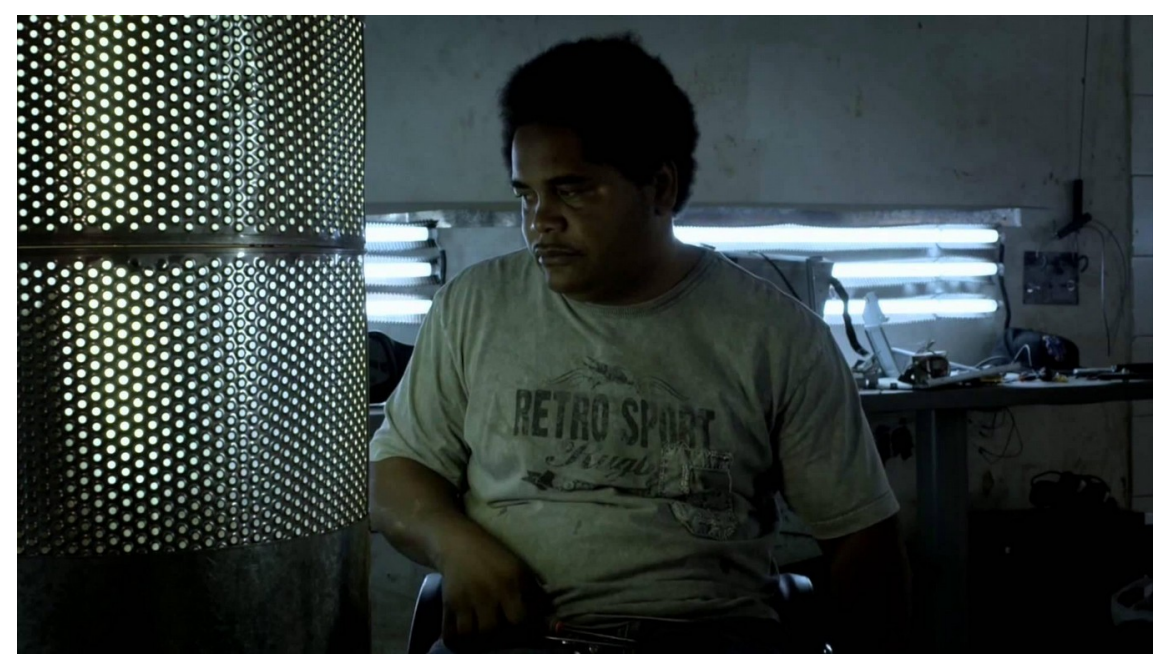

Fonte: QUEIRÓS, 2014.

Figura 16 - Frame do filme Branco Sai, Preto Fica, Sartana na varanda de sua casa.

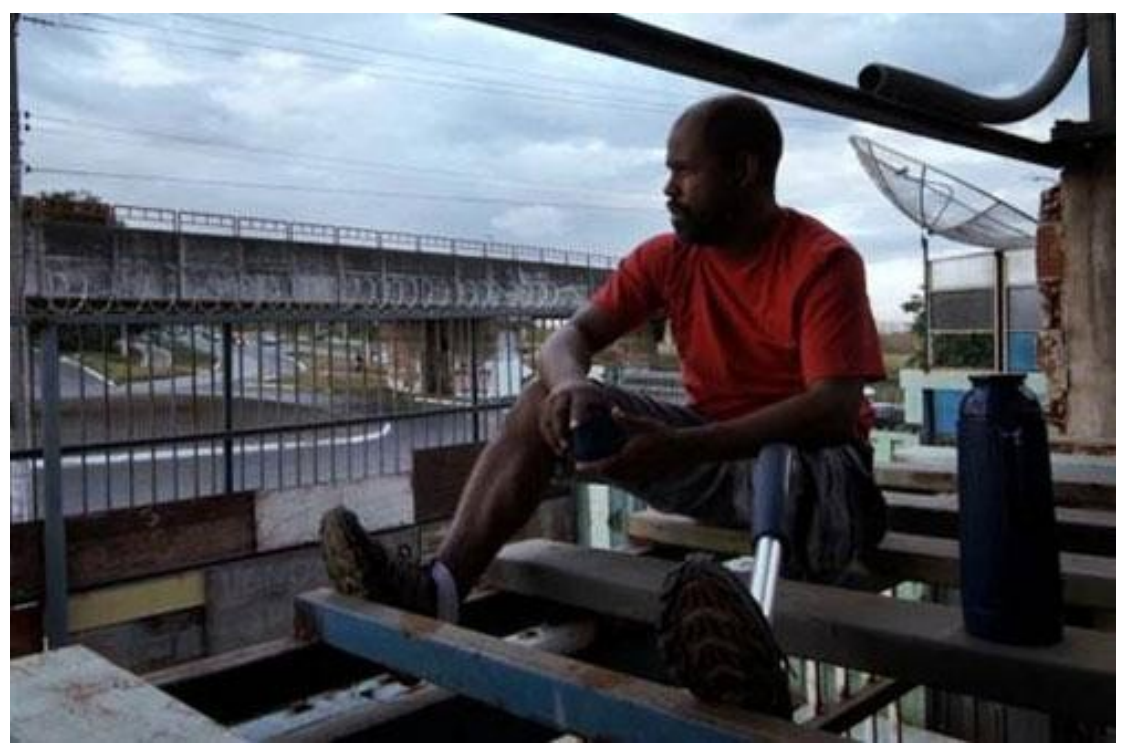

Fonte: QUEIRÓS, 2014

A presença de grades e câmeras de vigilância nas casas somadas ao toque de recolher da polícia do bem-estar social contribuem para uma impressão de insegurança na cidade, no 
entanto, a construção narrativa nos faz questionar qual seria a ameaça se não o próprio sistema que, supostamente, deveria ser o protetor. A violência institucional se faz presente também por outras formas para além dos ataques físicos ocorridos no Quarentão: a necessidade de um passaporte para transitar por Brasília, as dificuldades de Marquim em acessar a saúde pública e o rastreamento de Sartana por meio de sua prótese, exemplos de como o projeto recente de modernização proporcionou, por um lado, certa ascensão social que permitiu a Marquim, inclusive, ter um carro da marca BMW -, mas, por outro, manteve a ausência de direitos básicos.

A essas situações, a presença de Cravalanças não indica melhora futura: em 2070 ele é um agente terceirizado (parte do precariado no entendimento do público de 2014), o Estado, que ainda não assumiu responsabilidade pelos crimes praticados no passado contra minorias sociais, continua ineficiente, como demonstram as condições da nave e as perdas de sinal que impedem Dimas de se comunicar com seu tempo de origem - ambas justificadas pela contenção de gastos -; além de tudo, a situação não tende a melhorar com a chegada da vanguarda cristã ao poder. Diante tal cenário, o agente se questiona: "Voltar pra quê? O que vou fazer nesse futuro?", e opta por não impedir a grande explosão.

Uma cena bastante significativa à nossa análise é a da batalha de Cravalanças no ferro velho contra inimigos invisíveis [figura 17]. O filme lida com um objetivo concreto - a explosão de uma bomba, a destruição - contudo, os reais inimigos, representados pelo desenvolvimentismo, o racismo, o consumismo, a "falta de fazer as coisas", não são palpáveis. Estes valores se encontram tão intrínsecos na sociedade que ao final da cena, quando Dimas quebra a quarta parede e aponta a arma invisível em direção ao/à espectador/a, os/as delega responsabilidades e os/as denuncia como cúmplices; por sua não rebelião, o público passa a ser o/a "paga pau do progresso", o/a "racista que não vai mudar a cara nunca" e o/a "boca aberta" denunciados pelo agente. 
Figura 17 - Frame do filme Branco Sai, Preto Fica, Dimas ao quebrar a quarta parede

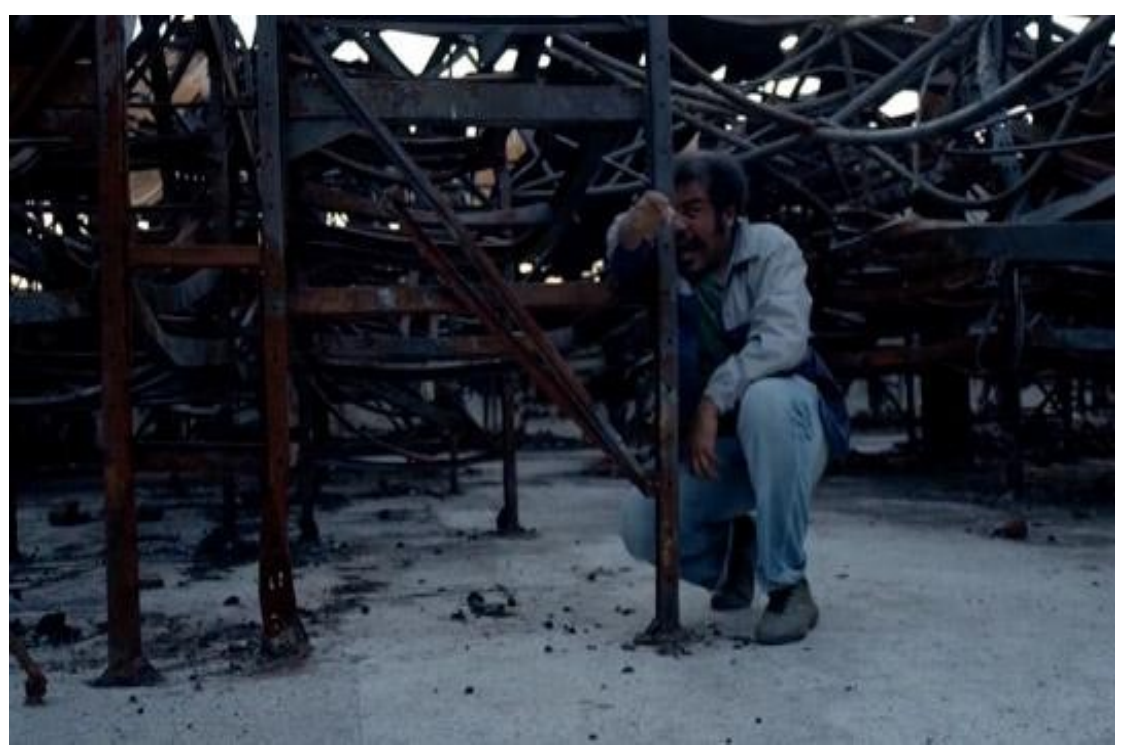

Fonte: QUEIRÓS, 2014.

Independente da metodologia adotada, acreditamos que qualquer (tentativa de) análise de Branco Sai, Preto Fica que não leve em conta a questão racial se torna incompleta, não apenas pela explicitude de seu título, mas porque isso seria ignorar não só questões narrativas, como também a posição militante da obra e a forma com que essa dialoga com a sociedade.

O filme em questão usa o exemplo do projeto desenvolvimentista da construção de Brasília e sua relação com a Ceilândia para exemplificar a relação entre raça e classe no contexto brasileiro. Com a população branca em posições de poder e a população negra sob escravidão por cerca de 300 anos desde o início da colonização, foi sedimentada no Brasil uma sociedade que vê com naturalidade a divisão racial, sendo que o afastamento às periferias sempre cabe, em sua maioria, aos de coloração retinta; dados divulgados pelo Instituto Brasileiro de Geografia e Estatística (IBGE) em 2013 indicam que entre a camada mais pobre da população, o índice de negros e negras é quase 3 vezes maior do que o de pessoas brancas, enquanto que a faixa mais rica contava com $81,6 \%$ de brancos contra $16,2 \%$ de pretos e pardos.

Porém, a situação não é tão simplista quanto pode parecer. A pós-modernidade trouxe 
novas formas de concepção das identidades, o indivíduo moderno, antes visto como sujeito unificado, agora é fragmentado (HALL, 2001), o que implica em uma pluralidade de centros de poder, situação que Laclau identificou como "deslocamento" (1990 ${ }^{41}$ apud HALL, 2001, p. 14). A concepção de Stuart Hall sobre esse conceito nos ajuda a entender a distribuição dos centros de poder não só na sociedade contemporânea mas também na narrativa:

\begin{abstract}
As sociedades da modernidade tardia [...] são caracterizadas pela "diferença", elas são atravessadas por diferentes divisões e antagonismos sociais que produzem uma variedade de diferentes "posições do sujeito" - isto é, identidades - para os indivíduos. Se tais sociedades não se desintegram totalmente não é porque elas são unificadas, mas porque seus diferentes elementos e identidades podem, sob certas circunstâncias, ser conjuntamente articulados. Mas essa articulação é sempre parcial: a estrutura da identidade permanece abstrata. (HALL, 2001, p. 14)
\end{abstract}

A partir dessa visão, Hall faz o seguinte comentário a respeito da dinâmica existente entre raça e classe nas sociedades da modernidade tardia:

\footnotetext{
As pessoas não identificam mais seus interesses sociais exclusivamente em termos de classe; a classe não pode servir como um dispositivo discursivo ou uma categoria mobilizadora através da qual todos os variados interesses e todas as variadas identidades das pessoas possam ser reconciliadas e representadas. (Ibid., p. 15).
}

Ser uma pessoa pobre negra e uma pessoa pobre branca na Ceilândia, ou em qualquer lugar do Brasil, implica em diferentes processos de construção de identidades, de percepção do mundo e de inserção na sociedade. O branco sai e o preto fica para a chacina. Acreditamos ser devido a isso que tenha se dado a escolha por um elenco composto em sua totalidade por pretos e pardos. Aqui, Queirós, que não é negro, se diferencia de cineastas tradicionais modernos, no sentido atribuído por Jameson -, ao não querer falar pela negritude a partir de seu lugar de privilégio, mas o cede a essa para que possa gritar com sua própria voz.

Também acreditamos que para uma cultura da mídia que celebra padrões de beleza europeus, um elenco formado por características opostas, num contexto de celebração dessas e não de crise identitária, é uma afronta.

Novamente inspirados pela análise de Kellner a respeito de Faça a Coisa Certa (LEE, 1989), acreditamos que a obra da Ceilândia também pode ser interpretada como "um esvaziamento pós-moderno das opções políticas viáveis para os negros na época atual" (KELLNER, 2001, p. 208). Diante à pobreza, constante precarização, racismo e ausência de 
opções políticas tradicionais eficazes, a única saída é o combate - visão confirmada pela presença da música Bomba Explode na Cabeça ${ }^{42}$, de Mc Dodô, ao longo da sequência final de ilustrações da explosão do Plano Piloto. Fazemos nossas as palavras de Kellner (Ibid., p. 209) ao concluirmos que: "Segundo essa leitura pós-moderna, o filme projeta uma visão desolada e niilista do futuro, marcada pela desesperança e pelo colapso da moderna política de defesa do negro". Aqui, deixamos claro que, apesar de importantes conquistas dos movimentos de negritude durante os governos petistas, em especial o de Lula, acreditamos que a política de conciliação de classes do ensaio desenvolvimentista agiu como fator limitante à luta por equiparação racial uma vez que tentou agregar demandas de classes sociais opostas,

Em sua pesquisa, Ginway (2005a, p. 95) identificou que nas distopias brasileiras há uma

[...] tendência de protestar contra a política governamental de modernização, tanto quanto contra a de repressão. Ao fazê-lo, elas sucumbem ao que Robert Scholes e Eric Rabkin chamam de um 'impulso atávico para retornar ao que é percebido como uma época melhor em um sentido coletivo de história, ou em um senso individual de infância'. Esta saudade explica o impulso por trás da nostalgia pelo passado na ficção distópica brasileira como símbolos de oposição às políticas de modernização da ditadura.

Ao ser destruída a compensação subjetiva, o Quarentão, as personagens passaram a encarar a realidade em sua forma mais bruta. Já nos anos 2000, a abordagem histórica ficcional passou a admitir que a vocação utópica da situação fosse a criação de um novo marco zero a partir da simples explosão do inimigo, e assim foi feito. Assim como Nagib identificou em suas análises dos filmes Central do Brasil, (SALLES, 1998), O Primeiro Dia (SALLES; THOMAS, 1999) e Latitude Zero (VENTURI, 2000), o "zero", representando um novo começo - ainda mais se localizado na região central do país e no início de um novo século - "funciona ao mesmo tempo como anúncio e negação da utopia" (NAGIB, 2006, p. 61). Em Branco Sai, Preto Fica a utopia está contida na ironia de apagar o ícone do apagamento; a utopia de Brasília é negada para a construção de uma nova.

Por fim, em nossa visão, o filme se empenha em mostrar as falácias por trás dos mitos da democracia racial, do povo feliz e da grandeza nacional, que viraram realidade para uma parcela mínima da população. Branco Sai, Preto Fica não se trata de uma distopia, mas de uma utopia, no sentido desenvolvido por Jameson, pois mostra que a única forma de melhorar a realidade é por meio da destruição do sistema opressivo. Agora, o branco sai, o preto fica.

42 "Bomba explode na cabeça estraçalha ladrão/ Fritou logo o neurônio que apazigua a razão/ Eu vou comprar e com certeza a guerra eu vou ganhar/ Os trutas e as correrias vão me ajudar” (MC DODÔ, 2007). 


\section{CONSIDERAÇÕES FINAIS}

Após a teoria exposta e sua aplicação no corpus selecionado, nos foi permitido enxergar pontos de associação e de dissociação entre os filmes, que explicitaram características de uma geração a qual tende a reconhecer contradições do mundo (pós) moderno, assim como identificado por Ginway em sua pesquisa e nas palavras a mesma, “[...] jogando com conceitos de tecnologia, pós-modernismo, e a proliferação de significados, oferecendo uma nova identidade cultural para o Brasil em uma nova era cibernética" (GINWAY, 2005a, p. 146).

Em seus oito primeiros anos, a gestão petista conseguiu, a partir do ensaio desenvolvimentista, resultados expressivos à melhora de índices sociais e econômicos, que permitiram o ressurgimento do mito da nação do futuro; a aposta no sucesso brasileiro por parte do mercado econômico era tanta que a arrogância passou a ser o maior risco do país ${ }^{43}$. A partir de nossa análise, acreditamos que o filme $\mathrm{O}$ Homem do Futuro transparece e é favorável ao retorno do sentimento de grande nação quando opta por apresentar o Brasil como o único país do mundo com um acelerador de partículas, financiado por um fundo de investimentos privado e em posse de uma universidade particular, num contexto histórico em que os aceleradores de partículas representavam o suprassumo da ciência e políticas de acesso ao ensino superior, principalmente as que beneficiavam instituições privadas, cresciam e se mostravam bem sucedidas. Ademais, no centro do filme está um homem advindo do subúrbio e ex-bolsista, que supera adversidades e atinge seu objetivo de felicidade.

Como as obras da cultura da mídia sempre tentam atingir o maior público possível (KELLNER, 2001), não desconsideramos o fato de na conjuntura de produção do filme, os níveis de aprovação do governo do então presidente Lula atingiam níveis recordes e mantinham a expectativa com o governo iniciante de sua sucessora, Dilma Rousseff ${ }^{44}$. Além de tudo, a Rede Globo de Televisão, naquele momento, não possuía alta popularidade entre setores progressistas devido ao seu apoio à ditadura militar ${ }^{45}$ e por suposto apoio a candidatos opostos ao Partido dos Trabalhadores em eleições anteriores ${ }^{46}$, logo, usa de estratégias narrativas para cativar esse público.

43 No editorial Brazil Takes off, da revista The Econimist (2009), consta o subtítulo: "Now the risk for Latin America's big sucess is hubris".

44 Cf. MARTINS, Raphael.

45 Cf. ARBEX JR., 2015.

46 Cf. REDE GLOBO, [20--]. 
Também não deixamos de lado que o roteirista, produtor e diretor de $\mathrm{O}$ Homem do Futuro, Cláudio Torres, integra uma elite econômica e artística brasileira, o que o faz perceber e sentir as consequências de políticas adotadas pelo Estado de forma diferente do diretor Adirley Queirós, morador da Ceilândia e ex-funcionário público de baixo escalão. Apesar do caráter reformista do governo, a política de conciliação de classes adotada no período estudado, mesmo com fortes programas de transferência de renda, também estimulou fortemente os lucros do capital privado, o que resultou, segundo Singer e Loureiro (2016), numa integração e ascensão econômica que não necessariamente significaram cidadania, face do ensaio desenvolvimentista criticada em Branco Sai, Preto Fica, com a representação de que o futuro que chegou à periferia do Distrito Federal não é o mesmo do Plano Piloto, e essa ainda vive com resquícios do passado escravagista do Brasil.

Acreditamos que o viés socioeconômico também influencia na forma como os dois cineastas abordam a representação da tecnologia nas telas, de forma que colocam em evidência discrepâncias entre as duas pontas do sistema capitalista, em que uma é retratada pela defesa de políticas públicas e privadas para o progresso ao alcance de poucos (O Homem do Futuro), e a outra denuncia a precarização dos serviços públicos, tecnológicos e humanos, disponibilizados à população com menor renda (Branco Sai, Preto Fica). Apesar de o cyberpunk apresentar uma perspectiva pessimista quanto à tecnologia, e a ficção científica apelativa, mais extraordinária, cremos que as divisões dentro do gênero não foram tão determinantes quanto a divisão de classes sociais e formas de produção que contribuíram em favor de um discurso maior.

Ginway (2005a) constatou que nas obras brasileiras de FC publicadas entre 1974 e 1981, a questão racial, por ser mais restrita, era abafada pelo mito mais amplo da brasilidade, visto como símbolo de legítima identidade e de resistência contra o regime (GINWAY, 2005a, p. 95). Nesse sentido, acreditamos que, apesar de favorável ao regime, O Homem do Futuro mantêm essa característica por deixar completamente de lado qualquer questão a respeito de raça, apresentar total falta de representatividade racial e focar numa representação de país na qual o sucesso é certo para pessoas brancas e de classe média/ alta, mesmo num cenário de recentes conquistas da população negra com políticas de ações afirmativas. Não há necessidade narrativa para a completa ausência da negritude no núcleo principal e também fora dele. Mesmo que não intencional, essa escolha é representativa de um sintoma. Por outro lado, Branco Sai, Preto Fica assume uma postura oposta e não concebe o país do futuro sem 
equiparação racial, apesar de não contar com personagens brancas.

Se com um olhar muito superficial a questão sobre representatividade racial pode parecer semelhante, sob diferentes pontos de vista, em ambos filmes; ao aprofundarmos, vemos que não podemos correr o risco de cair em argumentos simplistas. Com nossos estudos sobre a cultura da mídia, acreditamos que a opção por um elenco totalmente branco em $\mathrm{O}$ Homem do Futuro se dá pela necessidade de atingir o maior público possível e não transcender linhas ideológicas. Já o filme da Ceilândia não possui essa obrigação e têm o objetivo contrário de afirmar uma posição e denunciar.

No entanto, as obras não apresentam apenas diferenças entre si, a representação feminina nas telas pareceu não ser uma preocupação de ambos cineastas. Diferente da raça, as questões de gênero na narrativa da Ceilândia são apagadas. As únicas mulheres presentes ao longo do filme são as cantoras de apoio que acompanham o cantor de forró, que por si só pode ser considerado como figurante, e a comandante do futuro que tenta contato com Dimas e dispõe de uma participação mínima. Da mesma forma que a classe não serve mais como categoria mobilizadora ou dispositivo discursivo de todos os interesses e identidades em que as pessoas possam ser representadas e reconciliadas (HALL, 2001), raça e gênero também não podem, sendo necessário adotar pontos de vista interseccionais. Ainda que consideremos o machismo comum no universo do cyberpunk, essa não é uma tendência que aparece com frequência no tupinipunk. Já a narrativa de Torres, apesar de contar com duas personagens femininas ativas, reproduz a estrutura clássica de Hollywood, em que mulheres são fetiches ao olhar masculino ${ }^{47}$. Helena, em termos semióticos, é objeto - valor de Zero equiparado ao dinheiro, enquanto Sandra, que ao primeiro olhar parece uma figura de poder, só está nessa posição por seguir instruções dadas pela personagem principal masculina em uma de suas intervenções no passado com o objetivo de satisfazer desejos futuros de Zero, e, quando jovem, é retratada como tola e ingênua.

Outra semelhança entre as narrativas está em como ambas abordam a humanidade. Diferente de muitos exemplos da FC atual que exploram o ser humano pelo viés de sua reificação, de sua substituição pela tecnologia ou até mesmo por outras formas de vida (KELLNER, 2001), assim como Kellner enxerga em Neuromancer (GIBSON, 2016), nos filmes abordados, as emoções humanas, em particular, são a principal motivação dos protagonistas, o que pode simbolizar rechaço à desumanização, seja na forma da tecnologia

47 Cf. MULVEY, Laura. Prazer Visual e Cinema Narrativo. In: XAVIER, Ismail (org). A Experiência do Cinema. Coleção Arte e Cultura, n. 5. Rio de Janeiro: Edições Graal, 1983. 
exacerbada em O Homem do Futuro, ou por meio do avanço do capital neoliberal em Branco Sai, Preto Fica. Essa aversão é mais explícita em O Homem do Futuro pela destruição da máquina do tempo, mas também se faz presente em Branco Sai, Preto Fica nas sutilezas dos mecanismos tecnológicos de controle da população. Tal característica já havia sido identificada por Elizabeth Ginway em outras obras nacionais de ficção científica; segundo ela, não é incomum que, ao mesmo tempo como forma de aceitação mas também resistência ao processo de modernização, os mitos brasileiros de identidade sejam projetados em uma sociedade do futuro como forma de oposição cultural à tecnologia percebida como ameaça (GINWAY, 2005a, p. 16).

Por fim, ao tentarmos enxergar em dois filmes brasileiros de ficção científica distintos, porém contemporâneos, a retomada do mito que prega o Brasil como a nação do futuro, chegamos a uma opinião similar à de Jameson em sua análise de Tubarão (SPILBERG, 1975), na qual o autor alega que reescrever o filme em termos de mito, para aprovação ou reprovação desse, contribui enfatizar sua dimensão utópica. Em O Homem do Futuro há concordância com a mitologia e a exaltação dessa como política a ser seguida; por outro lado, em Branco Sai, Preto Fica, a dimensão utópica é enfatizada para mostrar sua ineficiência. "País do futuro" por si só não nos parece ser mais um brado de união nacional, não apenas devido às mudanças nos sentimentos de identidade e pertencimento trazidas pela pós-modernidade, mas, principalmente, por ser necessário especificar a qual agenda político-econômica se refere, especialmente após o impeachment de 2016. Assim, ressaltamos a importância da análise de ficções científicas que podem conter não apenas realidades fantásticas, mas, soluções para esta. 


\section{REFERÊNCIAS ${ }^{48}$}

AGUILERA, Pedro. 3\%. Série televisiva.

ALLEN, L. David. No Mundo da Ficção Científica. São Paulo: Summus, 1974.

ALMEIDA, Abílio P. Nadando em Dinheiro. 1953. Filme cinematográfico.

ALMEIDA, Rodolfo et al. Da hiperinflação à estagflação: a economia desde 1991. Nexo Jornal, São Paulo, 02 mai. 2016. Disponível em:

$<$ https://www.nexojornal.com.br/grafico/2016/05/02/Da-hiperinfla\%C3\%A7\%C3\%A3o\%C3\%A0-estagfla\%C3\%A7\%C3\%A3o-a-economia-desde-1991>. Acesso em 20 out. 2018.

ALMEIDA, Rodrigo; MOURA, Luís Fernando (Orgs.). Brasil Distópico: catálogo. [Rio de Janeiro]: Ponte Produções, 2017. Catálogo de mostra cinematográfica. Disponível em: $<$ https://issuu.com/brasildistopico/docs/cata_logo_brasil_disto_pico $>$. Acesso em $18 \mathrm{dez}$. 2017.

ANDERSON, Benedict. Imagined Communities: reflections on the origin and spread of nationalism. Nova Iorque: Verso, 1983.

ANDRADE, Lucas de Melo. Romantismo e Ciência em O Doutor Benignus (1875): Augusto Emílio Zaluar e seu romance científico e instrutivo. 2014. 188 f. Dissertação (Mestrado em História) - Universidade Federal de Ouro Preto, Mariana, 2014. Disponível em: $<$ http://www.repositorio.ufop.br/bitstream/123456789/5693/1/DISSERTA \%C3\%87\%C3\%83O_RomantismoCi\%C3\%AanciaDoutor.pdf>. Acesso em 24 fev. 2018.

ARBEX JR, José. Rede Globo: teledramaturgia e poder sob ditadura. Nhengatu - Revista iberoamericana para Comunicação e Cultura contrahegemônicas, v. 2, n. 3, p. 1- 19. 2015.

ASIMOV, Isaac. Fundação: Trilogia. São Paulo: Hemus, 1975.

BARROS, Diana Luz Pessoa de. Teoria semiótica do texto. 4 ed. São Paulo: Parma, 2005.

BARROS, Luiz. Malandros em Quarta Dimensão. 1954. Filme cinematográfico.

BENTES, Ivana. The sertão and the favela in contemporary Brazilian film. In: Nagib, Lúcia (org.), The New Brazilian Cinema. Londres/ Nova Iorque: Tauris, 2003, p. 121 - 138.

BIELSCHOWSKY, Ricardo. Pensamento Econômico Brasileiro: o ciclo ideológico do desenvolvimentismo. Rio de Janeiro: Contraponto, 1995.

BLOCH, Ernest. The Principle of Hope. MIT Press, 1995.

48 De acordo com a Associação Brasileira de Normas Técnicas. NBR 6023 (2002). 
BRAGA, Ruy. A Política do Precariado: do populismo à hegemonia lulista. São Paulo: Boitempo, 2012.

. As jornadas de junho no Brasil: Crônica de um mês inesquecível. Observatório Social de América Latina, v. 8, p. 51-61, 2013. Disponível em:

$<$ http://biblioteca.clacso.edu.ar/clacso/osal/20131107012902/osal34.pdf\#page=52>. Acesso em 9 nov 2017.

Precariado e Sindicalismo no Brasil Contemporâneo: um olhar a partir da indústria

do call center. Revista Crítica de Ciências Sociais, n. 103, p. 25-52, 2014.

BRANT, Beto. O Invasor. 2002. Filme cinematográfico.

BOTTOMORE, Tom. Dicionário do pensamento marxista. Zahar, 1988.

CAMARGO, Maiara. Wagner Moura se encontra com ele mesmo em "O Homem do Futuro". O Estado de São Paulo, São Paulo, 2 set. 2011. Disponível em:

$<$ https://cultura.estadao.com.br/noticias/cinema,wagner-moura-se-encontra-com-ele-mesmoem-o-homem-do-futuro,767501>. Acesso em 23 jan. 2019.

CAMURATI, Carla. Carlota Joaquina, a princesa do Brasil. 1995. Filme cinematográfico.

CANELA, Carlos. Bailarina. 2001. Filme cinematográfico.

Dois Lados. 2003. Filme cinematográfico.

. O Homem da Cabeça de Papelão. 2007. Filme cinematográfico.

CARBONI, Bruno; PRETTO, Davi. Quarto de Espera. 2009. Filme cinematográfico.

CARDOSO, Ivan. Um Lobisomem na Amazônia. 2005. Filme cinematográfico.

CARRÉRA, Guilherme. Brasília amidst ruins: The sci-fi documentaries of Adirley Queirós and Ana Vaz. Aniki: Revista Portuguesa da Imagem em Movimento, v. 5, n. 2, p. 351 $377,2018$.

CAUSO, Roberto de S. Tupinipunk - Cyberpunk brasileiro. Papêra Uirandê Especial, n. 1, p. 5-11, 1996.

$\overline{\mathrm{UFMG}}, 2003$.

. Ficção Científica, Fantasia e Horror no Brasil: 1875 a 1950. Belo Horizonte:

CAVALCANTI, Alberto. Simão, o caolho. 1952. Filme cinematográfico.

CEVASCO, Maria Elisa. Para Ler Raymond Williams. São Paulo: Paz e Terra, 2001. 
CHAMPAGNATTE, Dostoiewski M. de O. Análise Crítica do Discurso Fílmico: caminhos para uma abordagem metodológica em análise fílmica. In: Congresso de Ciências da Comunicação da Região Sudeste, 19. 2014, Vila Velha. Anais Intercom. 2014, 13 p. Disponível em: <http://www.portalintercom.org.br/anais/sudeste2014/resumos/R43-18481.pdf $>$. Acesso em 27 dez. 2018.

COSTA, Iná Camargo; CEVASCO, Maria Elisa. Para a crítica do jogo aleatório dos significantes. In: JAMESON, Fredric. Pós-Modernismo: a lógica cultural do capitalismo tardio. São Paulo: Ática, p. 5-11, 1996.

CRUZ, Adriana I. G. et al. A Economia Brasileira: conquistas dos últimos 10 anos e perspectivas para o futuro. Banco Nacional de Desenvolvimento Econômico e Social, 2012. Disponível em:

$<$ https://www.bndes.gov.br/SiteBNDES/export/sites/default/bndes_pt/Galerias/Arquivos/ conhecimento/livro60anos_perspectivas_setoriais/

Setorial60anos_VOL1EconomiaBrasileira.pdf>. Acesso em 23 ago. 2018.

CUDDON, J. A. The Penguin Dictionary of Literary Terms and Literary Theory. 5 ed. London: Penguin, 1999.

DELLAPE, Santiago. Nada Consta. 2007. Filme cinematográfico.

DEO, Anderson. Apontamentos sobre o Imperialismo Brasileiro nos Governos Lula e FHC. Novos Rumos, v. 49, n.1, p. 127 - 138. Marília: Jan-Jun, 2012.

DEUTCH, Howard. A Garota de Rosa Shocking. 1986. Filme cinematográfico.

ECO, Umberto. Os Mundos da Ficção Científica. In:

Ensaios. Rio de Janeiro: Nova Fronteira, p. 166-172, 1989. . Sobre os Espelhos e Outros

EVANS, Arthur B. Nineteenth-Century SF. In: BOULD, Mark et al. (Orgs). The Routledge Companion to Science Fiction, p. 13 - 22. Londres: Routledge, 2009.

FALCÃO, João. A Máquina. 2005. Filme cinematográfico.

FERREIRA, Rachel Haywood. Latin America SF Discovers its Roots. Science Fiction Studies, vol. 34, n. 3, p. $432-462$.

FILHO, Kléber Mendonça. Recife Frio. Filme cinematográfico.

FLECK, Tomás; FACCINI, Gabriel; REZENDE, Tiago. Horizonte B. 2016. Série televisiva.

FIORAVANTI, Carlos. Doutor Benignus e os Extraterrestres. Pesquisa FAPESP, São Paulo, dez. 2016, p. 88 - 91. Disponível em: <http://revistapesquisa.fapesp.br/2016/12/16/doutorbenignus-e-os-extraterrestes/>. Acesso em 13 jul. 2018.

FIORIN, José Luiz. Elementos de Análise do Discurso. 14 ed. São Paulo: Contexto, 2009. 
FITTING, Peter. The Concept of Utopia in the Work of Fredric Jameson. Utopian Studies, v. 9, n. 2, p. 8-17, 1998. Disponível em: <http://www.jstor.org/stable/20719758>. Acesso em 22 jan. 2018.

FONSECA, Pedro Cezar Dutra. Gênese e Precursores do Desenvolvimentismo no Brasil. Pesquisa e Debate, v. 26, n. 2, p. 225-256, 2004.

FONSECA, Pedro C. D.; CUNHA, André M.; BICHARA, Julimar da S. O Brasil na Era Lula: retorno ao desenvolvimentismo? Nova Economia, v. 23, n. 2, p. 403-428, 2013.

GARCIA, Estevão. A Partir de Agora Vamos Falar em Espanhol. Revista Contracampo, v. 84, 5 p., 2007.

GIBSON, William F. Neuromancer. Tradução: Fábio Fernandes. 5 ed. São Paulo: Aleph, 2016.

GINWAY, M. Elizabeth. Ficção científica brasileira: mitos culturais e nacionalidade no país do futuro. São Paulo: Devir Livraria, 2005a.

A working model for analyzing third world science fiction: the case of Brazil.

Science Fiction Studies, p. 467- 494, 2005b. Disponível em:

$<$ http://www.jstor.org/stable/4241378>. Acesso em 26 fev. 2018.

GOMES, Wilson. La poética del cine y la cuestión del método en el análisis fílmico.

Significação: Revista de Cultura Audiovisual, v. 31, n. 21, p. 85-105, 2004.

HALL, Stuart. A Identidade Cultural na Pós-Modernidade. 12 ed. Tradução: Guacira Lopes Louro; Tomaz Tadeu da Silva. Rio de Janeiro: Lamparina, 2014.

HOLSTON, James. A Cidade Modernista: uma crítica de Brasília e sua utopia. São Paulo: Companhia das Letras, 1993.

HUGHES, John. Gatinhas e Gatões.1984. Filme cinematográfico.

INSTITUTO BRASILEIRO DE GEOGRAFIA E ESTATÍSTICA. SIS 2013: 74,1\% das mulheres de 25 a 29 anos que não estudam nem trabalham têm ao menos um filho. Disponível em: $<$ https://censo2010.ibge.gov.br/noticias-censo.html?

busca $=1 \& \mathrm{id}=1 \&$ idnoticia $=2526 \& \mathrm{t}=$ sis-2013-74-1-mulheres-25-29-anos-que-nao-estudamnem\&view=noticia $>$. Acesso em 10 mar. 2019.

JAMES, Edward. Utopias and antiutopias In: JAMES, Edward; MENDLESOHN, Farah (Orgs.). The Cambridge Companion to Science Fiction. Cambridge: Cambridge University Press, p. $219-230,2003$.

JAMESON, Fredric. O Inconsciente Político. São Paulo: Ática, 1992. 
Reificação e Utopia na Cultura de Massa. Tradução: João Roberto Martins Filho.

Crítica Marxista, n. 1, 26 p., 1994. Disponível em:

$<$ https://www.ifch.unicamp.br/criticamarxista/arquivos_biblioteca/artigo43Artigo1.1.pdf $>$. Acesso em 26 mar 2019.

Pós-modernismo: a lógica cultural do capitalismo tardio. Tradução: Maria Elisa Cevasco. São Paulo: Ática, 1996.

The Politics of Utopia. New Left Review, n. 25, 18p., 2004.

Archaeologies of the Future: the desire called utopia and other science fictions. Londres/Nova Iorque: Verso, 2005.

KELLNER, Douglas. A Cultura da Mídia. Bauru: EDUSC, 2001.

Media Spectacle. Londres: Routledge, 2003.

. O Apocalipse Social no Cinema Contemporâneo de Hollywood. MATRIZes, v. 10, n. 1, p. 13-28, 2016.

KOTCHEFF, Ted. Rambo: programado para matar. 1982.

LAMOSO, Lisandra Pereira. "Neodesenvolvimentismo" Brasileiro: implicações para a integração regional no âmbito do Mercosul. Sociedade \& Natureza, v. 24, n. 3, p. 391 - 403, 2012.

LEE, Spike. Faça a Coisa Certa. 1989. Filme cinematográfico.

LIMA JR, Walter. Brasil Ano 2000. 1969. Filme cinematográfico.

LIMAVERDE, J.; BARROS, Mino. Tempo Real. 2005. Filme cinematográfico.

LOPES, Débora. Para diretor de 'Branco Sai, Preto Fica', filme traz vingança simbólica contra violência policial. Opera Mundi, 8 abr. 2015. Disponível em:

$<$ https://operamundi.uol.com.br/samuel/40052/para-diretor-de-branco-sai-preto-fica-filmetraz-vinganca-simbolica-contra-violencia-policial>. Acesso em 23 jan. 2019.

LYRA, Bernadete. Aviso aos Navegantes: o fake está a bordo. In: FABRIS, Mariarosaria et al. (Orgs). Estudos de Cinema Socine Ano V, p. 181- 188, 2004. Disponível em: $<$ http://www.socine.org/wp-content/uploads/2015/11/V_Estudos_Socine.pdf $>$. Acesso em 31 jan 2018.

MACEDO, Watson. Carnaval em Marte. 1954. Filme cinematográfico.

MAGAlHÃES, Basílio de. Estudos da História do Brasil. São Paulo: Companhia Editora Nacional, 1940.

MANDEL, Ernest. O Capitalismo Tardio. São Paulo: Abril Cultural, 1992. 
MANGA, Carlos. O Homem do Sputinik. 1959. Filme cinematográfico.

MC Dodô. Bomba Explode na Cabeça. 2007. Digital.

MORAIS, Flávia. Acquária. 2004. Filme cinematográfico.

MARCELINO, Giovanna Henrique. Marxismo e Modernidade em Fredric Jameson. 2017. 205f. Dissertação (Mestrado em Sociologia) - Universidade de São Paulo, São Paulo, 2017. Disponível em: $<$ http://www.teses.usp.br/teses/disponiveis/8/8132/tde-16032018-131027/ptbr.php>. Acesso em 21 dez. 2018.

MARTINS, Raphael. FHC x Lula x Dilma: o vai - e - vem da aprovação dos presidentes. Revista Exame, 28 fev. 2016. Disponível em: $<$ https://exame.abril.com.br/brasil/fhc-x-lula-xdilma-o-vai-e-vem-da-aprovacao-dos-presidentes/>. Acesso em 25 jan. 2019.

MELZER, Patricia. Alien Constructions: science fiction and feminist thought. Austin: University of Texas, 2006.

MESQUITA, Cláudia. Memória contra utopia: Branco Sai, Preto Fica. In: XXIV Encontro da Compós, 24, 2015, Brasília. Anais....Brasília, 2015, 17 p. Disponível em:

$<$ http://www.compos.org.br/biblioteca/compos-2015-1a0eeebb-2a95-4e2a-8c4bc0f6999c1d34_2839.pdf>. Acesso em 26 mar. 2019.

MORAIS, Lecio; SAAD-FILHO, Alfredo. Da economia política à política econômica: o novo-desenvolvimentismo e o governo Lula. Revista de Economia Política, v. 31, n. 4, p. 507-527, 2011.

NAGIB, Lúcia. A Utopia no Cinema Brasileiro: matrizes, nostalgia, distopia. São Paulo: Cosac Naify, 2006.

NÁPOLI, Marco. Céus de Fuligem. 2005. Filme cinematográfico.

NOGUEIRA, Carlos Eduardo. Zigurate. 2009. Filme cinematográfico.

OBSERVATÓRIO Brasileiro do Cinema e do Audiovisual. Resultado do Cinema Brasileiro - 2009 a 2017. 2018a. Disponível em: $<$ https://oca.ancine.gov.br/resultados-do-cinemabrasileiro-2009-2017>. Acesso em 06 fev. 2019.

Listagem de filmes brasileiros com mais de 500.000 espectadores 1970 a 2017.

2018b. Disponível em:

$<$ https://oca.ancine.gov.br/sites/default/files/repositorio/pdf/2105_0.pdf $>$. Acesso em 30 set. 2018.

OLIVEIRA, Tony Marcelo Gomes de. Marcas do Processo de Formação do Espaço Urbano de Brasília pela Ótica da Erradicação de Favelas. Universitas Humanas, Brasília, v. 5, n. 1-2, p. 49-76, jan. - dez. 2008. 
PAVIANI, Aldo. A construção injusta do espaço urbano. In: PAVIANI, Aldo (Org.). A Conquista da Cidade: movimentos populares em Brasília. Brasília: Editora da UnB, 1991. p. 115-142.

PIASSI, Luís Paulo de Carvalho. Interfaces entre fantasia e ciência - Um estudo semiótico do filme "2001: uma Odisseia no Espaço" como modelo de interpretação em perspectiva educacional. 2012. 204 f. Tese (livre docência). Universidade de São Paulo, USP, São Paulo, 2012. Disponível em: $<$ http://www.teses.usp.br/teses/disponiveis/livredocencia/100/tde29082016-161259/pt-br.php>. Acesso em 02 out. 2018.

PIASSI, Luís Paulo; PIETROCOLA, Maurício. Ficção científica e ensino de ciências: para além do método de 'encontrar erros em filmes'. Educação e Pesquisa, v. 35, n. 3, p. 525-540, 2009.

PIRES, Roberto. Abrigo Nuclear. 1981. Filme cinematográfico.

QUEIRÓS, Adirley. A Cidade é uma Só?. 2012. Filme cinematográfico.

Branco Sai, Preto Fica. 2014. Filme cinematográfico.

Canal E Cultura: Branco Sai, Preto Fica. Entrevista em vídeo. CANAL E, publicado em 3 out. 2014. Disponível em: < https://www.youtube?.com/watchv=Z1oG-_gXhC0>. Acesso em 08 dez. 2018.

REDE GLOBO. Debate Collor x Lula. Memória Globo. Erros. [20--]. Disponível em: $<$ http://memoriaglobo.globo.com/erros/debate-collor-x-lula.htm>. Acesso em 18 mar. 2019.

O Clone. 2001. Novela televisiva.

A Fórmula. 2017. Série televisiva.

. Tempos Modernos. 2018. Novela televisiva.

ROBERTS, Adam. Science Fiction. Londres: Routledge, 2000.

SAMPAIO, Silveira. Uma Aventura aos 40. 1947. Filme cinematográfico.

SANTOS, Éder. Deserto Azul. 2013. Filme cinematográfico.

SALLES, Walter. Central do Brasil. 1999. Filme cinematográfico.

SARGENT, Lyman Tower. The Three Faces of Utopianism Revisited. Utopian Studies, vol. 5, n. 1 , p. $1-37,1994$.

SAUSSURE, Ferdinand. Curso de Linguística Geral. São Paulo: Pensamento - Cultrix, 2001. 
SCHWARZ, Bill. Conservatism, nationalism and imperialism. In: Donald, James; Hall, Stuart (Orgs). Politics and Ideology. Open University Press, p. 106., 1986.

SEVERIEN, Pedro. O Homem Planta. 2011. Filme cinematográfico.

SGANZERLA, Rogério. O Bandido da Luz Vermelha. 1968. Filme cinematográfico.

SHELLEY, Mary Wollstonecraft. Frankenstein, ou O Prometeu Moderno. 1 ed. Tradução: Christian Schwartz. São Paulo: Penguin, 2017.

SINGER, André Vitor. Cutucando Onças com Varas Curtas: o ensaio desenvolvimentista no primeiro mandato de Dilma Rousseff (2011-2014). Novos Estudos, São Paulo, n. 102, p. 43$71,2015$.

. A (Falta de) Base Política para o Ensaio Desenvolvimentista. In: SINGER, André; LOUREIRO (Orgs.). As Contradições do Lulismo: a que ponto chegamos? 1 ed. São Paulo: Boitempo, p. $21-54,2016$.

SINGER, André; LOUREIRO, Isabel. Elementos para uma cartografia do desenvolvimento lulista. In: (Orgs.). As Contradições do Lulismo: a que ponto chegamos? 1 ed. São Paulo: Boitempo, p. 9 - 19, 2016.

SKORUPA, Francisco Alberto. Viagem às Letras do Futuro: extratos de bordo da ficção científica brasileira: 1947-1975. 256f. Dissertação (Mestrado em Letras) - Universidade Federal do Paraná, Curitiba, 2001. Disponível em:

$<$ https://www.acervodigital.ufpr.br/bitstream/handle/1884/24261/Dissertacao\%20mestrado \%20Historia-2002.pdf? sequence=1>. Acesso em 9 ago. 2018.

SPILBERG, Steven. Tubarão. 1975. Filme cinematográfico.

STABLEFORD, Brian. Science Fiction Before the Genre. In: JAMES, Edward; MENDLESOHN, Farah (Orgs.). The Cambridge Companion to Science Fiction, Cambridge: Cambridge University Press, p. 15 - 31, 2003.

STAM, Robert. Introdução à Teoria do Cinema. Campinas: Papirus, 2003.

STUART, Adriano. Os Trapalhões na Guerra dos Planetas. 1978. Filme cinematográfico.

SUPPIA, Alfredo Luiz Paes de Oliveira. Notas para uma História Crítica da Ficção Científica no Cinema Brasileiro. Caligrama. v. 2, n. 2, 13 p., 2006.

Limite de Alerta! Ficção Científica em Atmosfera Rarefeita: uma introdução ao estudo da FC no cinema brasileiro e em algumas cinematografias off-Hollywood. 447 p., Tese (Doutorado em Multimeios) - Universidade Estadual de Campinas, Campinas, 2007.

Disponível em: $<$ http://repositorio.unicamp.br/handle/REPOSIP/285029>. Acesso em 11 out. 2017. 
SUPPIA, Alfredo L. P. O.; GOMES, Paula. Por um Cinema Infiltrado: entrevista com Adirley Queirós e Maurílio Martins a propósito de Branco Sai, Preto Fica (2014). Revista Digital de Cinema Documentário. n. 18, p. 389 - 413, 2015.

SUVIN, Darko. Metamorphoses of Science Fiction: on the poetics and history of a literary genre. Yale University Press, 1979.

Metamorfosis de la ciencia ficción: sobre la poética y la historia de un género literario. 1 ed. Tradução: Federico Patán Lopez. Cidade do México: Fondo de Cultura Económica, 1984.

TANKO, J. B. O Trapalhão no Planalto dos Macacos. 1976. Filme cinematográfico.

THE ECONOMIST. Brazil takes off: now the risk for Latin America's great sucess is hubris. Londres: The Economist, nov, 2009. Editorial. Disponível em:

$<$ https://www.economist.com/leaders/2009/11/12/brazil-takes-off $>$. Acesso em 26 mar. 2019.

THOMAS, Daniela; Walter, Salles. O Primeiro Dia. 1998. Filme cinematográfico.

TORRES, Cláudio. O Homem do Futuro. 2011. Filme cinematográfico.

ULTRAJE a Rigor. Inútil. 1985. Música.

VALENTINI, R. Deep Space Worms - os horrendos vermes do espaço profundo. 2008.

Filme cinematográfico.

VENTURI, Toni. Latitude Zero. 2000. Filme cinematográfico.

VERNE, Julio. A Volta ao Mundo em 80 Dias. 2 ed. Tradução: Walcyr Carrasco. Moderna, 2012.

VIEIRA, João Luiz. From High Noon to Jaws: Carnival and Parody in Brazilian Cinema. In: JOHNSON, Randal e STAM, Robert. Brazilian Cinema. Columbia University Press, 1995.

WELLS, H. G. A Máquina do Tempo. São Paulo: Tecnoprint, 1972.

WRIGHT, Ronald. Uma Breve História do Progresso. Trad: Carolina Araújo. Rio de Janeiro: Record, 2007.

ZALUAR, Augusto Emílio. O Doutor Benignus. Rio de Janeiro: Editora da UFRJ, 1994

ZEMECKIS, Robert. De Volta para o Futuro. 1985. Filme cinematográfico.

ZWEIG, Stefan. Brasil, país do futuro. Trad: Odilon Gallott. Edição eletrônica: Ed. Ridendo Castigat Mores, 2001. 